Portland State University

PDXScholar

Spring 8-24-2016

\title{
Watershed Response to Climate Change and Fire- Burns in the Upper Umatilla River Basin Using the Precipitation Runoff Modeling System
}

Kimberly Crystal Yazzie

Portland State University

Follow this and additional works at: https://pdxscholar.library.pdx.edu/open_access_etds

Part of the Climate Commons, and the Water Resource Management Commons Let us know how access to this document benefits you.

\section{Recommended Citation}

Yazzie, Kimberly Crystal, "Watershed Response to Climate Change and Fire-Burns in the Upper Umatilla River Basin Using the Precipitation Runoff Modeling System" (2016). Dissertations and Theses. Paper 3127.

https://doi.org/10.15760/etd.3123

This Thesis is brought to you for free and open access. It has been accepted for inclusion in Dissertations and Theses by an authorized administrator of PDXScholar. Please contact us if we can make this document more accessible: pdxscholar@pdx.edu. 
Watershed Response to Climate Change and Fire-Burns in the Upper Umatilla River Basin

Using the Precipitation Runoff Modeling System

\author{
by \\ Kimberly Crystal Yazzie
}

A thesis submitted in partial fulfillment of the requirements for the degree of

\author{
Master of Science \\ in \\ Environmental Science and Management
}

Thesis Committee:

Joseph Maser, Chair

Heejun Chang

John Risley

Scott Burns

Portland State University

2016 
(C) 2016 Kimberly Crystal Yazzie 
Abstract

This study provides an analysis of watershed response to climate change and forest fire impacts, to better understand the hydrologic budget and inform water management decisions for present and future needs. The study site is $2,365 \mathrm{~km}^{2}$, located in the upper Umatilla River Basin (URB) in northeastern Oregon. The Precipitation Runoff Modeling System, a distributed-parameter, physical-process watershed model, was used in this study. Model calibration yielded a Nash Sutcliffe Model Efficiency of 0.73 for both calibration (1995-2010) and validation (2010-2014) of daily streamflow. Ten Global Climate Models using Coupled Model Intercomparison Project Phase 5 experiments with Representative Concentration Pathways 4.5 and 8.5 (RCP), were used to observe hydrologic regime shifts in the 2020s, 2050s, and 2080s. Mean center timing of flow occurs earlier in the year in both pre- and post-fire conditions, where there are increased winter flows and decreased summer flows throughout the $21^{\text {st }}$ century. Change in temperature and percent change in precipitation is more variable in the summer than winter increasing over time, with a slight decrease in winter precipitation in the 2080s in RCP 8.5. Temperature increases $1.6^{\circ} \mathrm{C}$ in RCP 4.5 and $3.3^{\circ} \mathrm{C}$ in RCP 8.5 by the end of the $21^{\text {st }}$ century. The ratio of Snow Water Equivalent to Precipitation decreases $96 \%$ in the 2080s in RCP 8.5 before forest cover reduction, and decreases $90-99 \%$ after forest cover reduction. Potential basin recharge and the base-flow index are both sustained throughout the $21^{\text {st }}$ century with slight declines before forest cover reduction, with an increase in basin recharge and increase in base-flows in the 2080s after fire-burns. However, the 
simulated sustained base-flows and area-weighted basin recharge in this study, do not take into account the complex geologic structure of the Columbia River Basalt Group (CRBG). A more robust characterization and simulation of URB aquifer recharge would involve coupling the PRMS model with a groundwater model in a future study. Although groundwater recharge in the CRBG in the URB is not well understood, the long-term decline of groundwater storage presents a serious environmental challenge for the Confederated Tribes of the Umatilla Indian Reservation and communities in the URB. 
I dedicate this thesis to my parents, Kee and Esther, as this endeavor would not have been possible without their unwavering support and enthusiasm.

A sincere thank you to my committee members for their unrelenting advice, patience and guidance: Joseph Maser for helping me navigate PSU, Heejun Chang for his wealth of knowledge and providing lab space, John Risley for his expertise in watershed modeling, and Scott Burns for inspiring scientific inquiry. I have much gratitude for the NW NARCH program, Intertribal Timber Council, and the Geology Foundation for research funding support. Thank you to Katherine Hegewisch at University of Idaho for consultation on climate data; Marshall Gannett for USGS introductions; Snow for being my sounding board. And thank you to Kate Ely for setting the backdrop for my study site and hosting me during my field visits to Pendleton, OR. Thank you to faculty and fellow students within the School of the Environment for interactions that have enriched my tenure at PSU. Last but not least, thank you and much fondness to Mat Dorfman for being at my side throughout this whole process. 
Contents

ABSTRACT

ACKNOWLEDGEMENTS .................................................................................... ii

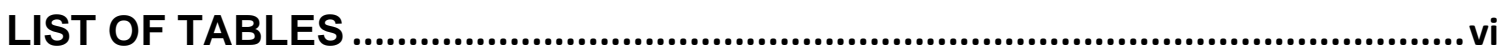

LIST OF FIGURES ..............................................................................................

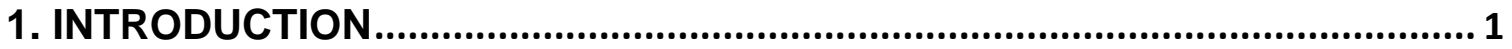

2. STUDY AREA

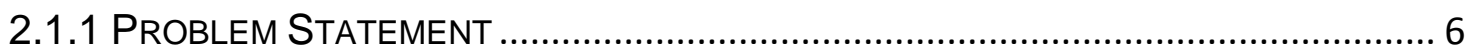

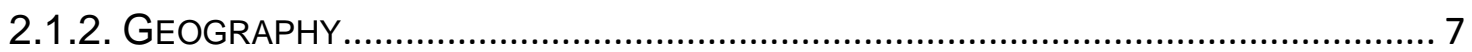

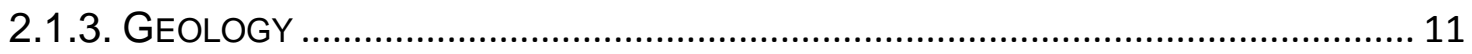

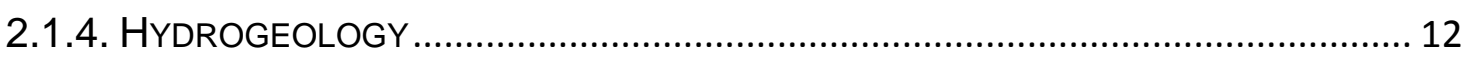

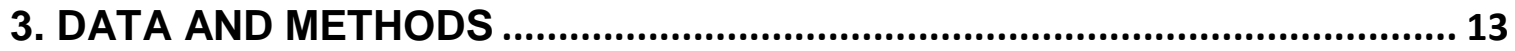

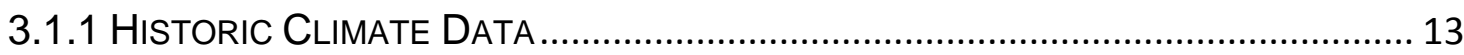

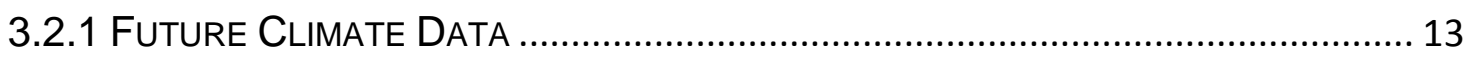

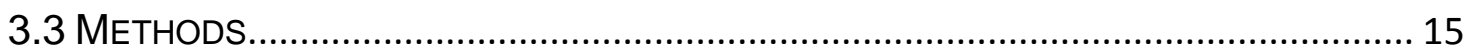

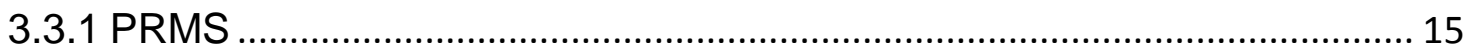

3.3.2 INDICATORS FOR DETECTING CLIMATE CHANGE IMPACT ................................. 18

3.3.3 GENERATION OF HYDROLOGIC RESPONSE UNITS (HRU) ............................... 19

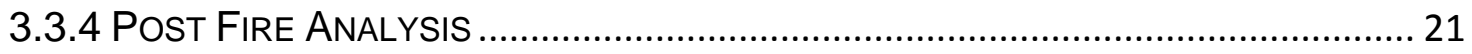

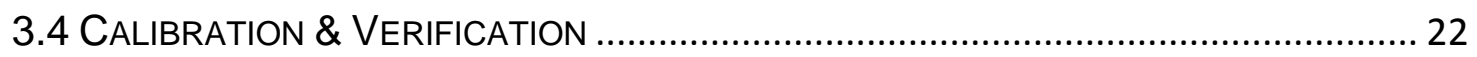

3.4.1 Model PeRformance EVAluation ........................................................ 25

4. RESULTS

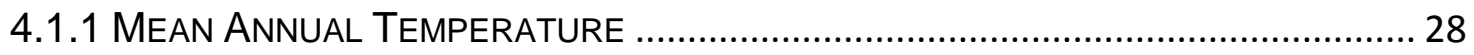

4.1.2 Change in Temperature and Percent Change in Precipitation ............. 29

4.1.3 Seasonal Change in Temperature and Percent Change in

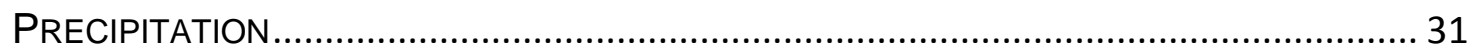

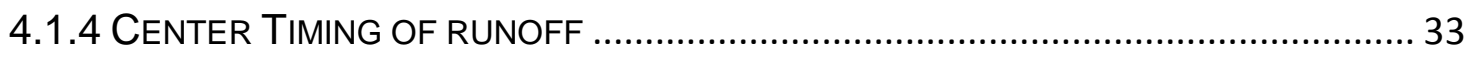

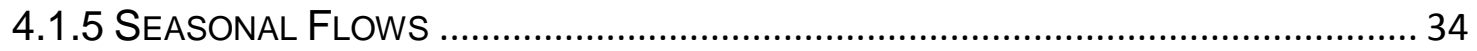

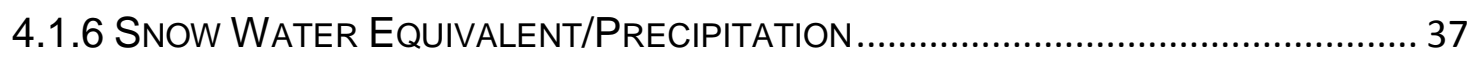

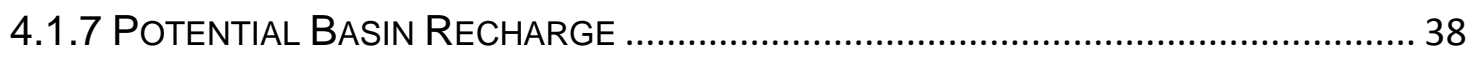

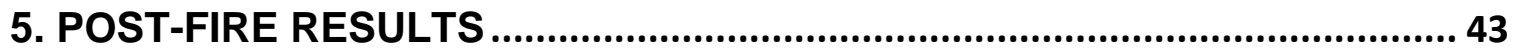

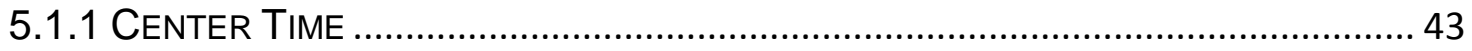

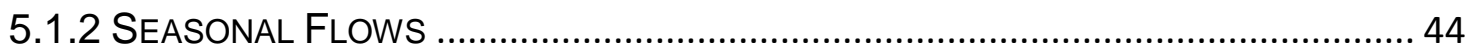

5.1.3 SNOW WATER EQUIVALENT/PRECIPITATION..................................................... 47 


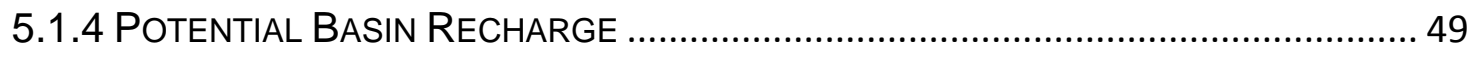

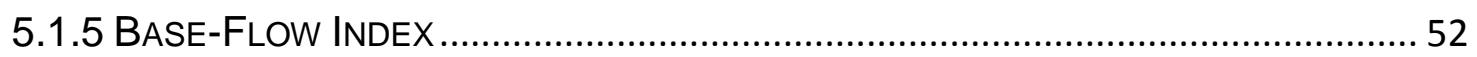

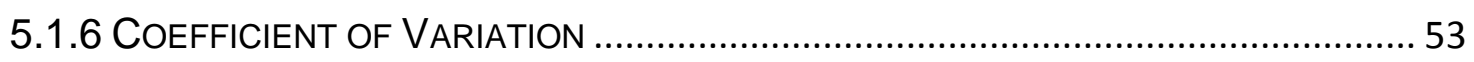

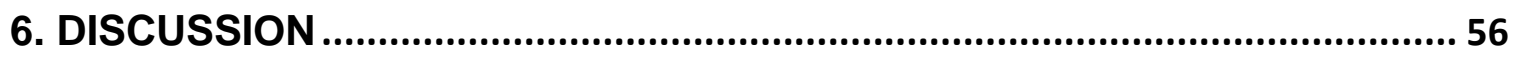

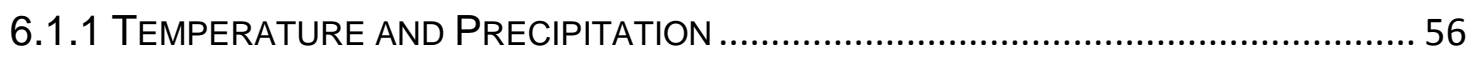

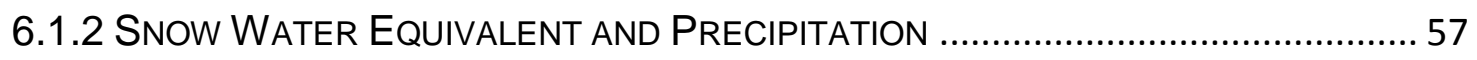

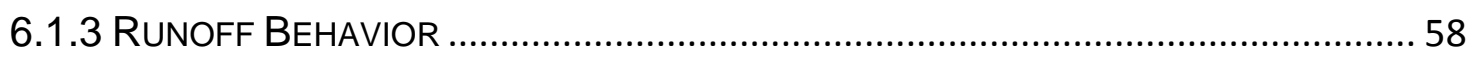

6.1.4 Potential Basin RECHARgE \& BASE-FLOW .............................................. 59

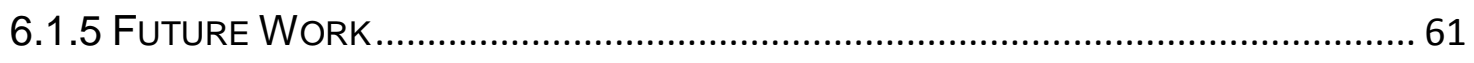

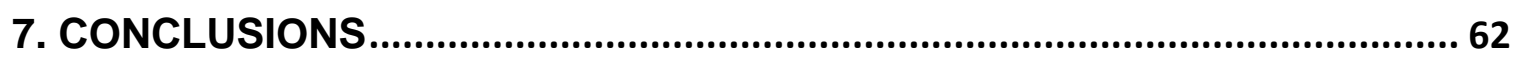

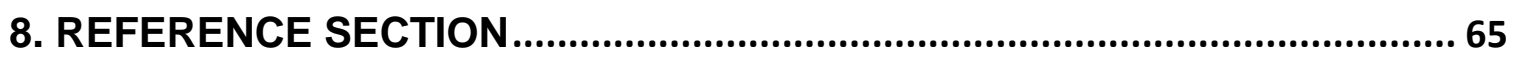

APPENDIX A: SUMMARY OF STATISTICAL ANALYSES COMPARING KEY CLIMATE INDICES BEFORE FOREST COVER REDUCTION ........................ 80

APPENDIX B: SUMMARY OF STATISTICAL ANALYSES COMPARING KEY CLIMATE INDICES AFTER FOREST COVER REDUCTION ........................... 81

APPENDIX C: COMPARISON OF MODEL PERFORMANCE .......................... 82 
Table 1: Datasets, models and tools used for analysis, including data derived. . 15

Table 2: Model parameters changed for forest cover reduction............................ 22

Table 3: Global Climate Models used in this study............................................... 22

Table 4: Tabulated summary of final parameters used for calibration. ................. 24

Table 5: Tabulated summary of statistics used for calibration and validation. ..... 27

Table 6: Change in temperature $(T)$ and percent change in precipitation $(P)$...... 31

Table 7: Minimum and maximum values of change in seasonal temperature ( $T$ ) and percent change in precipitation $(\mathrm{P})$ in comparison to historical records....... 32

Table 8: Mean CT before forest cover reduction. ................................................ 34

Table 9: Percent change of seasonal flows in comparison to historical conditions.

Table 10: Percent change of SWE/P before forest cover reduction. ..................... 38

Table 11: Cumulative mean and percent change in basin recharge. ................... 41

Table 12: Mean monthly and perecent change in basin recharge. ...................... 42

Table 13: Mean CT before and after forest cover reduction in the RCP 8.5 scenario.

Table 14: Percent change of seasonal flows before and after forest cover reduction in the RCP 8.5 scenario (WTR=Winter; SMR=Summer).

Table 15: Ratio of snow water equivalent to precipitation before and after forest cover reduction in the RCP 8.5 scenario.

Table 16: Percent change of mean basin recharge before and after forest cover reduction.

Table 17: Peak mean basin recharge and peak month

Table 18: Base-flow Index (BFI) and percent change before and after forest cover reduction. 
List of Figures

Figure 1: The study site is $2,365 \mathrm{~km} 2$ in the upper Umatilla River Basin in northeastern Oregon. 10

Figure 2: Photos of the URB upstream in the Blue Mountains (L), hilly grasslands at mid-elevation (M), and downstream near the City of Pendleton (R). 11

Figure 3: Schematic diagram of a watershed and its meteorological inputs simulated by PRMS (Markstrom et al., 2008) ...................................................... 17

Figure 4: Workflow of data input, PRMS calibration, and data output................... 18 Figure 5: Discretization of $107 \mathrm{HRUs}$ included using watershed subbasins $(\mathrm{T})$,

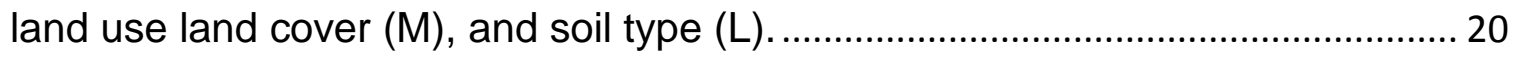

Figure 6: Historical and simulated mean monthly streamflow (1995-2010)........ 27 Figure 7: Annual mean temperature for all GCMs for RCP 4.5 with the ensemble mean in black. 28

Figure 8: Annual mean temperature for all GCMs for RCP 8.5 with ensemble mean in black.

Figure 9: Change in temperature and annual percent change in precipitation in comparison to historical conditions for all GCMs. 30

Figure 10: Change in seasonal temperature $(T)$ and percent change in precipitation $(\mathrm{P})$ for all GCMs in comparison to historical records. 32

Figure 11: Ensemble mean basin CT for RCP 4.5 and RCP 8.5 scenarios......... 34 Figure 12: Change in basin mean runoff for summer and winter flow ................... 36 Figure 13: Ensemble mean of the ratio of snow water equivalent to precipitation.

Figure 14: Cumulative ensemble mean basin recharge. 40 Figure 15: Ensemble mean for monthly basin recharge in the RCP 4.5 scenario.

Figure 16: Ensemble mean for monthly basin recharge in the RCP 8.5 scenario42 Figure 17: Mean Center Timing of flow for MIROC5 and HadGEM2-ES in the RCP 8.5 scenario before and after forest cover reduction. 44

Figure 18: Seasonal flows for MIROC5 and HadGEM2-ES in the RCP 8.5 scenario before and after forest cover reduction. 46

Figure 19: Ratio of snow water equivalent to precipitation before and after forest cover reduction in the RCP 8.5 scenario.................................................................... 48

Figure 20: Mean basin recharge before and after forest cover reduction............. 50 Figure 21: Mean basin monthly recharge for MIROC5 before and after forest cover reduction.

Figure 22: Mean basin monthly recharge for HadGEM2-ES before and after forest cover reduction. 
Figure 23: Coefficient of Variation of seasonal flows before forest cover

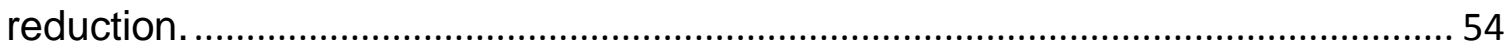
Figure 24: Coefficient of Variation of seasonal flows after forest cover reduction. 55 


\section{Introduction}

Anthropogenic influences on climate change have shifted the spatial and temporal distribution of water resources worldwide, requiring changes in the management of surface- and ground-water resources (Oki and Kanae, 2006; Kundzewicz et al. 2007; Praskievicz \& Chang, 2011). Quantifying recharge and streamflow response to climate change is an early step to developing long-term water resource management plans to increase understanding of the global energy balance in a hydrologic regime to improve adaptive capacity (Qi et al., 2009; Waibel et al., 2013). Identifying trends in basin runoff is important due to the strong effects on water and energy demands (Jung \& Chang, 2011) that may have important ecological implications.

A marked shift in global mean surface temperature in the $20^{\text {th }}$ century has been widely cited as an indicator of climate change and its direct relationship to changes in the global energy budget (Hamlet \& Lettenmaier, 2007; Abatzoglou, 2014). Climate change impacts in the Pacific Northwest include the shifts in the magnitude and timing of runoff (Chang and Jung, 2010; Elsner et al., 2010, Hamlet et al., 2010; Surfleet et al. 2012), reduced proportion of precipitation falling as snow in sub-montane regions (Knowles et al., 2006; Abatzoglou 2011), decreases in snow water equivalent (Mote et al., 2005; Mastin et al., 2011), and an increase in frequency and intensity of floods and droughts (Mote et 
al., 2003; Jung and Chang, 2011b; Surfleet et al. 2012). Further, changes in snowpack have affected the timing of runoff (Stewart et al., 2005; Hamlet et al. 2006; Hamlet \& Lettenmaier, 2007;Barnett et al. 2008; Vano et al. 2015) and soil moisture recharge (Hamlet \& Lettenmaier, 2007), increasing cool season flows and decreasing warm season flows (Hamlet, 2010).

The earth's water and energy systems, including solar radiation and temperature, can be characterized by a watershed model to guide watershed assessments and natural resource management in a changing climate. The application of watershed models can integrate biosystems, geochemistry, atmospheric sciences and coastal processes (Singh \& Frevert, 2006) to analyze trends in floods and droughts (Christensen et al. 2004; Park \& Markus, 2014), streamflow and water quality (Raines et al. 2002; Hutchinson et al., 2013), agriculture and sediment loading (Chang et al., 2001; Lambrechts et al., 2014), and land use change (Choi 2008; Praskievicz \& Chang, 2011).

Recharge rates vary widely in space and time, and are difficult to measure directly (Battin et al. 2007; Healy 2010; Chang and Jung, 2010; Waibel et al. 2013). At the regional scale, recharge has been estimated in the Columbia River Basin (Vaccaro 1986; Bauer \& Vaccaro, 1987; Hansen et al. 1994; Burns et al. 2012), while no studies have been completed at the local scale in the Umatilla River Basin (URB) nor have the effects of fire on the hydrologic regime been analyzed in the URB by a surface-model, making this study unique. 
The Precipitation Runoff Modeling System (PRMS) was chosen due to its application to evaluate various combinations of climate data and land use on flow regimes; use for basin-scale analysis (Cherkauer, 2004; Surfleet et al., 2012); offers a rigorous simulation of the subsurface system; ability to quantify groundwater recharge (Hunt et al., 2001; Steuer \& Hunt, 2001; Cherkauer, 2004; Vaccaro \& Olsen, 2007), evaluate interdecadal variability of climate change impacts (Chang \& Jung, 2010; Jung \& Chang, 2011; Markstrom et al., 2012), and evaluate land cover change (Qi et al., 2009; Vynee et al., 2010; Viger et al., 2011).

Three research questions will be explored to characterize the hydrologic regime in the URB:

(1) How does the hydrologic regime change seasonally and annually, i.e. water budget variables, in response to climate change in the 2020s, 2050s and 2080s in comparison to historical conditions?

(2) What are the effects of land cover change after fire-burns on basin runoff and other components of the water budget in the 2050s, and 2080s in comparison to historical conditions?

(3) Which water budget components (e.g., seasonal runoff, snow water equivalent) are sensitive to changes in climate and could potentially be considered in water resource management for climate adaptation planning? 
The Columbia River Basin has been researched extensively (Drost et al., 1986; Vaccaro 1986; Tolan et al., 1987; Bauer \& Vaccaro, 1990; Chang et al., 2013), including the lower URB due to Critical Groundwater Areas and Ground Water Limited Areas with long-term decline in groundwater (Sceva, 1966; Oberlander \& Miller, 1981; Burns et al., 2012). The upper URB in particular, is largely understudied. The aquifer system covers $113,959 \mathrm{~km}^{2}$, including southeastern Washington, northeastern Oregon, and western Idaho. The United States Geological Survey (USGS) in a study of the Columbia Plateau Regional Aquifer System (CPRAS) found significant groundwater-level declines (Burns et al., 2012) and in the upper URB, declines have been estimated to be $107 \mathrm{~cm} / \mathrm{yr}$ (Wallulis, 1995). Groundwater recharge in the URB has been estimated to range from 10,000 to 64,000 ac-ft/yr (OWRD 1988; Ely, 2001). Previous studies estimated recharge for predevelopment conditions in the region to be $6.90 \mathrm{~cm} / \mathrm{yr}$, and in the $1980 \mathrm{~s}, 10.80 \mathrm{~cm} / \mathrm{yr}$, an increase due to irrigation (Hansen et al., 1994). Studies have found significant recharge to occur with direct infiltration of interflow zones in the Columbia River Basalt Group (CRBG) at or near the surface or when directly connected to surface water (Newcomb,1959, 1969; Davies-Smith et al., 1988; US DOE, 1988; Lindberg, 1989; Hansen et al., 1994; Tolan et al., 2009).

As for fire-burns, studies indicate that after a wildfire watershed systems often have increased runoff due to decreased canopy interception, reduced vegetation cover, and changed chemical and physical properties of soil (Moody \& Martin, 2001; Viera et al, 2015). The infiltration rate after a wildfire has been 
observed to decrease two to seven-fold (Cerda, 1998; Martin \& Moody, 2001; Moody \& Martin, 2001) and cause erosion from overland flow (Robichaud, 2005). Changes in peak discharges are more apparent than changes in annual runoff (Moody \& Martin, 2001), where in some places, peak runoff increases by two orders of magnitude (Rulli et al, 2006, 2013; Terranova et al, 2009). Analysis of the effects of forest cover reduction can provide information on post-fire rehabilitation treatments on hill slopes to address increased runoff, decreased infiltration rates, and erosion (Robichaud, 2005), and to predict the magnitude of floods after a fire where the frequency and magnitude of peak discharge events are affected (Moody \& Martin, 2001). 


\section{Study Area}

\subsubsection{Problem Statement}

The upper Umatilla River Basin (URB) is largely understudied with a lack of understanding the surface and groundwater interactions and the effects of climate change on the hydrologic regime. Groundwater has been the primary supply of water throughout the $20^{\text {th }}$ century for domestic, municipal, and agricultural needs with over 1,100-1,200 wells in the upper URB, and 700-800 wells on the Umatilla Indian Reservation (UIR) (Ely, 2001). In the 1920s, the Umatilla Reclamation Project blocked the return of anadromous fish resulting in a steep decline of salmon return. There are four Oregon Water Resources Department Groundwater Restricted Areas in the lower URB with long-term groundwater declines (Burns et al., 2012; OWRD, 2012). In 1988, the Umatilla Basin Project Act resulted in a bucket-for-bucket exchange of Umatilla River water for Columbia River water, which improved flows to restore salmonid and steelhead populations (The Umatilla Local Advisory Comm., 2012). Burns et al. (2012) indicate water levels have declined 30-91 m since 1970 in some of the deeper CRBG aquifers where the physical characteristics of basalt, depositional environment, folding and faulting impede groundwater flow.

Understanding groundwater and surface-water interactions is important to sustainable water resources management in the study area and region.

Disproportionate impacts of climate change in tribal communities requires climate adaptation planning where some tribes are developing adaptation plans and few have implemented climate change into forest management plans (IFMAT, 2013). 
The cultural value of water cannot be understated, making it more important to protect natural resources vital to the Confederated Tribes of the Umatilla Indian Reservation (CTUIR). The tribes ceded more than $25,899 \mathrm{~km}^{2}$ to the United States in the Treaty of 1855 , reserving their rights to fish, hunt and gather traditional foods on ceded lands (CUJ, 2012). CTUIR implemented the protection of first foods, including water, salmon, deer, cous, and huckleberry into natural resource management as a form of self-determination for environmental equity and tribal resilience, (Ely, 2001; Jones et al, 2008). First Foods are the "minimum ecological products necessary to sustain CTUIR culture" (Jones et al., 2008). This study can help support protection of cultural and ecosystem services in the study area by providing runoff trends throughout the $21^{\text {st }}$ century for climate adaptation planning.

\subsubsection{Geography}

The study site is on the Columbia Plateau in the Yakima Fold Belt in the URB in northeastern Oregon (Burns et al., 2012). It is home to four informal physiographic subprovinces, each with its unique groundwater characteristics, including the Yakima Fold Belt, Blue Mountains, Palouse Slope subprovinces, and the Clearwater Embayment (Burns et al., 2012). The study site is $2,365 \mathrm{~km}^{2}$ in area, bounded on the east by the Blue Mountains and Umatilla National Forest within the Upper Grand Ronde Subbasin, on the South by the North Fork John Day Watershed Subbasin, on the west by the Willow River Watershed subbasin, on the North by the Middle-Columbia-Lake Wallula subbasin and to the 
northeast, the Walla Walla subbasin (Fig. 1). A significant portion of the UIR, 647 $\mathrm{km}^{2}$, is within the study site boundaries (Fig. 1).

Originating in the Blue Mountains, the Umatilla River is a gravel-bed channel system with a multi-channel pattern (Hughes, 2008). It is largely groundwater fed, according to baseflow estimates based on a seepage run that determined $70-80 \%$ of groundwater contributions to surface water, providing flow in the summer months (Ely et al, 2001, 2012). The upper basin is approximately $14 \%$ in drainage area but supplies $40-50 \%$ of the average flow to the Umatilla River (US Forest Service, 2001; Forest Management Plan, 2010). The Umatilla River is a $145 \mathrm{~km}$ reach that enters the Columbia River, which further extends 2,000 km before it exits into the Pacific Ocean. The Umatilla River has eight major tributaries, including the North and South Forks, and Meacham Creek, which are in the study area. In the mid-basin, Wildhorse, Tutuilla, McKay, and Birch creeks join the main stem, and in the lower basin, Butter Creek joins the Umatilla River (CTUIR, 2010).

The basin is mostly semiarid, located east of the Cascades in the rain shadow. It receives $12.7 \mathrm{~cm}$ in annual precipitation in the lowlands and $127 \mathrm{~cm}$ in the highlands in the Blue Mountains (Ely, 2001). The mean annual precipitation for the Columbia Plateau is $43 \mathrm{~cm}$ (Kahle et al, 2011; Burns et al, 2012). Elevation in the URB ranges from 82-1,676 meters in the lowlands to the highlands (Ely, 2001). The study site encompasses $55.1 \%$ coniferous tree cover, $0.1 \%$ deciduous and mixed tree cover, $21.7 \%$ shrub cover, $21.8 \%$ grass, and 
$1.3 \%$ bare soil (Homer et al, 2015). The most common types of forest type are grand fir and Douglas fir, followed by ponderosa pine and lodgepole pine, at 26\%, 25\%, 17\% and 6\% cover, respectively (Christensen et al, 2007). U.S. Forest Service owns $13 \%$ of the land in the subbasin, while CTUIR manages $12 \%$, urban areas comprise $6.0 \%$ and the rest of the land is shared by agriculture and rangeland uses (Vynee et al, 2010). Contrary to coniferous tree cover in the Blue Mountains, mid-elevation areas include grasslands and rolling hills, and desert vegetation downstream (Fig. 2). Annual water use on the UIR in 2005 includes $52 \%$ for irrigation, $30 \%$ for municipal needs, $18 \%$ for domestic needs, and $0 \%$ for pollution abatement (Technical Report, CTUIR, 2007). 


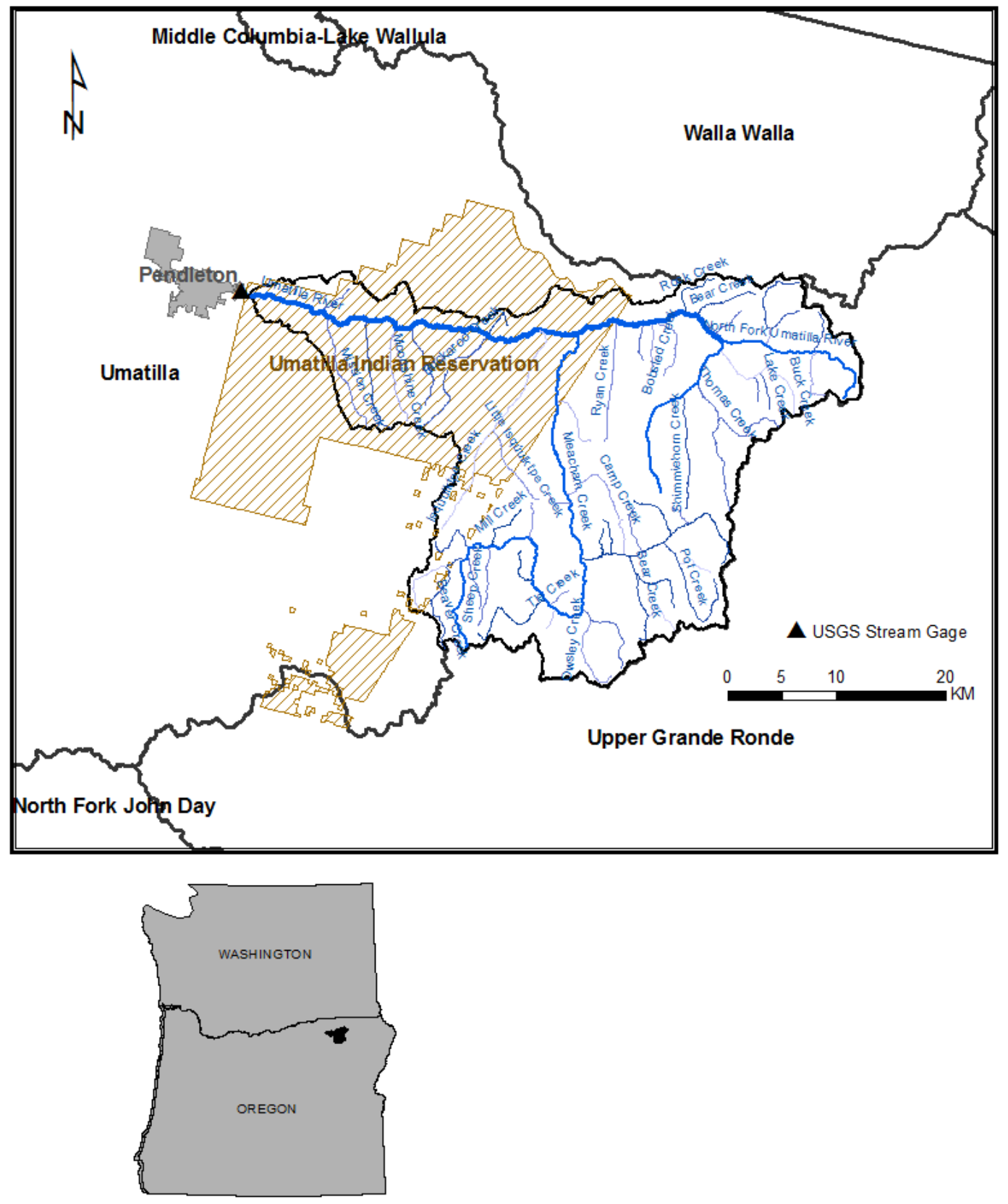

Figure 1: The study site is $2,365 \mathrm{~km} 2$ in the upper Umatilla River Basin in northeastern Oregon. 

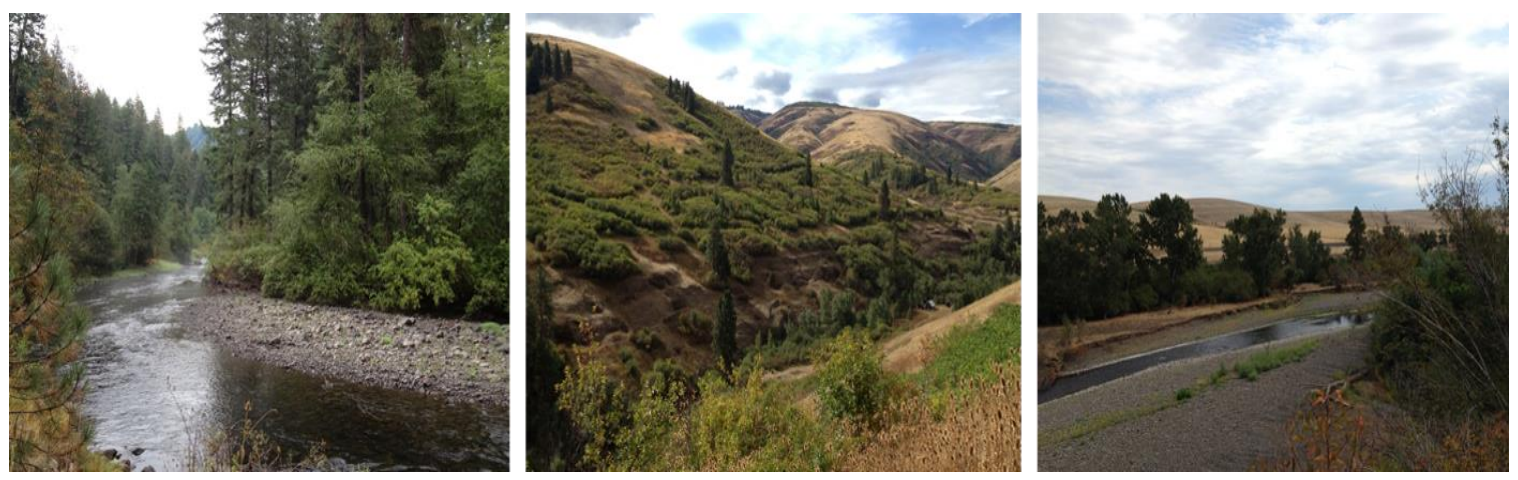

Figure 2: Photos of the URB upstream in the Blue Mountains (L), hilly grasslands at mid-elevation (M), and downstream near the City of Pendleton (R).

\subsubsection{Geology}

The geologic structure of the basin has an effect on groundwater flow and availability. The URB includes two geologic features, the Deschutes-Umatilla Plateau and the Blue Mountains. The study site is underlain by the Miocene CRBG that erupted 17-6 million years ago. It spans eastern Washington, northeastern Oregon and west central Idaho (Hooper, 1982; Tolan, 2009). From oldest to youngest in geologic age, the Grande Ronde basalt, Wanapum Basalt, and Saddle Mountain Basalt, are formations within the CRBG, each with unique physical, chemical, and paleomagnetic properties (Reidel et al, 1989b). The Grande Ronde Basalt and Wanapum Basalt formations are the primary CRBG formations on the UIR. The Grand Ronde Basalt is thicker and is found to have more permeable interflow zones and has a greater extent than other basalt formations (CTUIR, 2007; Burns et al, 2012). 


\subsubsection{Hydrogeology}

CRBG aquifers are an important regional aquifer system providing the primary water supply for the URB. They are generally classified to be semiconfined to confined, with water bearing units and transmitting zones occurring in the Grande Ronde, Wanapum, and Saddle Mountains basalt groups, the interstratified Ellensburg Formation, sedimentary interbeds, interflow zones and in basalt flow tops (Gephart et al, 1979; USDOE, 1988; Hansen et al, 1994; Packard et al, 1996; Sabol \& Downey, 1997; Bauer \& Hansen, 2000; Tolan, 2009). Reidel and Hooper (1989) provide a comprehensive summary on the Columbia River flood province. Characterization of the CRBG aquifer system (Drost \& Whiteman, 1986; Vaccaro,1999; Tolan, 2009), groundwater recharge estimates (Bauer \& Vaccaro, 1990), and groundwater behavior (Davies-Smith et al, 1988) offer a window into the complexity of the CRBGs not represented by PRMS, but when paired with the Modular Groundwater Flow Model (MODFLOW), surface and groundwater interactions can be quantified in a coupled Groundwater and Surface-Water Flow Model (GSFLOW) (Markstrom, 2008). 


\section{Data and Methods}

\subsubsection{Historic Climate Data}

Climate data consisting of precipitation, minimum and maximum temperature, and solar radiation are the primary inputs in a PRMS simulation (Leavesley et al., 1983; Markstrom et al., 2008; Fig. 4). For this study, daily timeseries of precipitation, minimum and maximum temperature were obtained for model input using the USGS' Geo Data Portal (GDP). Solar radiation data was not obtained, in which case PRMS internally estimates daily shortwave solar radiation (Markstrom et al., 2015). Discretized HRUs were uploaded to the GDP as a shapefile to obtain a daily time series of precipitation and minimum and maximum temperature (Table 1).

University of Idaho Gridded Surface Meteorological data (METDATA) for the continental U.S. were used for climate forcings at 4-km (1/24-degree) resolution for model calibration (1995-2010). High resolution gridded dataset was derived from observations and regional reanalysis using a hybrid method, combining spatially rich data from the Parameter-elevation Regressions on Independent Slopes Model (PRISM) and temporally rich data from the North America Land Data Assimilation System Phase 2 (NLDAS-2), (Mitchel et al., 2004; Daly et al., 2008; Abatzoglou, 2013).

\subsubsection{Future Climate Data}

Downscaled future climate data with a resolution of 4-km (1/24-degree) was obtained for the 1980s (1970-1999), 2020s (2010-2039), 2050s (2040- 
2069), and 2080s (2070-2099). Future climate data were derived using the Multivariate Adaptive Constructed Analogs statistical downscaling method (MACA), a non-interpolated-based approach (Abatzoglou \& Brown, 2012). Data from the Coupled Model Inter-Comparison Project 5 (CMIP5) use Representative Concentration Pathways (RCPs), instead of emission scenarios that define concentrations of greenhouse gases and aerosols. RCP4.5 and RCP8.5 scenarios were used in this analysis, where RCP4.5 is a medium stabilization scenario where an additional $4.5 \mathrm{~W} / \mathrm{m}^{2}$ of radiative forcing energy is trapped in the atmosphere by year 2100 (Van Vuuren et al., 2011). RCP8.5 has a very high baseline emission scenario at $90^{\text {th }}$ percentile, where an additional $8.5 \mathrm{~W} / \mathrm{m}^{2}$ is trapped by 2100 , where no climate action is executed (Van Vuuren et al., 2011).

Ten Global Climate Models (GCMs) were used in this study (Table 3), based on a model evaluation in the Pacific Northwest, that used eighteen performance metrics to rank model performance (Rupp et al., 2013). The GCMs chosen in this study had a low normalized error score compared to other models and were chosen based on availability (Rupp et al., 2013). These models take into account annual and decadal climate variability associated with the El Nino Southern Oscillation and the Pacific Decadal Oscillation.

Model performance for each GCM was compared to observations in the baseline period where temperature and precipitation predictions were analyzed for any discrepancies. There are minor differences in precipitation projections as differences are minimal $(<.02)$, with greater differences in temperature $\left(<2.64^{\circ} \mathrm{C}\right)$ 
but not large enough to exclude any GCMs (See Appendix C). Further, bias corrections were not made due to taking the ensemble mean of $10 \mathrm{GCMs}$, a consensus of climactic change, and because studies have found little to no difference in selecting or weighting GCM output (Mote et al., 2011).

Table 1: Datasets, models and tools used for analysis, including data derived.

\begin{tabular}{|c|c|c|}
\hline Data & $\begin{array}{l}\text { Resolu } \\
\text { tion }\end{array}$ & Source \\
\hline Historic Climate Data & $4-\mathrm{km}$ & Abatzaglou (2012) \\
\hline Future Climate Data & $4-\mathrm{km}$ & Abatzaglou (2012) \\
\hline $\begin{array}{l}\text { Streamflow - US Geological Survey Stream Gage } \\
14020850\end{array}$ & & USGS (2013) \\
\hline Soils - NRCS State Soils Geographic & $30-m$ & STATSGO (2013) \\
\hline Land Use \& Land Cover - Nat'I Land Cover Data & $30-\mathrm{m}$ & USGS (2013) \\
\hline DEM - National Elevation Dataset & $30-\mathrm{m}$ & USGS (2013) \\
\hline Point data and acres burned in the URB & & USFS, Umatilla Natl. Forest \\
\hline Models \& Tools & $\begin{array}{l}\text { Versio } \\
\text { n }\end{array}$ & \\
\hline Precipitation Runoff Modeling System (PRMS) & 3.0 .5 & USGS (2013) \\
\hline Geo Data Portal (GDP) & & USGS (2013) \\
\hline Let Us Calibrate (LUCA) & & USGS (2013) \\
\hline Web-based Hydrograph Analysis Tool & & Purdue University (2015) \\
\hline
\end{tabular}

\subsection{Methods}

\subsubsection{PRMS}

The Precipitation Runoff Modeling System, version 3.0.5, was used in this study. It is a distributed-parameter, physical-process based watershed model developed by the USGS (Leavesley et al., 1983; Marskstrom et al., 2008, 2015). PRMS workflow includes preparation of input files including historical data, and 
basin characteristics for each $\mathrm{HRU}$, followed by calibration and validation, then running future climate data under different land cover scenarios (Fig. 4). PRMS estimates water-balance relations, stream flow regimes, soil-water relations and groundwater recharge (Markstrom et al., 2008). It simulates hydrologic processes for evaluation of the distribution of water among runoff, evapotranspiration, and infiltration (Cherkauer, 2004; Markstrom et al., 2015). Precipitation, air temperature, and solar radiation are the primary inputs into PRMS to compute evaporation, transpiration, sublimation, snowmelt, surface runoff, and infiltration (Fig. 3). Water that surpasses field capacity is routed to the subsurface reservoir or groundwater reservoirs. From these two reservoirs, water becomes interflow or groundwater discharge to a stream or lake, if it does not enter the ground-water sink where recharge occurs (Fig. 3; Markstrom, 2008, 2015). However, in this study the ground-water sink option was not used. 


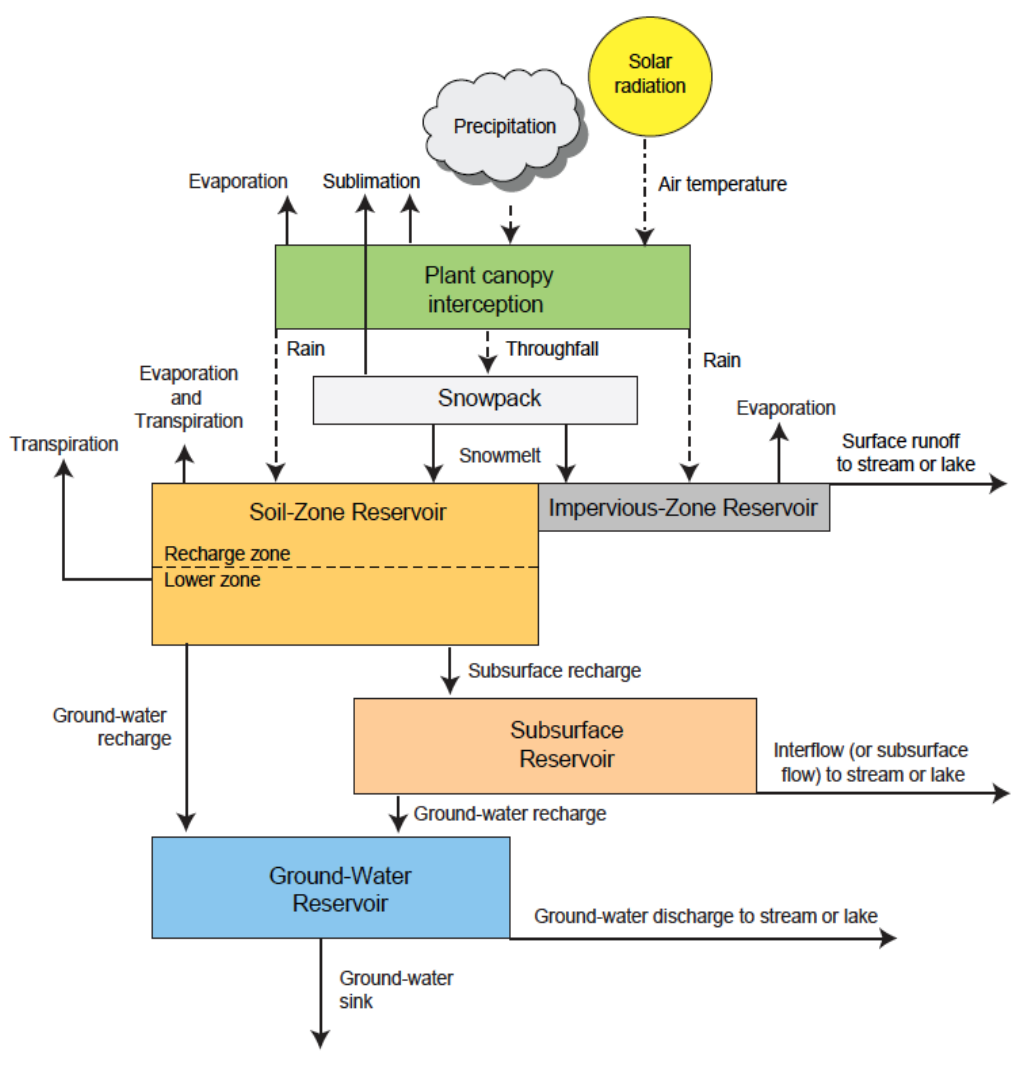

Figure 3: Schematic diagram of a watershed and its meteorological inputs simulated by PRMS (Markstrom et al., 2008) 


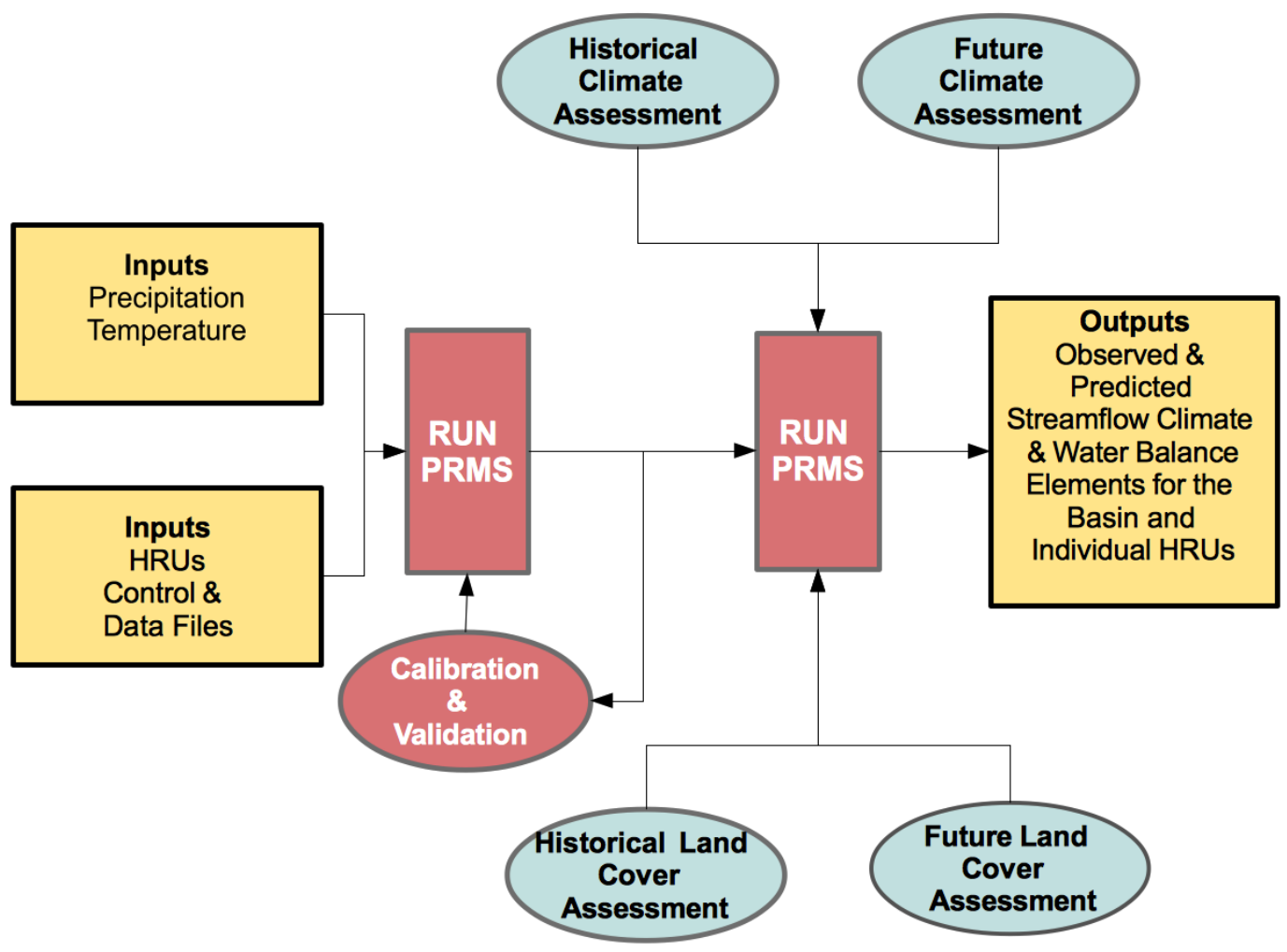

Figure 4: Workflow of data input, PRMS calibration, and data output.

3.3.2 Indicators for detecting climate change impact

Water and energy balance variables will be evaluated under two different climate scenarios with low and high radiative forcings, $\mathrm{RCP} 4.5$ and RCP8.5, and comparing these scenarios with historical conditions in a multi-model ensemble approach. The following climate change impact detection indices were used: (1) Change in temperature and percent change in precipitation. (2) Ensemble mean changes in annual and seasonal runoff. (3) Center timing of streamflow (CT), indicating what date half of the water for that water year has passed. (4) The ratio 
of snow water equivalent to precipitation (SWE/P). (5) Potential recharge, to analyze ground and surface water interactions. (6) The baseflow index (BFI), to indicate groundwater flow contributions to surface water flows. (7) Lastly, the Coefficient of Variation (COV) was calculated for seasonal flows to understand the variability and uncertainty in GCM projections within the winter and summer seasons. Four of the seven indices were used to analyze watershed response to land cover change, including CT, Seasonal flows, SWE/P, and basin recharge.

Climate change detection indices were compared between the means of historical and future time periods and deemed statistically significant at the $95 \%$ confidence interval. Parametric analysis was completed with one-way analysis of variance (ANOVA), and non-parametric testing was completed with the KruskalWallis test. After detecting an overall significant difference, multiple comparisons were analyzed with Tukey's honest significance test or Kruskal Wallis' multiple comparisons test.

\subsubsection{Generation of Hydrologic Response Units (HRU)}

The discretization of HRUs is based on hydrologic and physical characteristics such as land use, vegetation, soil type, elevation, drainage boundaries, geology, and more (Markstrom et al., 2015). Partitioning the watershed to generate HRUs in the Umatilla River Subbasin was completed using watershed boundaries, soils, and land cover to derive a total of $107 \mathrm{HRUs}$ (Table 2, Fig. 5). Each HRU unit is homogenous with unique physical and hydrologic facets, yielding a homogenous hydrologic response to climatic inputs. For each HRU, a daily water and energy balance is computed and the sum of the 
responses of all HRUs, weighted on a unit-area basis, calculates the daily system response of the basin (Leavesley et al., 1983, Markstrom et al., 2015).

The number and size of HRUs is left to the discretion of the modeler, although a higher number of HRUs may result in diminished returns as the study site is broken down into smaller units while the real system is unchanged, where the sum and average of water and energy balances for each HRU will have no significant change. Partitioning HRUs smaller than $4-5 \%$ was avoided for dailyflow computations as suggested by Leavesley et al. (1983).

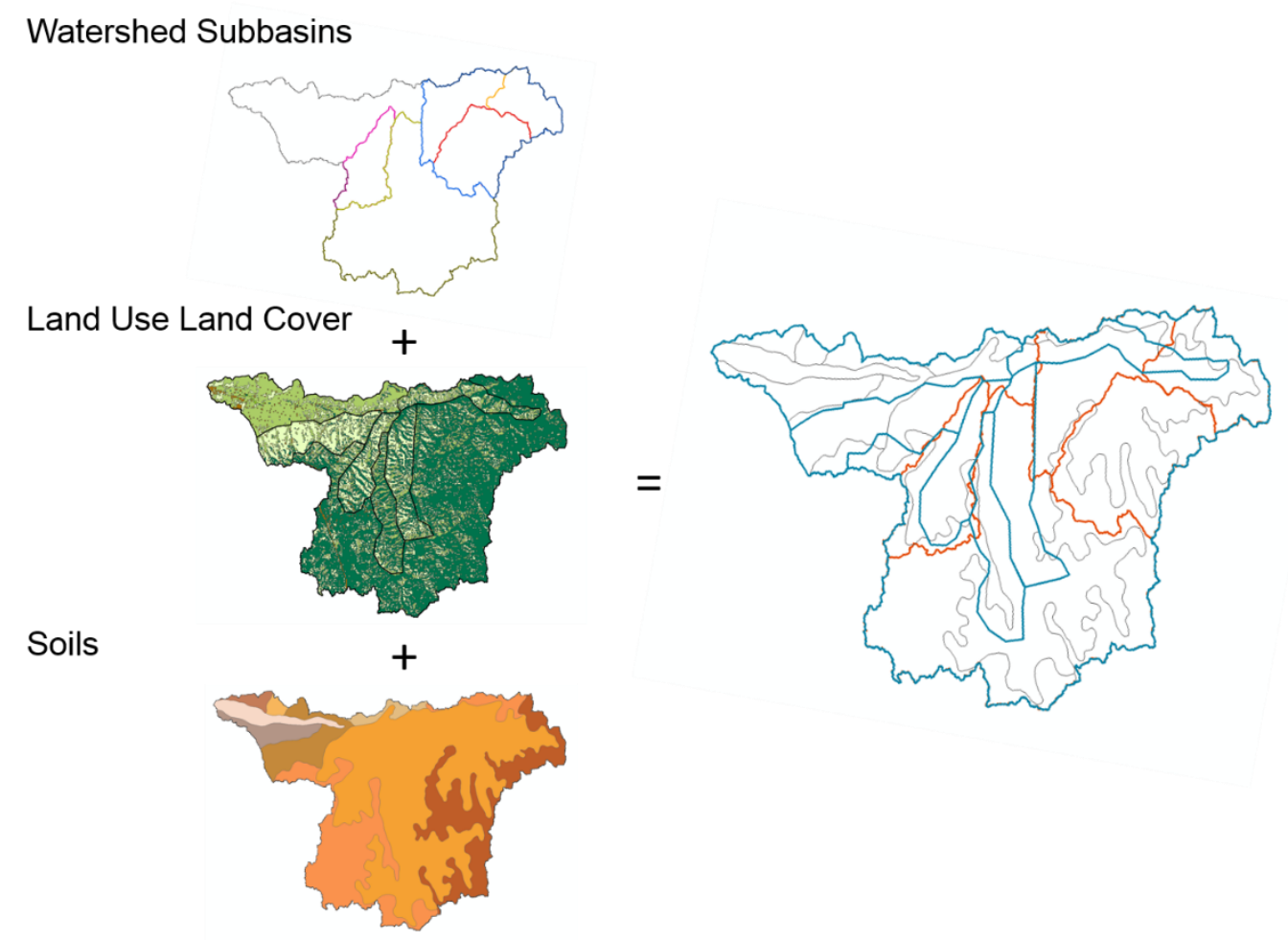

Figure 5: Discretization of $107 \mathrm{HRUs}$ included using watershed subbasins (T), land use land cover (M), and soil type (L). 


\subsubsection{Post Fire Analysis}

To analyze the watershed response to forest fire, variables associated with land cover change were modified. Assumptions were made that the following variables, when increased or decreased, would mimic post-fire conditions (Table 2). Similarly, forest-cover reduction was analyzed by Konrad (2004), where model parameters pertaining to seasonal vegetation cover, shortwave radiation transmitted through the canopy, upper soil storage capacity, and total soil storage capacity were modified. Shapefile data on fire history in the URB was obtained from the U.S. Forest Service at Umatilla National Forest. Areas of fire occurrence in the 1980s, was used as a baseline map from which it was increased three (188,994 ac.) and nine times (190,927 ac.) for the 2050 s, and 2080s, respectively. Turner et al. (2015) observed the average area burned per year increased three to nine fold in the Willamette River Basin, Oregon. Two models, HadGEM2 and MIROC5, were run under the 8.5 scenario with different parameters. An extremely warm model, HadGEM2, has acute summer drying and is generally warm year-round and was chosen to represent the RCP 8.5 scenario in the 2080 s with high radiative forcings, while MIROC5 is representative of an intermediate, warm model and was chosen to simulate runoff in the 2050s. These parameters were closely related to characteristics of a post-fire response, including loss of vegetation cover, increase in soil hydrophobicity (Soto \& Diaz-Fierros, 1998; Neary \& Ffolliott, 2005; Versini et al., 2013), reducing soil infiltration capacity and increasing runoff (Letey, 2001; Versini et al., 2013, Springer 2015). Other watershed-scale effects of fire are 
differential and depends on burn severity, intensity, extent and the regional

hydro-climatic regime (Gresswell, 1999; Sillins, 2014).

Table 2: Model parameters changed for forest cover reduction.

\begin{tabular}{lllll}
\hline PRMS Parameter & Description & $\begin{array}{l}\text { Initial } \\
\text { Value }\end{array}$ & $\begin{array}{l}\text { Assigned } \\
\text { Value }\end{array}$ & $\% \boldsymbol{\Delta}$ \\
\hline COVDEN_SUM & Summer vegetation cover density & 0.5 & 0.1 & $-80 \%$ \\
COVDEN_WIN & Winter vegetation cover density & 0.5 & 0.1 & $-80 \%$ \\
RAD_TRNCF & Solar radiation transmission coeff. & 0.3 & 0.5 & $40 \%$ \\
SOIL_RECHR_MAX & Max. storage for soil recharge zone & 1.64 & 0.55 & $-67 \%$ \\
SOIL_MOIST_MAX & Max. value of water for soil zone & $2.14-12.54$ & 1.08 & $-50 \%$ \\
\hline
\end{tabular}

Table 3: Global Climate Models used in this study.

\begin{tabular}{lll}
\hline Model Name & Model Agency & Country \\
\hline CNRM-CM5 & Natl. Centre of Meteorological Research & France \\
HadGEM2-ES & Met Office Hadley Center & UK \\
CanESM2 & Canadian Centre for Climate Modeling \& Analysis & Canada \\
MIROC5 & $\begin{array}{l}\text { Atmosphere \& Ocean Research Inst, Japan \& } \\
\text { Japan }\end{array}$ & \\
NorESM1-M & Natl. Inst. for Environmental Studies, Japan & Norwegian Climate Center \\
CSIRO- & Commonwealth Sci. \& Industrial Res. & Australia \\
Mk3.6.0 & Organizational/Queensland Climate Change & \\
& Centre of Excellence & Japan \\
MRI-CGCM3 & Meteorological Research Institute & Russia \\
INM-CM4 & Institute for Numerical Mathematics & China \\
BCC-CSM1.1 & Beijing Climate Ctr., China Meteorological Admin. \\
GFDL-ESM2M & NOAA Geophysical Fluid Dynamics Laboratory & USA \\
\hline
\end{tabular}

\subsection{Calibration \& Verification}

An important step in hydrologic model development is model calibration. There are two main approaches to estimate model parameters, an a priori approach using theoretical or empirical relationships in comparison to observed data that 
capture the physical characteristics of a watershed, and the second, automatic model calibration (Duan \& Gupta et al, 2003). The second approach was used to calibrate the PRMS model by adjusting parameter values to best match simulated runoff values to observed streamflow conditions. The hydrograph peak, volume, and time, were analyzed and compared between observed and simulated flow.

Model calibration was completed using LUCA, version 2.0.0, developed by the USGS and written in the JAVA programming language. LUCA is a multipleobjective, stepwise, automated procedure for model calibration with a graphical user interface, and uses the Shuffled Complex Evolution global search algorithm to calibrate PRMS and models developed with the USGS's Modular Modeling System (MMS) (Duan, 1991; Hay \& Umemoto, 2006). MMS is a framework for modeling and is an integrated system of computer software to combine userselected algorithms to simulate physical processes (Leavesley et al. 1996). Multiple objective calibration allows for multiple parameters such as saturation threshold, Potential Evapotransporation (PET) sublimation of snow surface to be calibrated with observed streamflow data (Hay \& Umemoto, 2006).

LUCA was run at four steps and six rounds using fifteen years of historic streamflow for calibration (1995-2010) and four years for verification (20102014). The first step calibrated the water balance, the second step, daily flow timing of all flows, the third step, daily flow timing of high flows, and the fourth 
step, daily flow timing of low flows (Table 4). Parameters were adjusted depending on whether the model was over- and under-predicting volume in low and high precipitation years. Final parameter values fall within range of probable parameter ranges (Table 4). The timing of runoff peaks were also analyzed in addition to comparing the monthly annual mean of observed and simulated streamflow (Fig. 6)

Table 4: Tabulated summary of final parameters used for calibration.

\begin{tabular}{|c|c|c|c|c|}
\hline Step & Calibration Data Set & Parameters & Final Value & Range \\
\hline \multirow[t]{2}{*}{1} & Water Balance & rain_cbh_adj_mo & 1.128 & $0.6-1.4$ \\
\hline & & snow_cbē adj_mo & 1.4 & $0.6-1.4$ \\
\hline \multirow[t]{11}{*}{2} & Daily Flow Timing (all flows) & adjmix_rain_hru_mo & $0.4-1.4$ & $0.6-1.4$ \\
\hline & & cecn_coef & 2.12 & $2.0-10.0$ \\
\hline & & emis_noppt & 0.975 & $0.76-1.0$ \\
\hline & & freeh2o_cap & 0.019 & $0.01-0.2$ \\
\hline & & K_coef & 23.859 & $1-24.0$ \\
\hline & & potet_sublim & 0.541 & $0.1-0.75$ \\
\hline & & slowcoef_lin & 0.004 & $0.001-0.5$ \\
\hline & & soil_moist_max & $2.14-12.537$ & $2-10$ \\
\hline & & soil_rechr_max & 1.643 & $1.5-5$ \\
\hline & & tmax_allrain_hru_mo & $22-52$ & $34-45$ \\
\hline & & tmax_allsnow_hru & 37 & $30-40$ \\
\hline \multirow[t]{4}{*}{3} & Daily Flow Timing (high flows) & fastcoef_lin & 0.005 & $0.001-0.8$ \\
\hline & & pref_flow_den & 0.1 & $0-0.1$ \\
\hline & & sat_threshold & $3.031-13.955$ & $1.0-15.0$ \\
\hline & & smidx_coef & 0.001 & $0.001-0.06$ \\
\hline \multirow[t]{3}{*}{4} & Daily Flow Timing (low flows) & gwflow_coef & 0.024 & $0.001-0.1$ \\
\hline & & soil2gw_max & 0.103 & $0-0.5$ \\
\hline & & ssr2gw_rate & 0.582 & $0.05-0.8$ \\
\hline \multirow[t]{6}{*}{1} & Daily Flow Timing (low flows) & gwflow_coef & 0.024 & $0.001-0.5$ \\
\hline & & gwsink_coef & 0.02 & $0.0-0.05$ \\
\hline & & soil2gw_max & 0.103 & $0-0.5$ \\
\hline & & ssr2gw_rate & 0.582 & $0.05-0.8$ \\
\hline & & soil_moist_max & $2.14-12.537$ & $2-10$ \\
\hline & & slowcoef_sq & 0.161 & $0.05-0.3$ \\
\hline
\end{tabular}


LUCA uses streamflow data obtained for a selected basin to calibrate simulated runoff. PRMS requires using unregulated streamflow to calibrate the model parameters in order to determine hydrologic conditions that are representative of the watershed. USGS Stream Gage 14020850, Umatilla River West Reservation Boundary Near Pendleton, OR, was used (Fig. 1). Although the stream gage is regulated and diverted for municipal uses near the City of Pendelton, it was determined through communication with the Department of Natural Resources, CTUIR, that consumptive use is miniscule to the total volume of streamflow and was determined negligible. Otherwise, consumptive use would be calculated and added to the hydrograph to obtain normal streamflow conditions. Consumptive use includes irrigation, municipal, and all other uses, such as domestic needs (Cooper, 2002).

\subsubsection{Model Performance Evaluation}

To analyze PRMS model performance, four statistical analyses were used: Nash-Sutcliffe efficiency (NSE), percent bias (PBIAS), Kling-Gupta efficiency (KGE), and the Normalized Root Mean Square Error (NRMSE) (Table 5). The Nash-Sutcliffe coefficient $R^{2}$ indicates accuracy with a range of negative infinity to one, where one is a perfect fit. A negative coefficient would indicate the mean value of observed data would be a better predictor than the model, and a value of zero would indicate the model would not yield better results than using the average of the flows (Nash and Sutcliffe, 1970; Bathurst, 1997; Krause et. al, 2005). 


$$
N S E=\frac{\sum_{i=1}^{n}\left(y_{i}^{\rho b s}-y_{i}^{o b s}\right)^{2}}{\sum_{i=1}^{n}\left(y_{i}^{o b s}-y^{\text {mean }}\right)^{2}}
$$

The PBIAS determines under or over-prediction of simulated data in comparison to observed data with an optimal value of 0 indicating optimal simulation. A negative value indicates underestimation, while a positive value indicates overestimation of model performance (Moriasi, 2007).

$$
\text { PBIAS }=\frac{\sum_{i=1}^{n}\left(y_{i}^{s i m}-y_{i}^{\rho b s}\right) 100}{\sum_{i=1}^{n}\left(y_{i}^{\rho b s}\right)}
$$

KGE is an alternative to NSE used here, where the closer KGE is to 1 on a scale from negative infinity to one, the more accurate the model is. Different components of the model area are evaluated, such as correlation, bias, and variability (Gupta et al. 2009).

$$
K G E=1-\sqrt{(r-1)^{2}+(\alpha-1)^{2}+(\beta-1)^{2}}
$$

NRMSE was also calculated where the lower the value, the lower the variance. RMSE is first calculated to indicate the differences, knows as residuals between 
simulated and observed values. The lower the percentage, the better the accuracy (Hyndman \& Koehler, 2006).

$$
\begin{gathered}
\text { NRMSE }=\frac{R M S E}{X_{\text {obs, } \max }-X_{\text {obs, } \min }} \\
R M S E=\sqrt{\frac{\sum_{i=1}^{n}\left(X_{\text {obs }, i}-X_{\text {mode }, i}\right)^{2}}{n}}
\end{gathered}
$$

Table 5: Tabulated summary of statistics used for calibration and validation.

\begin{tabular}{lllll}
\hline & NSE & \% Bias & KGE & NRMSE \\
\hline Initial Model Results & 0.04 & 4 & 0.57 & 97.7 \\
After Calibration (1995-2010) & 0.73 & 3.5 & 0.81 & 52.2 \\
Validation (2010-2014) & 0.73 & 3.5 & 0.83 & 52.1 \\
\hline
\end{tabular}

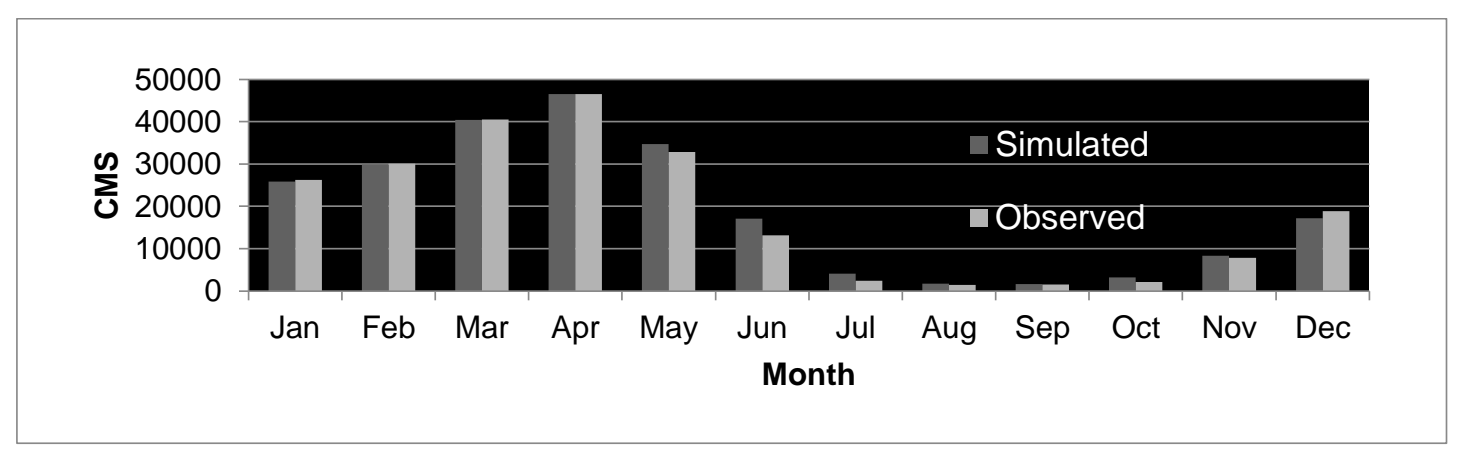

Figure 6: Historical and simulated mean monthly streamflow (1995-2010). 


\section{Results}

\subsubsection{Mean Annual Temperature}

Model uncertainty is observed when analyzing mean annual temperature for all GCMs for RCP 4.5 (Fig. 7). The range in annual average temperature increases from $8.6^{\circ} \mathrm{C}$ in the $2020 \mathrm{~s}$ to $9.5^{\circ} \mathrm{C}$ in the $2050 \mathrm{~s}$, to $10.2^{\circ} \mathrm{C}$ in the $2080 \mathrm{~s}$ in RCP 4.5. In RCP 8.5, the average annual temperature increases from $8.8^{\circ} \mathrm{C}$ in the 2020 s, to $10.2^{\circ} \mathrm{C}$ in the 2050 s to $12.1^{\circ} \mathrm{C}$ in the 2080 s (Fig. 8). By the end of the $21^{\text {st }}$ century, there is a $3.3^{\circ} \mathrm{C}$ increase in mean temperature in RCP8.5, and an increase in $1.6^{\circ} \mathrm{C}$ in the RCP 4.5 scenario.

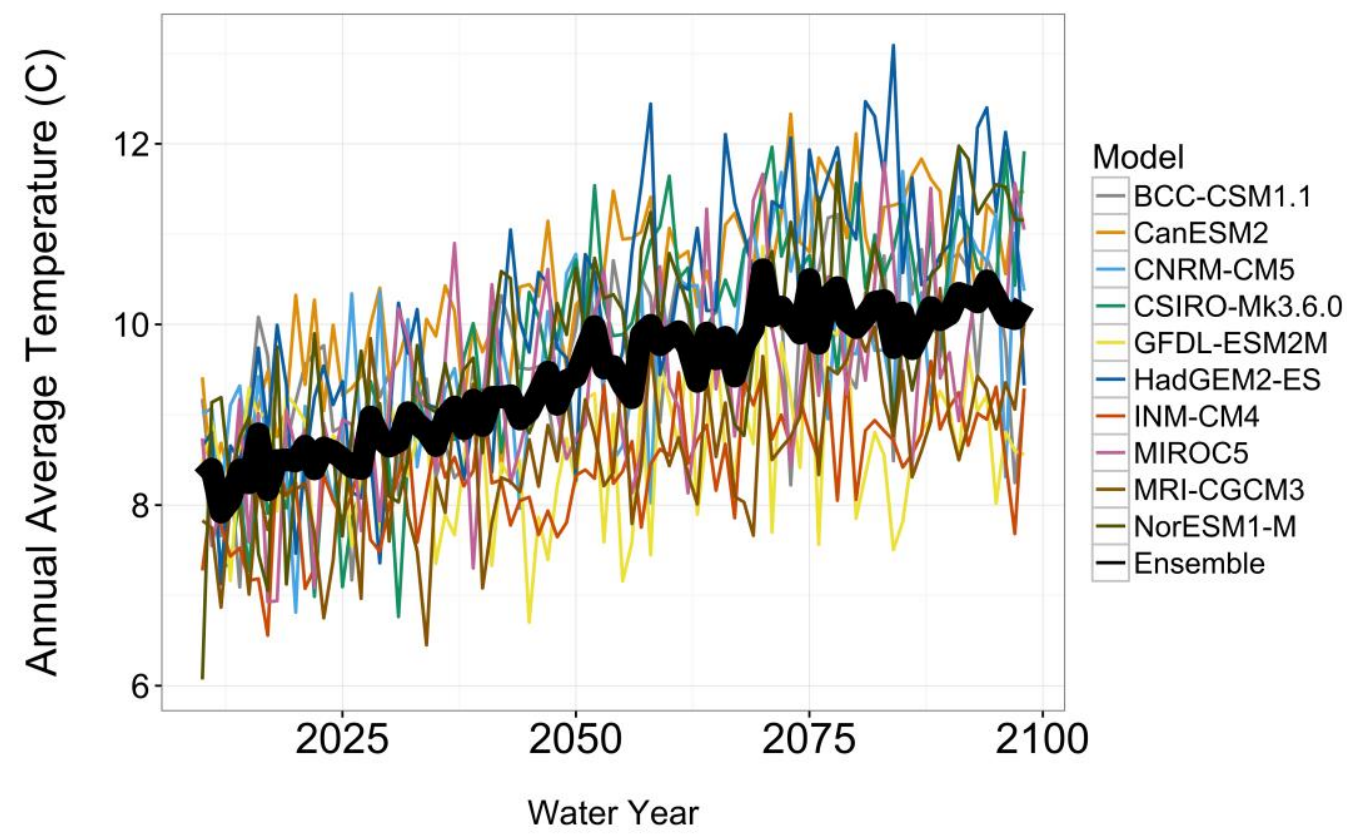

Figure 7: Annual mean temperature for all GCMs for RCP 4.5 with the ensemble mean in black. 


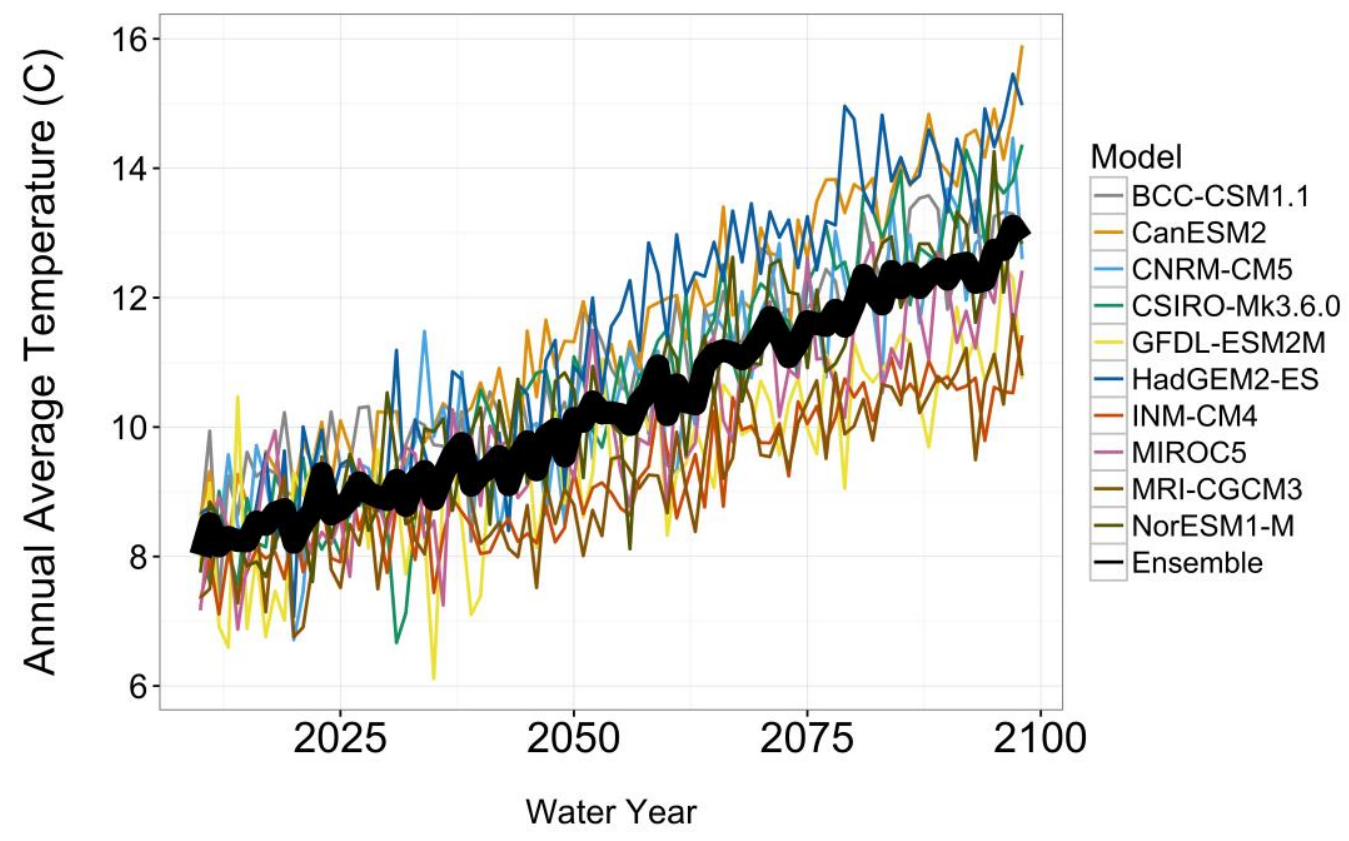

Figure 8: Annual mean temperature for all GCMs for RCP 8.5 with ensemble mean in black.

\subsubsection{Change in Temperature and Percent Change in Precipitation}

Air temperature is projected to steadily increase in the future with increased model variability toward the end of the $21^{\text {st }}$ century (Fig. 9). In the 2020s, there is less variation in change in temperature for both scenarios (Fig. 9). In RCP 4.5 in the 2020s, a change in temperature ranging from $0.7^{\circ} \mathrm{C}$ to $2.2^{\circ} \mathrm{C}$ is observed, and $0.9^{\circ} \mathrm{C}$ to $2.2^{\circ} \mathrm{C}$ in the RCP 8.5 scenario (Table 6). A percent change in precipitation from $-3.4 \%$ to $4.5 \%$ for RCP 4.5 and $-5.7 \%$ to $6.3 \%$ for RCP 8.5 is observed in the 2020 s (Table 6). In the 2050 s, change in temperature ranges from $1.2^{\circ} \mathrm{C}$ to $3.2^{\circ} \mathrm{C}$ for $\mathrm{RCP} 4.5$, and from $1.7^{\circ} \mathrm{C}$ to $4.1^{\circ} \mathrm{C}$ for $\mathrm{RCP}$ 8.5. This includes a range in percent change in precipitation from $-2.9 \%$ to $7.3 \%$ for 
RCP 4.5 and $-5.3 \%$ to $12.3 \%$ for RCP 8.5 (Table 6 ). In the 2080 s, change in temperature ranges from $1.6^{\circ} \mathrm{C}$ to $4.1^{\circ} \mathrm{C}$ in $\mathrm{RCP} 4.5$, and $3.1^{\circ} \mathrm{C}$ to $6.6^{\circ} \mathrm{C}$ in $\mathrm{RCP}$ 8.5, where percent change in precipitation ranges from $-4.8 \%$ to $13.6 \%$ in $\mathrm{RCP}$ 4.5 and $-3.6 \%$ to $11.3 \%$ in RCP 8.5 (Table 6 ). With each successive time period, there is a steady increase in the range of change in precipitation and temperature for all GCMs with the exception of a slight drop in percent change in precipitation in the 2080s in RCP 8.5 (Fig. 9).

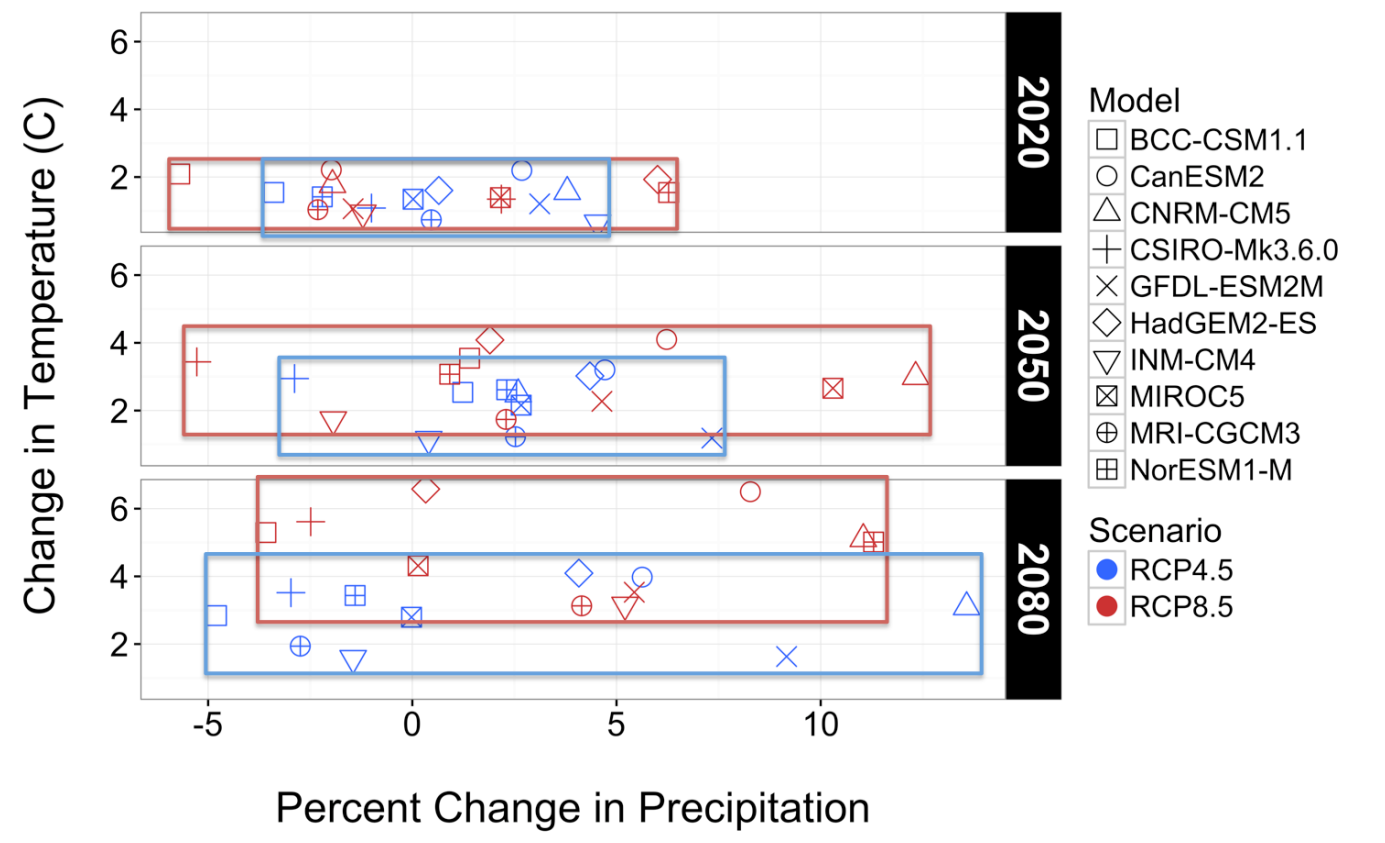

Figure 9: Change in temperature and annual percent change in precipitation in comparison to historical conditions for all GCMs. 
Table 6: Change in temperature $(T)$ and percent change in precipitation $(P)$

\begin{tabular}{clll}
\hline RCP 4.5 & & $\% \Delta$ in T & $\% \Delta$ in P \\
\hline 2020s & $\min$ & 0.65 & -3.40 \\
& $\max$ & 2.20 & 4.54 \\
2050s & $\min$ & 1.16 & -2.88 \\
& $\max$ & 3.20 & 7.34 \\
2080s & $\min$ & 1.58 & -4.79 \\
& $\max$ & 4.09 & 13.57 \\
\hline RCP 8.5 & & & \\
2020s & $\min$ & 0.94 & -5.69 \\
& $\max$ & 2.21 & 6.28 \\
2050s & $\min$ & 1.73 & -5.28 \\
& $\max$ & 4.10 & 12.32 \\
2080s & $\min$ & 3.13 & -3.58 \\
& $\max$ & 6.58 & 11.30 \\
\hline
\end{tabular}

\subsubsection{Seasonal Change in Temperature and Percent Change in Precipitation}

Seasonal change in temperature is apparent in both winter and summer, in comparison to the historical period (Fig. 10). There is less model uncertainty in the winter with more variation in the summer season throughout the century in both scenarios for both temperature and precipitation. In the summer, there is substantial variability in model predictions in change in temperature in the 2050s and 2080s. Percent change in precipitation increases slightly and consistently with less GCM uncertainty in the winter in comparison to summer for both scenarios in the 2020s, 2050s, and 2080s (Table 7). In the summer, there is a significant increase in percent change in precipitation with high model uncertainty in both scenarios particularly in the 2050s and 2080s (Table 7). 


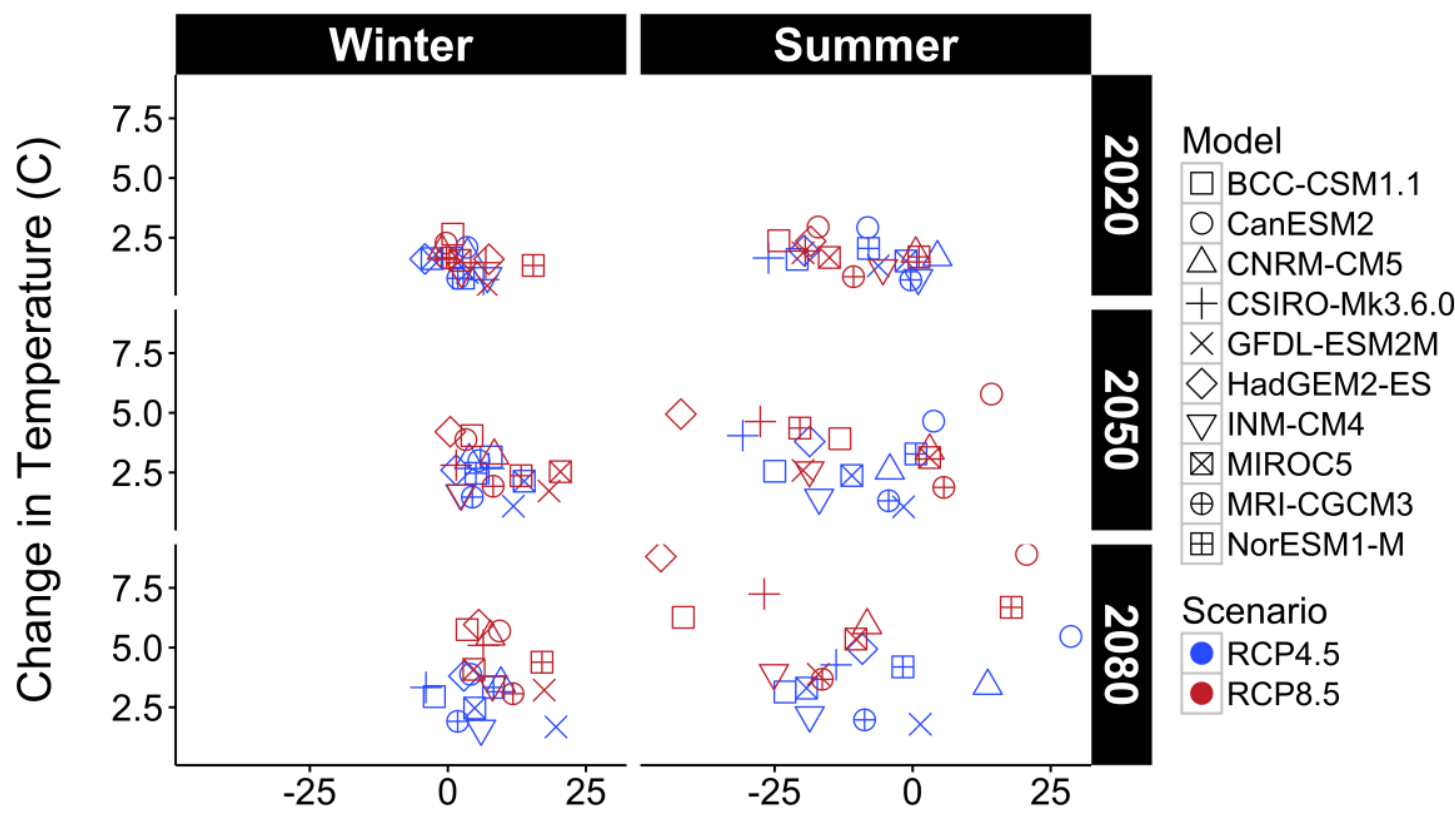

Percent Change in Precipitation

Figure 10: Change in seasonal temperature $(T)$ and percent change in precipitation $(\mathrm{P})$ for all GCMs in comparison to historical records.

Table 7: Minimum and maximum values of change in seasonal temperature (T) and percent change in precipitation $(\mathrm{P})$ in comparison to historical records.

\begin{tabular}{clllll} 
& & \multicolumn{3}{c}{ Winter } & \multicolumn{3}{c}{ Summer } \\
RCP 4.5 & & $\% \Delta$ in T & $\% \Delta$ in $\mathbf{P}$ & $\% \Delta$ in T & $\% \Delta \mathbf{P}$ \\
\hline 2020s & $\min$ & 0.8 & -4.1 & -4.1 & -26.1 \\
& $\max$ & 2.1 & 7.1 & 7.1 & 4.5 \\
2050s & $\min$ & 1.1 & 1.5 & 1.5 & -30.8 \\
& $\max$ & 3.2 & 13.8 & 13.8 & 3.8 \\
2080s & $\min$ & 1.6 & -4.0 & -4.0 & -23.1 \\
& $\max$ & 3.9 & 19.6 & 19.6 & 28.6 \\
\hline RCP 8.5 & & $\% \Delta$ in T & $\% \Delta$ in P & $\% \Delta$ in T & $\% \Delta \mathbf{P}$ \\
2020s & $\min$ & 0.5 & -1.1 & 0.9 & -24.2 \\
& $\max$ & 2.7 & 15.5 & 3.0 & 1.1 \\
2050s & $\min$ & 1.6 & 0.4 & 1.9 & -42.0 \\
& $\max$ & 4.2 & 20.4 & 5.8 & 14.3 \\
2080s & $\min$ & 3.1 & 3.5 & 3.7 & -45.6 \\
& $\max$ & 6.0 & 17.5 & 8.9 & 20.6 \\
\hline
\end{tabular}


Comparing individual GCM performance to observed historical data from 1980-1999 offered insight into the variability of GCM performance. The difference between observed and expected mean annual temperature is substantial (2.63$\left.1.46^{\circ} \mathrm{C}\right)$, with a median of $2.32^{\circ} \mathrm{C}(\mu=2.30 ; \sigma=0.40)$. The difference in mean annual precipitation between observed and expected was low $(0.008-0.016 \mathrm{~cm})$, with a median of $0.012 \mathrm{~cm}(\mu=0.012 ; \sigma=0.003)$, indicating that $\mathrm{GCM}$ simulations of precipitation are similar to observed precipitation.

\subsubsection{Center Timing of runoff}

CT was observed to occur earlier in the year with each time period in both the RCP 4.5 and RCP 4.5 scenarios (Fig. 11). In the 2020s in RCP 4.5, CT occurs 16 days earlier than the reference period (Table 8 ). In the 2050 s, it occurs 22 days earlier and 26 days earlier in the 2080 s, than the reference period in the 1980s (Table 8). For RCP 8.5 in the 2020s, CT occurs 16 days earlier than the reference period, and 24 days earlier in the 2050s, and occurs 33 days earlier in the 2080s (Table 8). Between the two scenarios, CT occurred earlier in the year by 7 days in the RCP 8.5 scenario at the end of the century (Table 8 ). Mean CT is not significantly different between the historical and future time periods in the RCP 4.5 scenario ( $p$-value $=0.25, \alpha=0.05)$ and $R C P 8.5$ scenario $(p$-value $=0.98)$ (See Appendix A). 


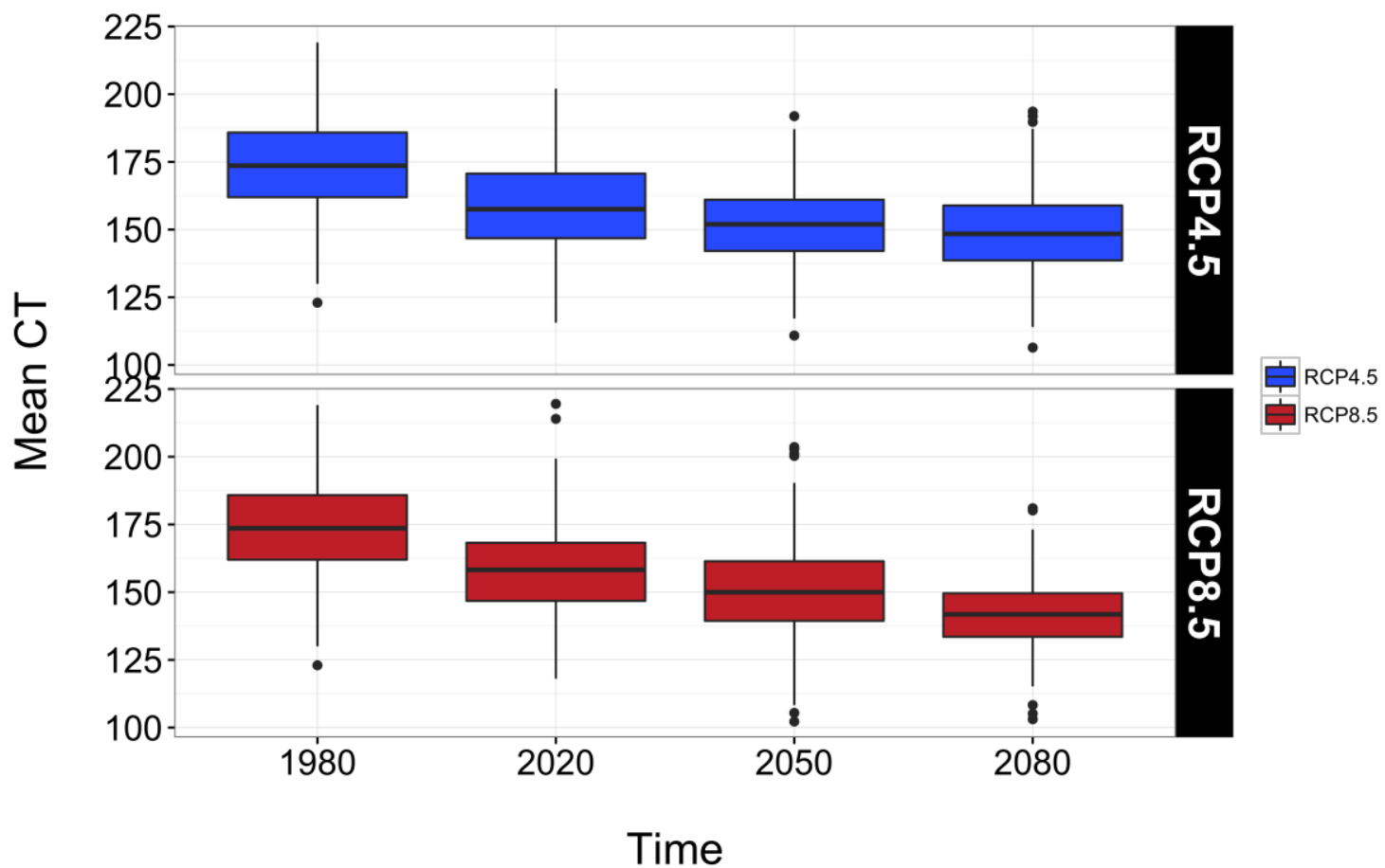

Figure 11: Ensemble mean basin CT for RCP 4.5 and RCP 8.5 scenarios.

Table 8: Mean CT before forest cover reduction.

\begin{tabular}{lll|ll}
\hline & \multicolumn{2}{c|}{ RCP 4.5 } & \multicolumn{2}{c}{ RCP 8.5 } \\
\cline { 2 - 5 } & $\boldsymbol{\mu}$ CT & \multicolumn{1}{c}{ Date } & $\boldsymbol{\mu ~ C T}$ & \multicolumn{1}{c}{ Date } \\
\hline 1980s & 174 & $6 / 23$ & 174 & $6 / 23$ \\
2020s & 158 & $6 / 7(16 d)$ & 158 & $6 / 7(16 d)$ \\
2050s & 152 & $6 / 1(22 d)$ & 150 & $5 / 30(24 d)$ \\
2080s & 148 & $5 / 25(26 d)$ & 141 & $5 / 21(33 d)$ \\
\hline
\end{tabular}

\subsubsection{Seasonal Flows}

Precipitation can be held in the snowpack depending on winter temperature, a key factor of streamflow timing and snow melt processes (Hamlet, 2007; Mote et al, 2005, Tohver et al, 2014). Analysis of seasonal flows provides insight into future streamflow behavior. In the URB, winter flows increased from 
historic to future conditions by $41 \%$ in the 2020 s, $64 \%$ in the 2050 s, and $71 \%$ in the 2080s in RCP 4.5 (Table 9, Fig. 12). In RCP 8.5, winter flow increased by $41 \%$ in the 2020 s, $73 \%$ in the 2050 s, and $99 \%$ in the 2080 s. Winter flows ranged from $24.98 \mathrm{~m}^{3} / \mathrm{s}$ to $30.33 \mathrm{~m}^{3} / \mathrm{s}$ in RCP 4.5 , and from $24.98 \mathrm{~m}^{3} / \mathrm{s}$ to $35.36 \mathrm{~m}^{3} / \mathrm{s}$ in RCP 8.5, compared to $17.69 \mathrm{~m}^{3} / \mathrm{s}$ in historic conditions (Table 9). Winter flows are significantly different between historical and future time periods in both scenarios, except between the 2050s and 2080s in the RCP 4.5 scenario (See Appendix A). There is less variability and a decrease in runoff in the summer (Fig. 12). Summer flow decreased by $39 \%$ in the 2020 s, $49 \%$ in the 2050 s, and $53 \%$ in the 2080s, in RCP 4.5 (Table 9). In RCP 8.5, summer flow decreased by $38 \%$ in the 2020 s, $51 \%$ in the 2050 s, and $66 \%$ in the 2080 s (Table 9). Mean runoff in the summer decreased $3.64 \mathrm{~cm}$ by the end of the century in RCP 4.5. (Table 9). In RCP 8.5, flow decreased $4.55 \mathrm{~cm}$ by the 2080s in comparison to the historical period in the 2080s (Table 9). Summer flows are significantly different in the RCP 4.5 scenario, except between the 2050s and 2080s, and between the 2020s and 2050s in the RCP 8.5 scenario (See Appendix A). 


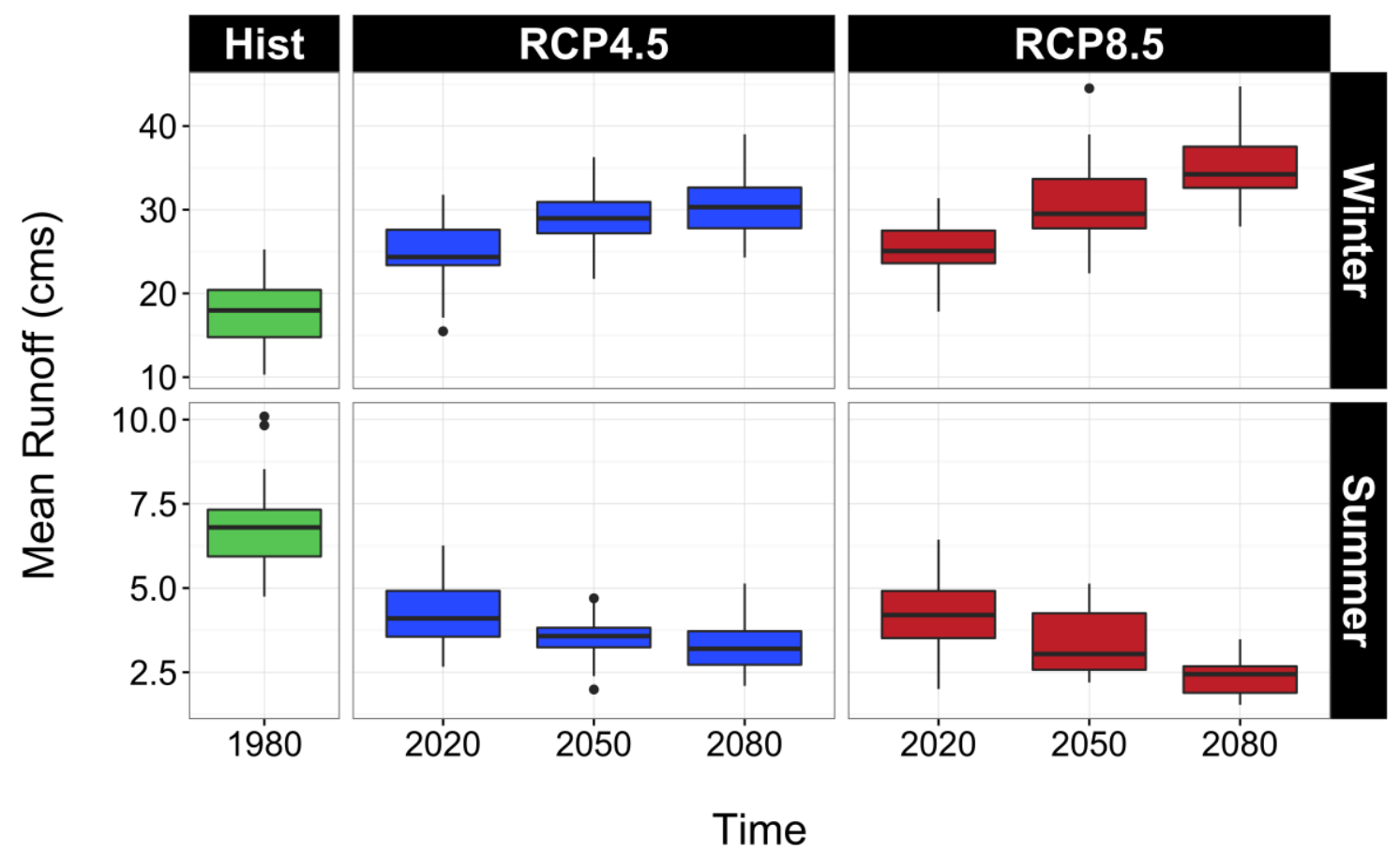

Figure 12: Change in basin mean runoff for summer and winter flow

Table 9: Percent change of seasonal flows in comparison to historical conditions.

\begin{tabular}{|c|c|c|c|c|c|c|c|c|c|}
\hline & & \multicolumn{4}{|c|}{ Winter $\left(\mathrm{m}^{3} / \mathrm{s}\right)$} & \multicolumn{4}{|c|}{ Summer $\left(\mathrm{m}^{3} / \mathrm{s}\right)$} \\
\hline & & 1980s & 2020s & 2050s & 2080s & 1980s & 2020s & 2050s & 2080s \\
\hline Historical & $\mu$ Runoff & 17.69 & & & & 6.916 & & & \\
\hline & Min & 10.3 & & & & 4.746 & & & \\
\hline & Max & 25.26 & & & & 10.092 & & & \\
\hline RCP 4.5 & $\mu$ Runoff & & 24.98 & 29.26 & 30.33 & & 4.25 & 3.52 & 3.28 \\
\hline & Min & & 15.48 & 21.74 & 24.3 & & 2.67 & 1.99 & 2.10 \\
\hline & Max & & 31.79 & 36.28 & 39.02 & & 6.26 & 4.70 & 5.14 \\
\hline & $\% \Delta$ & & 41.21 & 63.76 & 71.45 & & -38.56 & -49.13 & -52.65 \\
\hline RCP 8.5 & $\mu$ Runoff & & 24.98 & 30.63 & 35.36 & & 4.27 & 3.36 & 2.37 \\
\hline & Min & & 15.48 & 22.4 & 27.99 & & 2.01 & 2.20 & 1.54 \\
\hline & Max & & 31.79 & 44.5 & 44.74 & & 6.44 & 5.13 & 3.48 \\
\hline & $\% \Delta$ & & 41.21 & 73.15 & 98.89 & & -38.30 & -51.42 & -65.73 \\
\hline
\end{tabular}




\subsubsection{Snow Water Equivalent/Precipitation}

Winter temperature is a predictor of the timing of spring snowmelt and streamflow in snow dominated and rain-snow transient river basins in the PNW (Hamlet et al., 2007; Mote et al., 2005; Tohver et al., 2014). An important component of the snowpack is snow water equivalent (SWE), the amount of water that will infiltrate with potential for groundwater recharge that may sustain summer flows. The ratio of SWE over P decreases with each time period in the $21^{\text {st }}$ century for both RCP 4.5 and RCP 8.5 scenarios (Fig. 13). In RCP 4.5, SWE/P is observed to decrease $50 \%$ in the 2020 s in comparison to baseline conditions, $-75 \%$ in the 2050 s, and $-75 \%$ in the 2080 s (Table 10). In RCP 8.5 , there is a $50 \%$ decrease, $-75 \%$ in the 2050 s, and $-96 \%$ in the 2080 s (Table 10 ). April $1^{\text {st }}$ SWE decreases with each time period while mean precipitation is steady with slight increases with each time period (Table 10). Precipitation may increase but retention in the snowpack decreases throughout the century indicative of a hydrologic regime shift. All time periods are significantly different from each other at the 0.05 level of significance in the RCP 4.5 (p-value=2.2E-16) and RCP 8.5 $(p-$ value $=2.2 E-16)$ scenarios (See Appendix A). 


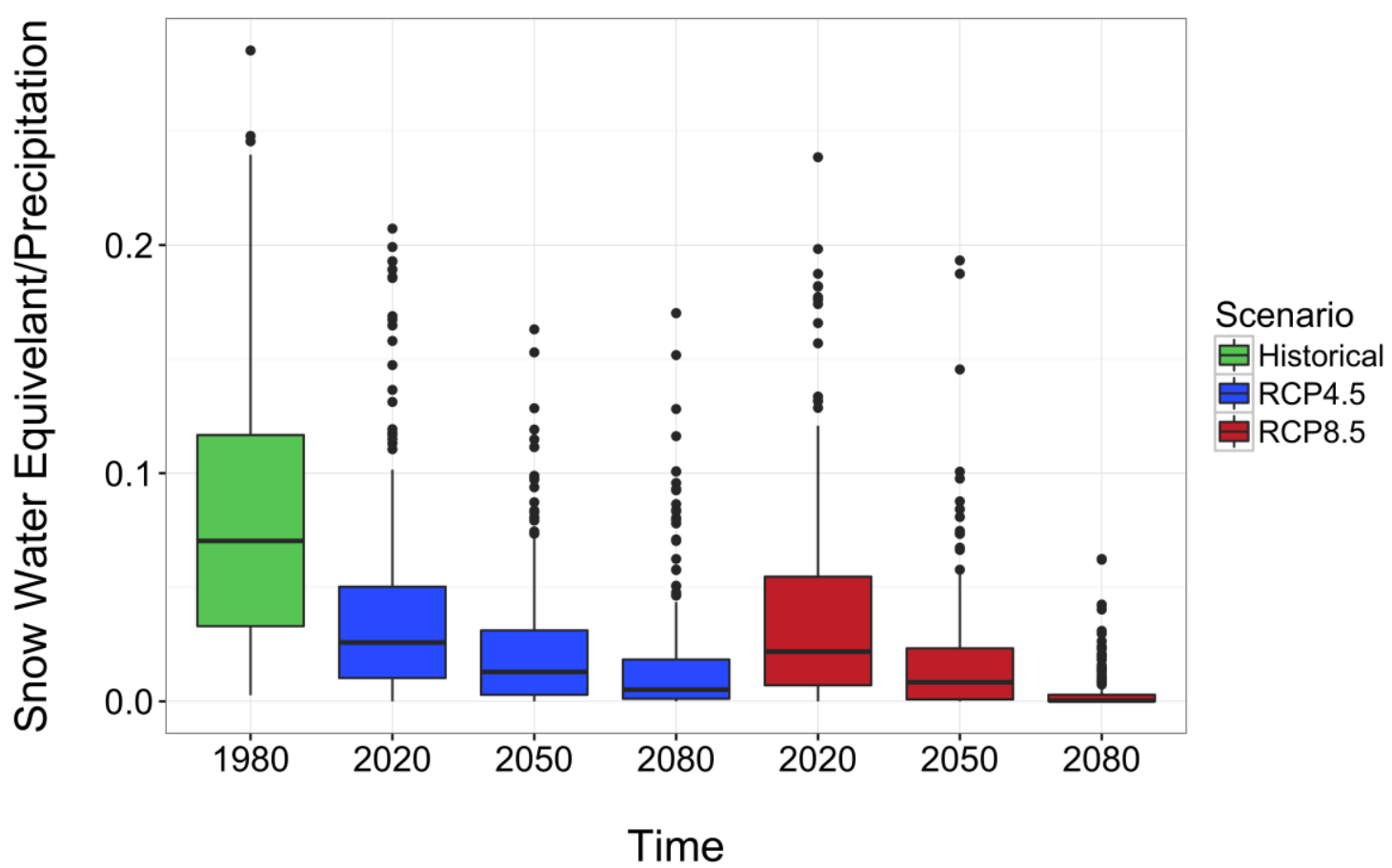

Figure 13: Ensemble mean of the ratio of snow water equivalent to precipitation.

Table 10: Percent change of SWE/P before forest cover reduction.

\begin{tabular}{cc|ccc|ccc}
\hline & Hist. & \multicolumn{3}{c|}{ RCP4.5 } & \multicolumn{3}{c}{ RCP8.5 } \\
\hline & 1980s & 2020s & 2050s & 2080s & 2020s & 2050s & $2080 \mathrm{~s}$ \\
\hline April 1 ${ }^{\text {st }} \mu$ & & & & & & & \\
SWE $(\mathrm{cm})$ & 6.6 & 3.2 & 2.0 & 1.4 & 3.2 & 1.4 & 0.0 \\
$\mu$ P (cm) & 75.7 & 77.4 & 79.2 & 78.2 & 76.7 & 79.5 & 80.9 \\
\hline$\mu$ SWE/P & 0.08 & 0.04 & 0.02 & 0.02 & 0.04 & 0.02 & 0.0036 \\
Min & 0.00 & 0.00 & 0.00 & 0.00 & 0.00 & 0.00 & 0.00 \\
Max & 0.29 & 0.21 & 0.16 & 0.17 & 0.24 & 0.19 & 0.062 \\
$\% \Delta$ & & -50.0 & -75.0 & -75.0 & -50.0 & -75.0 & -96.0 \\
\hline
\end{tabular}

\subsubsection{Potential Basin Recharge}

Quantifying groundwater is difficult, due to the spatial and temporal variability of water below the subsurface. The estimation of aquifer recharge and groundwater availability is critical to water management to meet domestic, 
municipal and ecological needs. In the URB, there is a consistent decrease in cumulative potential mean annual recharge in both future scenarios in comparison to historic conditions (Fig. 14). Potential basin recharge decreases $4.3 \%$ in the 2020 s, $-4.8 \%$ in the 2050 s and $-10.3 \%$ in the 2080 s, in comparison to the 1980s in RCP 4.5 (Table 11). Mean basin recharge is significantly different only between the 2080s and the 1980s, 2020s, and 2050s in RCP 4.5 (See Appendix A). In RCP 8.5, there is a $4.3 \%$ decrease in the $2020 \mathrm{~s},-7.4 \%$ in the 2050 s, and a $14.8 \%$ decrease in the 2080 s (Table 11). At the end of the $21^{\text {st }}$ century, mean recharge value decreases $4.4 \mathrm{~cm}$ in comparison to the $1980 \mathrm{~s}$ in RCP 4.5 and decreases $6.3 \mathrm{~cm}$ in RCP 8.5 (Table 11). Similar to RCP 4.5, in RCP 8.5 there is a significant difference between the 2080 s and the $1980 \mathrm{~s}$, 2020s, and 2050s, in addition to a significant difference between the 1980s and 2050s (See Appendix A).

There is a marked shift in peak recharge in both RCP 4.5 and RCP 8.5 scenarios, where peak recharge occurs in March for historical conditions and the 2020s, and shifts to January for both the 2050s and 2080s in RCP 4.5 (Fig. 15). Peak mean recharge by the end of the $21^{\text {st }}$ century decreases by $12.4 \%$ but with minimal change from $9.98 \mathrm{~cm}$ in the $1980 \mathrm{~s}$ to $8.74 \mathrm{~cm}$ in the $2080 \mathrm{~s}$ in RCP 4.5 (Table 12). In RCP 8.5, peak mean recharge occurs in March in the 2020s, and shifts to February in the 2050 s and to January in the 2080s (Fig. 16). Mean recharge decreases $6.6 \%$ in the 2020 s and decreases $10.8 \%$ in the 2050 s, but increases to historical levels with a $-0.3 \%$ change in the 2080 s (Table 12). Peak mean recharge is $9.98 \mathrm{~cm}$ in the baseline period and $9.95 \mathrm{~cm}$ at the end of the 
century, a $0.03 \mathrm{~cm}$ difference (Table 12). An increase in the 2080s in RCP 8.5 may be due to decreased canopy interception and less evaporation occurring at the watershed surface with an increased potential for infiltration to occur, contributing to basin recharge. This shift in basin recharge to earlier months is similar to a shift in center timing of flow, occurring earlier in the year as observed by Waibel et al. (2013) in the Deschutes Basin, Oregon.

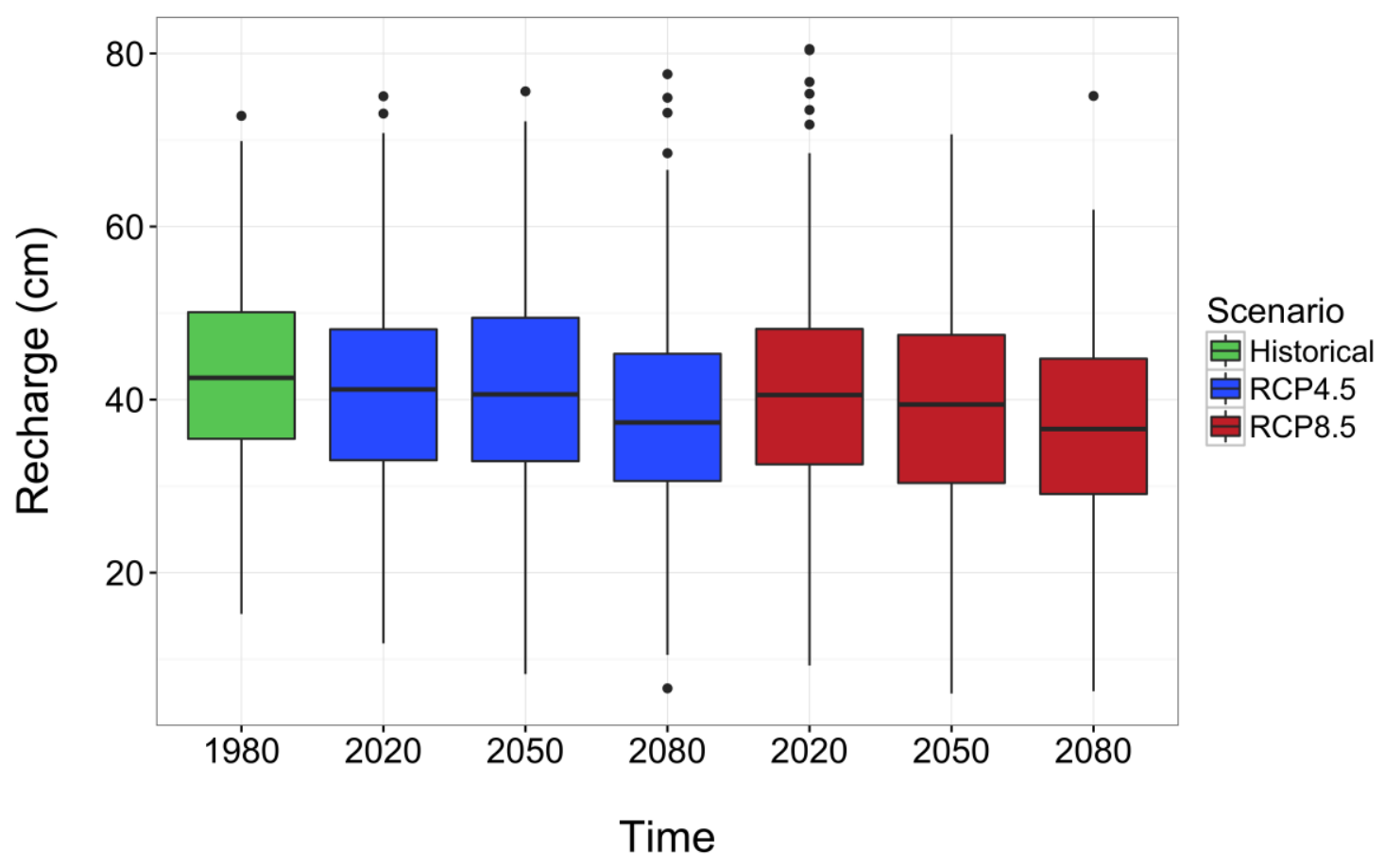

Figure 14: Cumulative ensemble mean basin recharge. 
Table 11: Cumulative mean and percent change in basin recharge.

\begin{tabular}{cc|ccc|ccc}
\hline & Hist. & \multicolumn{3}{c|}{ RCP4.5 } & \multicolumn{3}{c}{ RCP8.5 } \\
\hline & 1980s & 2020s & 2050s & 2080s & $2020 s$ & $2050 s$ & $2080 s$ \\
\hline $\begin{array}{c}\mu \text { Recharge } \\
(\mathrm{cm})\end{array}$ & 42.77 & 40.93 & 40.71 & 38.36 & 40.93 & 39.6 & 36.46 \\
\hline Min & 15.23 & 11.83 & 8.29 & 6.64 & 9.27 & 6.04 & 6.31 \\
Max & 72.79 & 75.05 & 75.62 & 77.61 & 80.51 & 70.65 & 75.09 \\
\hline$\Delta$ & & -4.30 & -4.82 & -10.31 & -4.30 & -7.41 & -14.75 \\
\hline
\end{tabular}

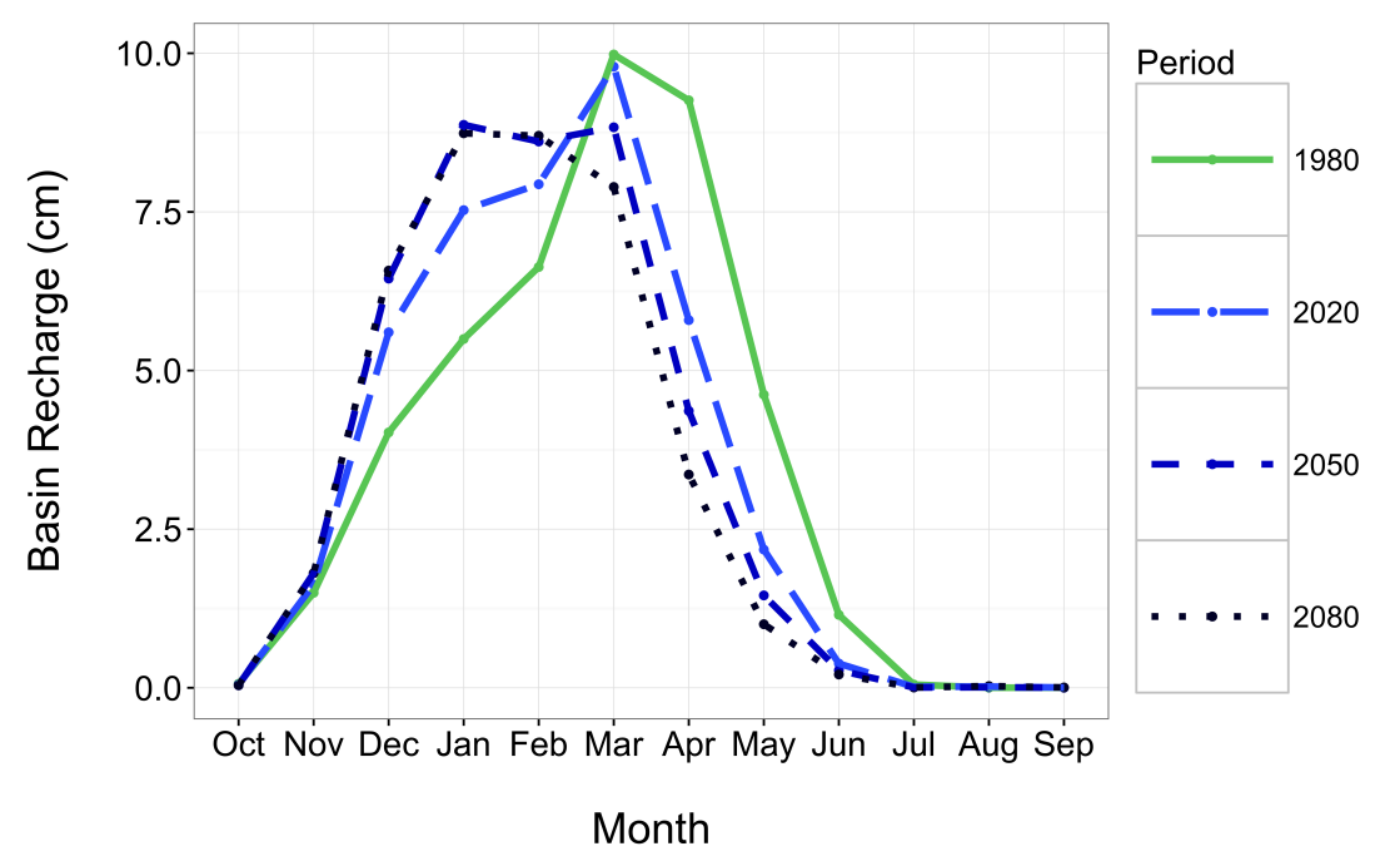

Figure 15: Ensemble mean for monthly basin recharge in the RCP 4.5 scenario. 


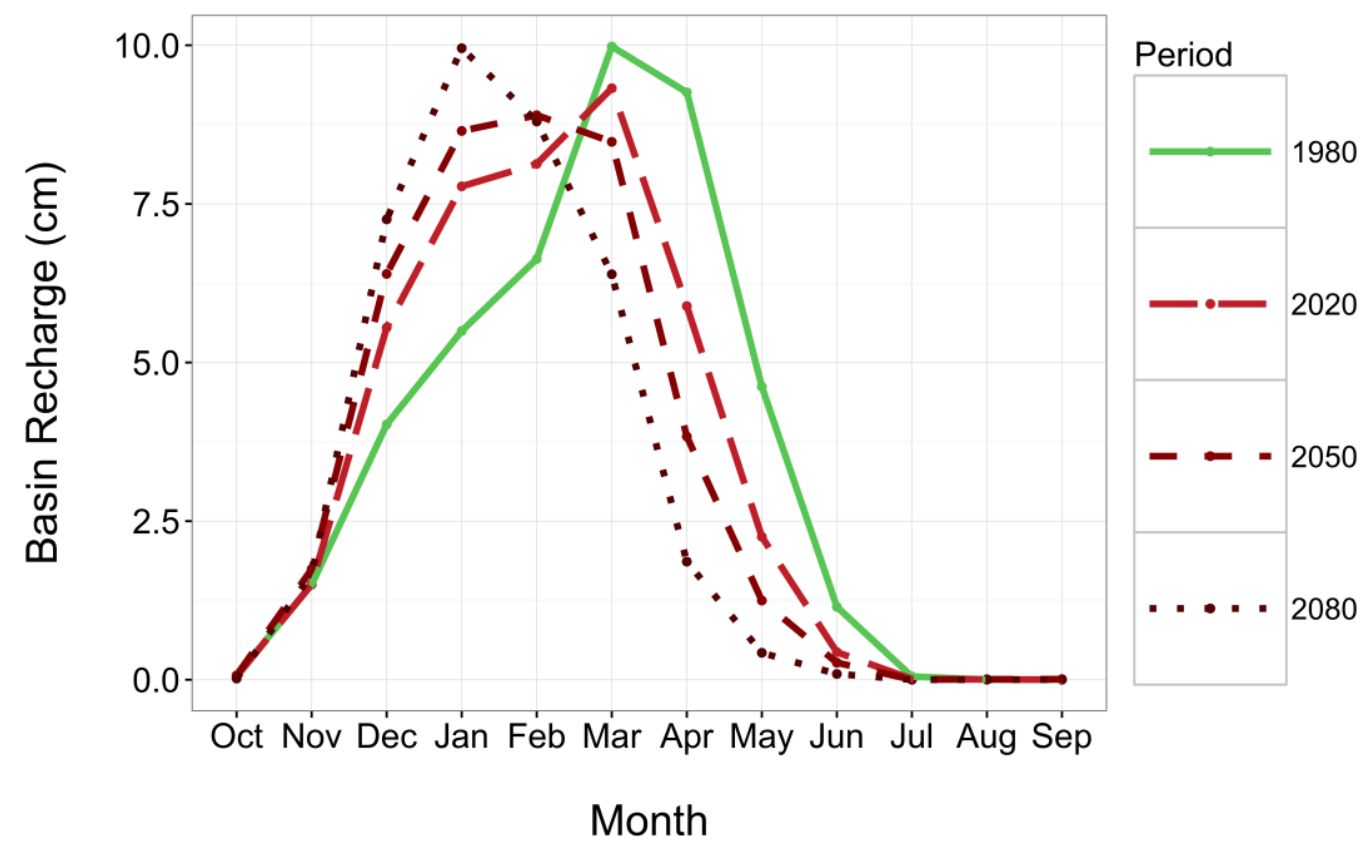

Figure 16: Ensemble mean for monthly basin recharge in the RCP 8.5 scenario Table 12: Mean monthly and perecent change in basin recharge.

\begin{tabular}{ll|lll|lll}
\hline & Hist. & \multicolumn{3}{c|}{ RCP4.5 } & \multicolumn{3}{c}{ RCP8.5 } \\
\hline & 1980s & 2020s & $2050 \mathrm{~s}$ & $2080 \mathrm{~s}$ & $2020 \mathrm{~s}$ & $2050 \mathrm{~s}$ & $2080 \mathrm{~s}$ \\
\hline$\mu$ Peak Recharge $(\mathrm{cm})$ & 9.98 & 9.79 & 8.87 & 8.74 & 9.32 & 8.9 & 9.95 \\
Month & Mar & Mar & Jan & Jan & Mar & Feb & Jan \\
$\% \Delta$ & & -1.90 & -11.12 & -12.42 & -6.61 & -10.82 & -0.30 \\
\hline
\end{tabular}




\section{Post-Fire Results}

\subsubsection{Center Time}

Land cover change analysis was completed using two GCMs, MIROC5 and HadGEM2-ES, before and after forest cover reduction (pre- and post-fire) in the 2050s and 2080s in the RCP 8.5 scenario. Mean CT, seasonal flows, SWE/P, basin recharge, mean monthly recharge, BFI, and COV of seasonal flows were determined. Mean CT in the 2050s before forest cover reduction occurred 38 days earlier than baseline conditions, and occurred 44 days earlier after forest cover reduction, a difference of six days in the 2050s before and after land cover change (Fig. 17; Table 13). In the 2080s, mean CT occurred 31 days before forest cover reduction, and occurred 35 days earlier than baseline conditions after forest cover reduction, a difference of 4 days between before and after forest cover reduction in the 2080 s (Table 13). Mean CT is significantly different between historical conditions and before and after forest cover reduction in both the 2050s and 2080s, but is not significantly different between the two land cover conditions within the 2050s and 2080s (See Appendix B). 


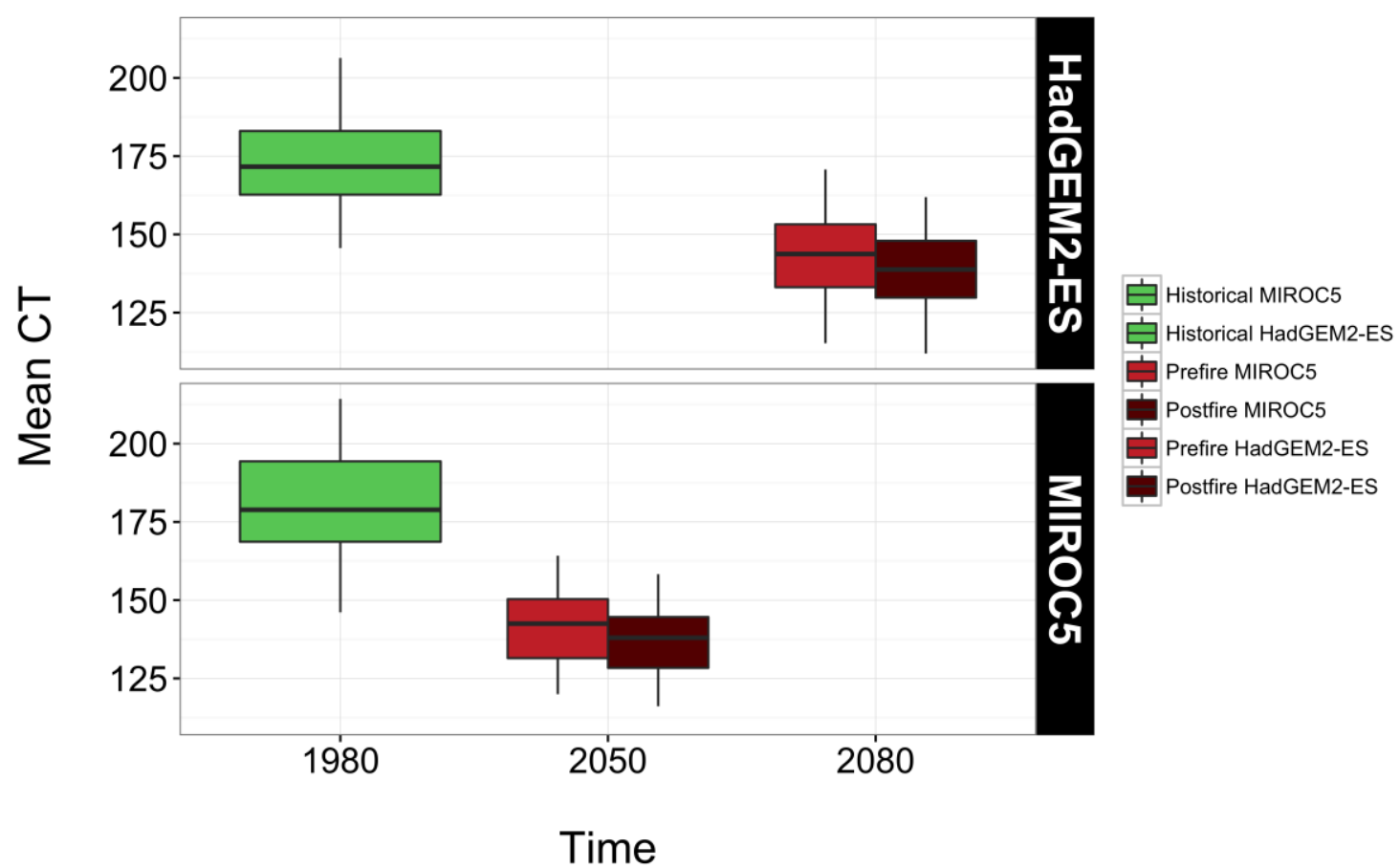

Figure 17: Mean Center Timing of flow for MIROC5 and HadGEM2-ES in the RCP 8.5 scenario before and after forest cover reduction.

Table 13: Mean CT before and after forest cover reduction in the RCP 8.5 scenario.

\begin{tabular}{llll|lll}
\hline \multicolumn{3}{c|}{ MIROC5 } & \multicolumn{3}{c}{ HadGEM2-ES } \\
\hline & Historical & Prefire & Postfire & Historical & Prefire & Postfire \\
& 1980s & 2050s & 2080s & 1980s & 2020s & 2080s \\
\hline $\begin{array}{l}\Delta \text { in days in } \\
\mu \text { CT }\end{array}$ & $(6 / 30)$ & 38d (5/23) & $44 d(5 / 17)$ & $(6 / 22)$ & 31d (5/22) & 35d (5/18) \\
\hline
\end{tabular}

\subsubsection{Seasonal Flows}

Winter runoff in the 2050 s showed a $133 \%$ increase before forest cover reduction and a 151\% increase after forest cover reduction (Fig. 18; Table 14). In the 2080s, winter runoff increases $80 \%$ before land cover change and increases 
$91 \%$ after land cover change (Table 14). Winter flows are significantly different between historical and both land cover conditions in the 2050s and 2080s, but is not significantly different between before and after forest cover reduction within the 2050s and 2080s (See Appendix B). A decrease in summer flows is observed for both before and after forest cover reduction. A 63\% decrease in both land cover conditions is observed in the 2050 s, and a $73 \%$ and $68 \%$ decrease before and after forest cover reduction in the 2080s (Fig. 18; Table 14). In the 2050s, summer runoff between historical and before and after forest cover reduction are significantly different, while there is no significant difference in the 2080s, between historical and before and after forest cover reduction ( $p$-value $=0.48)$ (See Appendix B). 


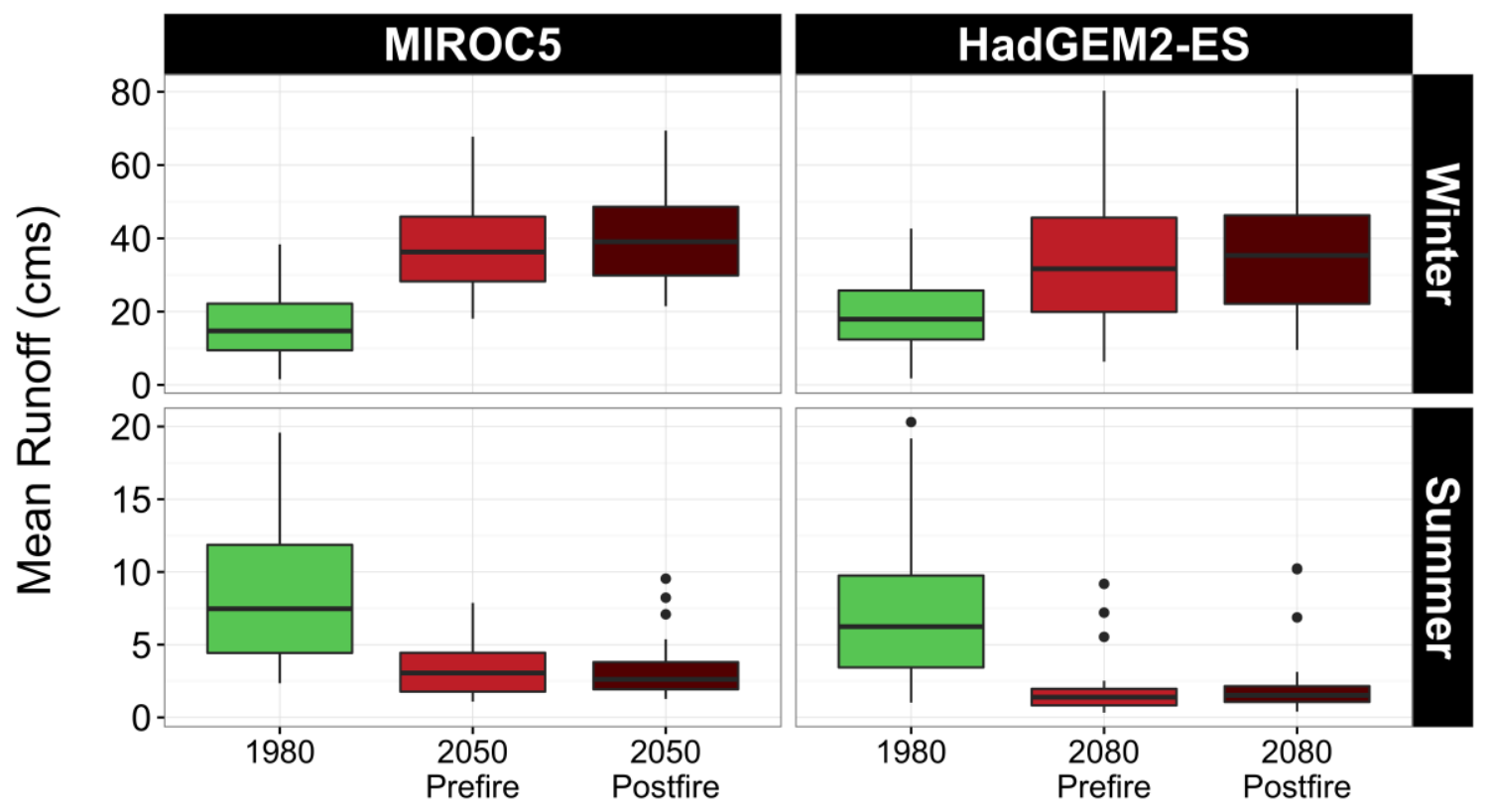

Time

Figure 18: Seasonal flows for MIROC5 and HadGEM2-ES in the RCP 8.5 scenario before and after forest cover reduction.

Table 14: Percent change of seasonal flows before and after forest cover reduction in the RCP 8.5 scenario (WTR=Winter; SMR=Summer).

\begin{tabular}{lllllll}
\hline \multicolumn{7}{c}{ MIROC5 } \\
\hline & 1980s & \multicolumn{3}{c}{ 2080s } & \multicolumn{3}{c}{ 2080s } \\
& Hist. & Prefire & & Postfire \\
\hline$\mu$ Runoff & WTR & SMR & WTR & SMR & WTR & SMR \\
$\left(\mathrm{cm}^{3} / \mathrm{s}\right)$ & 15.93 & 8.85 & 37.14 & 3.30 & 39.95 & 3.26 \\
$\operatorname{Min}$ & 1.54 & 2.34 & 18.07 & 1.08 & 21.48 & 1.27 \\
$\operatorname{Max}$ & 38.36 & 19.59 & 67.74 & 7.88 & 69.41 & 9.54 \\
$\% \Delta$ & & & 133.15 & -62.7 & 150.8 & -63.2
\end{tabular}

\begin{tabular}{lllllll}
\hline \multicolumn{7}{c}{ HadGEM2-ES } \\
\hline & 1980s & \multicolumn{3}{c}{ 2080s } \\
Pist. & \multicolumn{3}{c}{ Prefire } & 2080s \\
& Postfire \\
\hline$\mu$ Runoff & WTR & SMR & WTR & SMR & WTR & SMR \\
$\left(\mathrm{cm}^{3} / \mathrm{s}\right)$ & 18.94 & 7.12 & 33.92 & 1.93 & 36.13 & 2.31 \\
$\operatorname{Min}$ & 1.79 & 1.01 & 6.34 & 0.32 & 9.57 & 0.39 \\
$\operatorname{Max}$ & 42.67 & 20.31 & 80.30 & 9.18 & 80.86 & 10.24 \\
$\% \Delta$ & & & 79.1 & -72.9 & 90.8 & -67.6 \\
\hline
\end{tabular}




\subsubsection{Snow Water Equivalent/Precipitation}

The ratio of SWE to $\mathrm{P}$ is substantially lower in the 2050 s in comparison to the 1980 s with an $85 \%$ decrease before forest cover reduction and $90 \%$ decrease after forest cover reduction (Fig. 19; Table 15). The absolute difference is 0.088 and 0.094 , before and after forest cover reduction, in the 2050 s in comparison to the 1980s (Table 15). Between the two land cover conditions in the 2050 s, there is a $38 \%$ decrease in SWE/P (Table 15). In the 2080s, the ratio is significantly lower with a $99 \%$ decrease in both before and after forest cover reduction and an absolute difference in 0.073 in the 2080 s in comparison to historical conditions (See Appendix B). This is indicative of earlier snowmelt, winter runoff and decreased summer baseflow. This does not consider expected variability at different elevations and aspect. There is significant difference between both land cover conditions in comparison to historical conditions in the 
2050s and 2080s, and no significant difference between the 2050s and 2080s before and after forest cover reduction (See Appendix B).

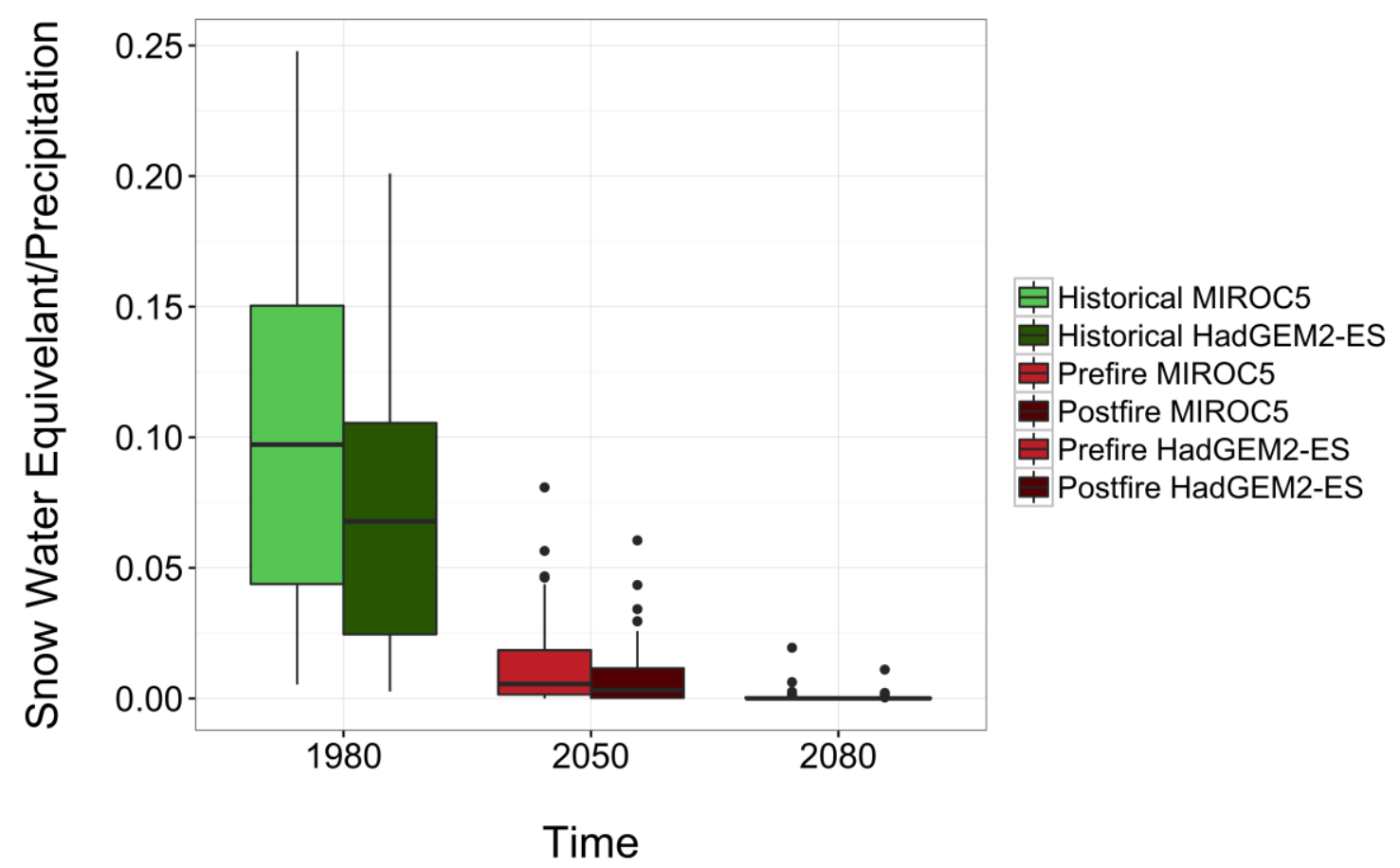

Figure 19: Ratio of snow water equivalent to precipitation before and after forest cover reduction in the RCP 8.5 scenario.

Table 15: Ratio of snow water equivalent to precipitation before and after forest cover reduction in the RCP 8.5 scenario.

\begin{tabular}{llll|lll}
\hline & \multicolumn{3}{c|}{ MIROC5 } & \multicolumn{3}{c}{ HadGEM2-ES } \\
\cline { 2 - 7 } & $\begin{array}{c}\text { Histor } \\
\text { ical }\end{array}$ & $\begin{array}{l}\text { Before } \\
\text { LCC }\end{array}$ & $\begin{array}{l}\text { After } \\
\text { LCC }\end{array}$ & Historical & $\begin{array}{l}\text { Before } \\
\text { LCC }\end{array}$ & $\begin{array}{l}\text { After } \\
\text { LCC }\end{array}$ \\
\hline & $\mathbf{1 9 8 0 s}$ & $\mathbf{2 0 5 0 s}$ & $\mathbf{2 0 5 0 s}$ & $\mathbf{1 9 8 0 s}$ & $\mathbf{2 0 8 0 s}$ & $\mathbf{2 0 8 0 s}$ \\
$\mu \mathrm{SWE}(\mathrm{cm})$ & 8.4 & 1.69 & 1.15 & 6.38 & $8.7 \mathrm{E}-02$ & $4.4 \mathrm{E}-02$ \\
$\mu \mathrm{P}(\mathrm{cm})$ & 77.2 & 88.61 & 88.61 & 76.96 & 79.89 & 79.89 \\
$\mu \mathrm{SWE} / \mathrm{P}$ & $1.04 \mathrm{E}-$ & & & & & \\
$\% \Delta$ & 01 & $1.6 \mathrm{E}-02$ & 0.01 & $7.4 \mathrm{E}-02$ & $1 \mathrm{E}-03$ & $5 \mathrm{E}-04$ \\
& & -84.6 & -90.4 & & -98.6 & -99.3 \\
\hline
\end{tabular}




\subsubsection{Potential Basin Recharge}

Cumulative potential basin recharge decreases in the 2050s and 2080s by $2 \%$ and $27 \%$ in comparison to historical conditions before forest cover reduction (Fig. 20; Table 16). After forest cover reduction, recharge increases $8 \%$ in the 2050s while in the 2080 s, it is $11 \%$ less than historical conditions (Table 16 ). Basin recharge is not significantly different between historical conditions and both before and after forest cover reduction in the 2050s ( $p$-value=0.38) (See Appendix B). In the 2080s, recharge is significantly different between the 1980 s and before forest cover reduction, and not significantly different between the 1980s and after forest cover reduction, and not significantly different between both land cover conditions in the 2080s (See Appendix B). Recharge is expected to decrease with increased runoff due to decreased interception, and sublimation of snow from tree or vegetation (Konrad et al., 2014), however there is an increase in recharge in the 2050s after forest cover reduction by $4 \mathrm{~cm}$ in comparison to historic conditions (Table 16). Improved characterization of aquifer recharge in the CRBGs would offer further insight. 


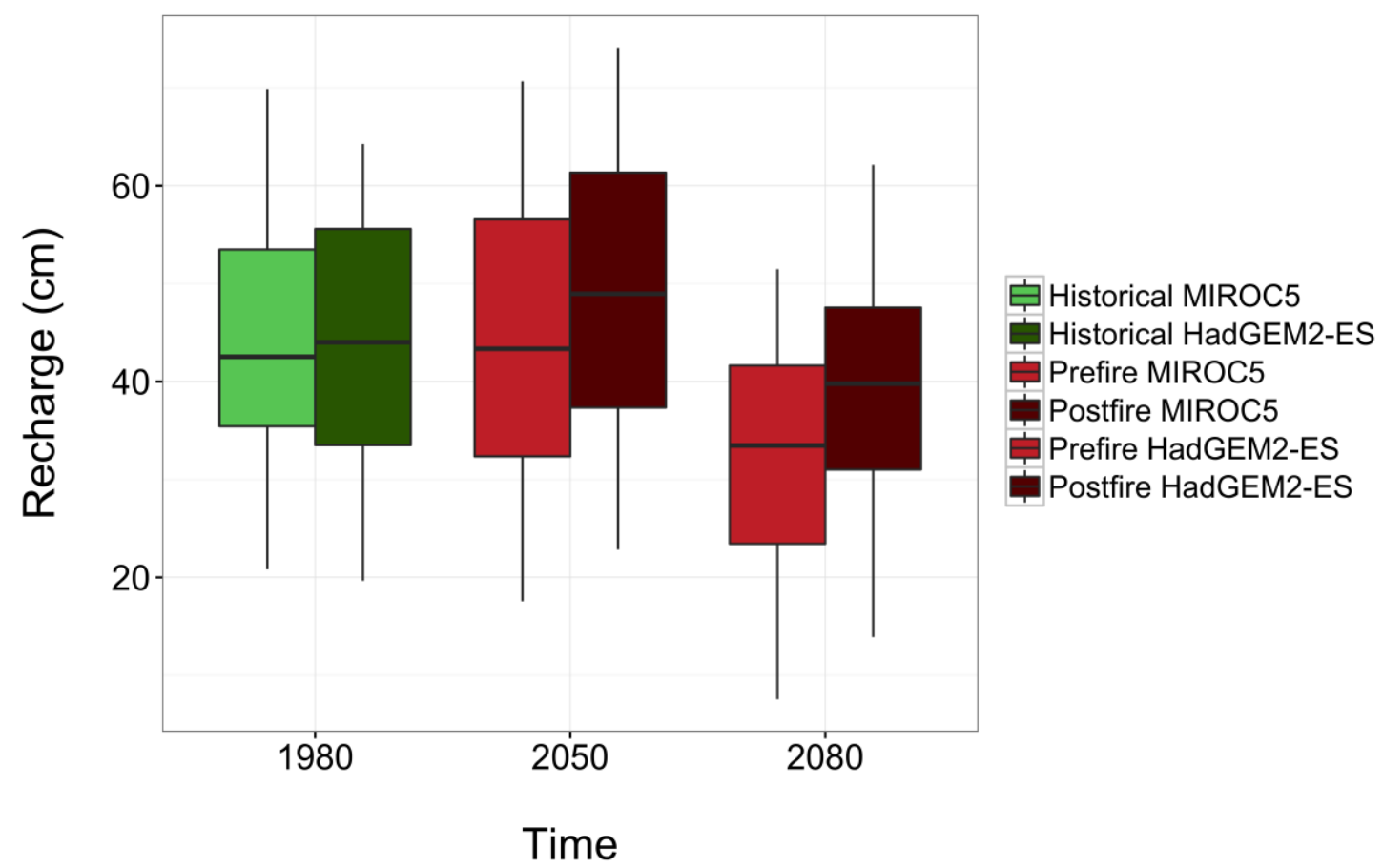

Figure 20: Mean basin recharge before and after forest cover reduction.

Table 16: Percent change of mean basin recharge before and after forest cover reduction.

\begin{tabular}{|c|c|c|c|c|c|c|}
\hline & \multicolumn{3}{|c|}{ MIROC5 } & \multicolumn{3}{|c|}{ HadGEM2-ES } \\
\hline & $\begin{array}{c}\text { Historical } \\
1980 \mathrm{~s}\end{array}$ & $\begin{array}{l}\text { Before } \\
\text { LCC } \\
2050 s\end{array}$ & $\begin{array}{l}\text { After } \\
\text { LCC } \\
2050 \text { s }\end{array}$ & $\begin{array}{c}\text { Historical } \\
1980 \text { s }\end{array}$ & $\begin{array}{l}\text { Before } \\
\text { LCC } \\
2080 \text { s }\end{array}$ & $\begin{array}{l}\text { After } \\
\text { LCC } \\
2080 \text { s }\end{array}$ \\
\hline$\mu$ Recharge & 44.55 & 43.47 & 48.31 & 43.73 & 32.14 & 38.99 \\
\hline Min & 20.82 & 17.56 & 22.84 & 19.65 & 7.56 & 13.9 \\
\hline Max & 69.88 & 70.65 & 74.09 & 64.26 & 51.48 & 62.13 \\
\hline$\% \Delta$ & & -2.42 & 8.44 & & -26.5 & -10.84 \\
\hline
\end{tabular}

In the 2050s, peak basin recharge occurs in April in historical conditions $(11 \mathrm{~cm})$, and then occurs in January, decreasing $8 \%(10.3 \mathrm{~cm})$ and $4 \%(10 \mathrm{~cm})$ in recharge before and after forest cover reduction (Fig. 21; Table 17). Peak mean recharge in the 2080s, occurs in March $(10.3 \mathrm{~cm})$ in historic conditions and shifts 
to January decreasing $17 \%(9 \mathrm{~cm})$ and $10 \%(9.2 \mathrm{~cm})$, before and after forest cover reduction(Fig. 22; Table 17).

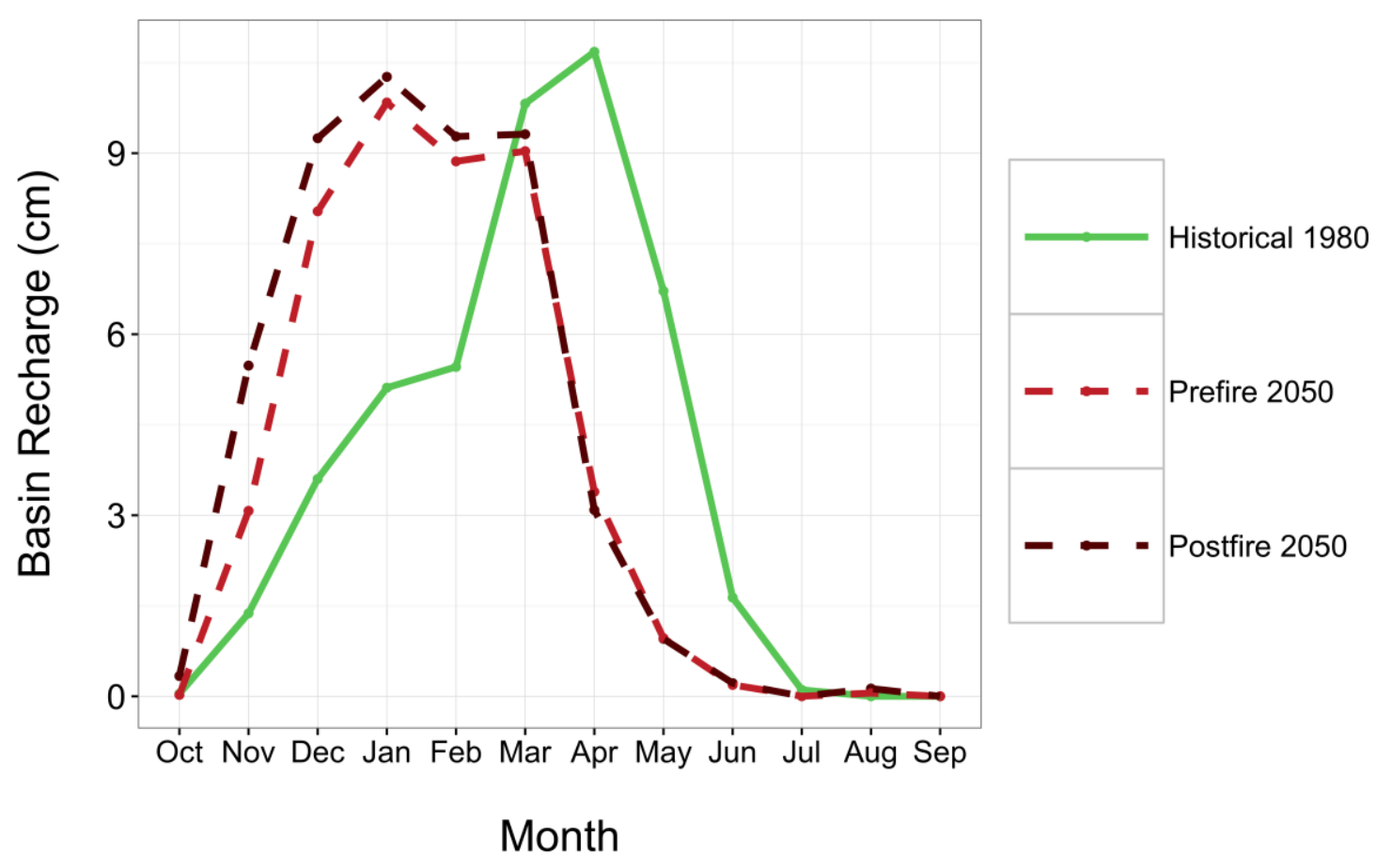

Figure 21: Mean basin monthly recharge for MIROC5 before and after forest cover reduction. 


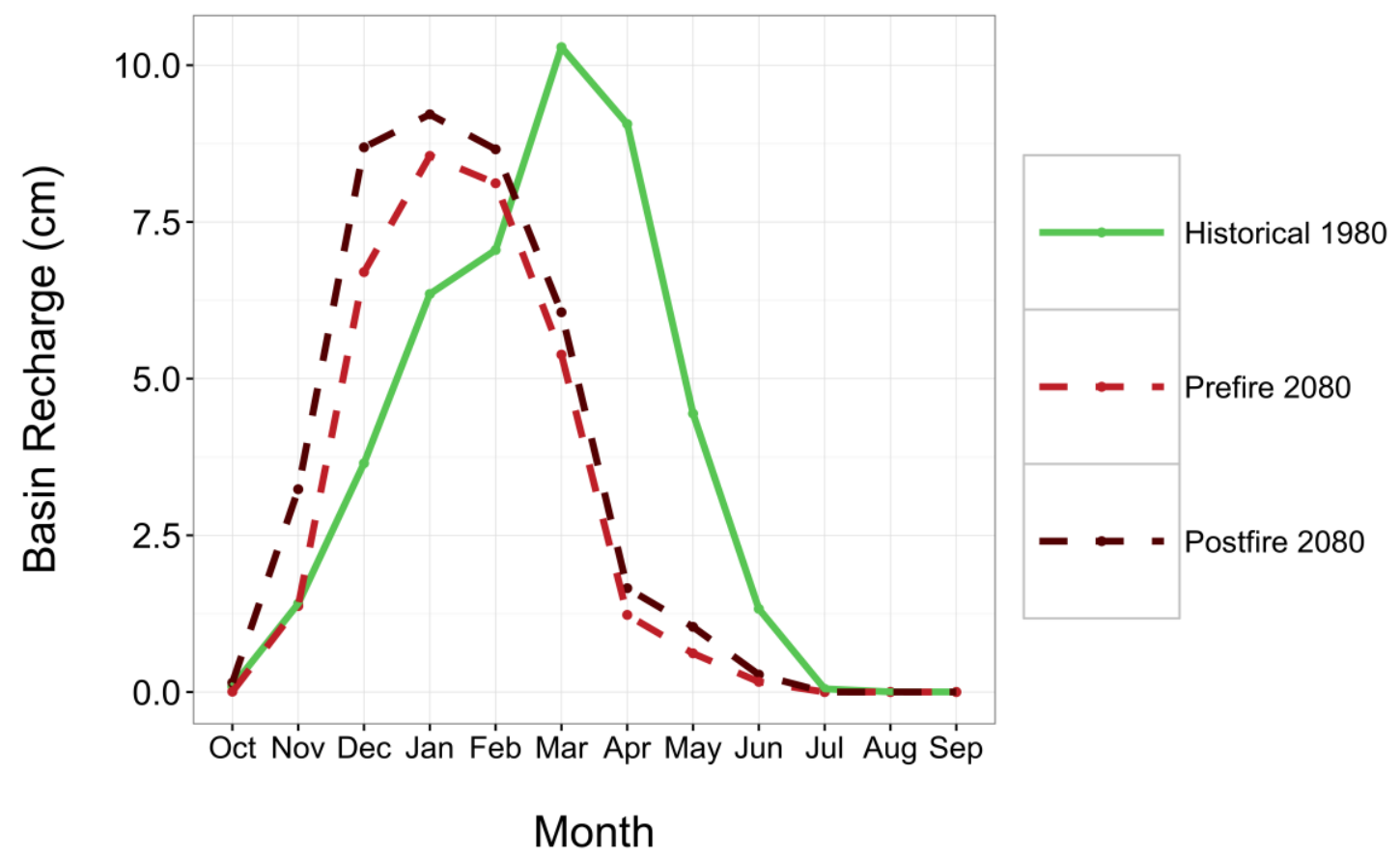

Figure 22: Mean basin monthly recharge for HadGEM2-ES before and after forest cover reduction.

Table 17: Peak mean basin recharge and peak month

\begin{tabular}{lccc|ccc}
\hline & \multicolumn{3}{c|}{ MIROC5 } & \multicolumn{3}{c}{ HadGEM2_ES } \\
\cline { 2 - 7 } & Historical & $\begin{array}{c}\text { Before } \\
\text { LCC }\end{array}$ & $\begin{array}{l}\text { After } \\
\text { LCC }\end{array}$ & Historical & $\begin{array}{c}\text { Before } \\
\text { LCC }\end{array}$ & $\begin{array}{c}\text { After } \\
\text { LCC }\end{array}$ \\
\hline$\mu$ mo. Recharge $(\mathrm{cm})$ & 10.68 & 9.84 & 10.27 & 10.29 & 8.55 & 9.22 \\
Peak mo. & April & January & January & March & $\begin{array}{c}\text { Januar } \\
\text { " }\end{array}$ & January \\
$\% \Delta$ & & 7.87 & 3.84 & & 16.91 & 10.40 \\
\hline
\end{tabular}

\subsubsection{Base-Flow Index}

Groundwater discharge to surface flow was determined by the BFI, the ratio of base flow to total stream flow. In the 1980 s, mean BFI determined $72 \%$ groundwater contributions to surface flows (Table 18). This is sustained throughout the $21^{\text {st }}$ century for all GCMs before forest cover reduction, dropping slightly to $69 \%$ for both scenarios at the end of the century (Table 18). After 
forest cover reduction, MIROC5 predicts $70 \%$ groundwater contributions for both land cover conditions, a 3-5\% decrease, while HadGEM2-ES predicts $67 \%$ and $66 \%$ groundwater contributions in both land cover conditions, a $13 \%$ increase from historical conditions (Appendix B). Before and after land cover change, there is minimal change under $5 \%$, whereas in the 2080 s after forest cover reduction, $\mathrm{BFI}$ increases by $13 \%$ at the end of the century (Table 18). This is individual model performance, and may vary across each GCM.

Table 18: Base-flow Index (BFI) and percent change before and after forest cover reduction.

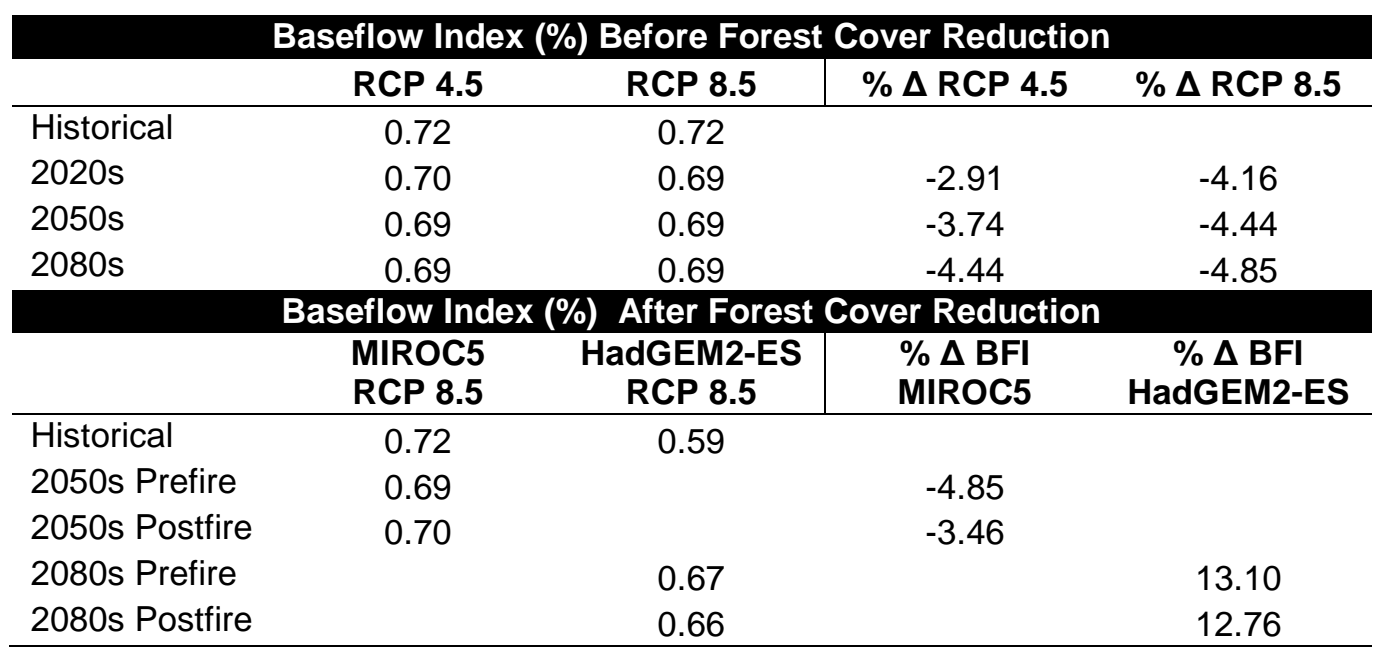

\subsubsection{Coefficient of Variation}

High variability across the GCMs is generally observed in the summer months in both scenarios before forest cover reduction, where it is highest in the 2020s and 2050s in the RCP 8.5 scenario (Fig. 23). In the winter, variability is higher in the historical period for both RCP 4.5 and RCP 8.5, where higher uncertainty or wider range of GCM performance would result in a smaller mean and higher CV 
value (Fig. 23). After forest cover reduction, variability is higher in the summer and increasingly in the 2005s and 2080s in RCP 8.5 (Fig. 24) In the winter after forest cover reduction, uncertainty is highest in the 2050s in RCP 4.5 (Fig. 24). In general, there is more certainty or increased confidence in GCM prediction of winter flows mid-century and onward.

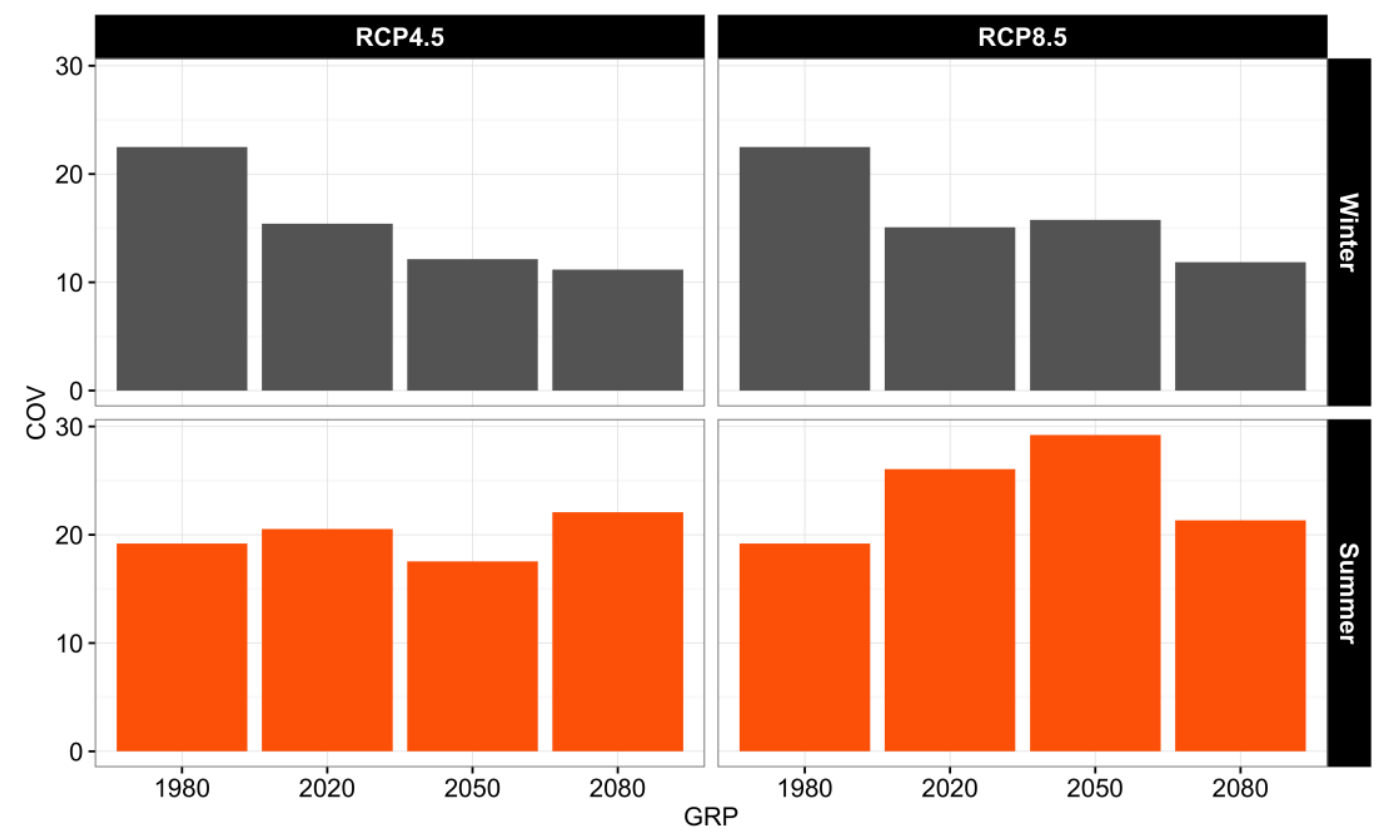

Figure 23: Coefficient of Variation of seasonal flows before forest cover reduction. 


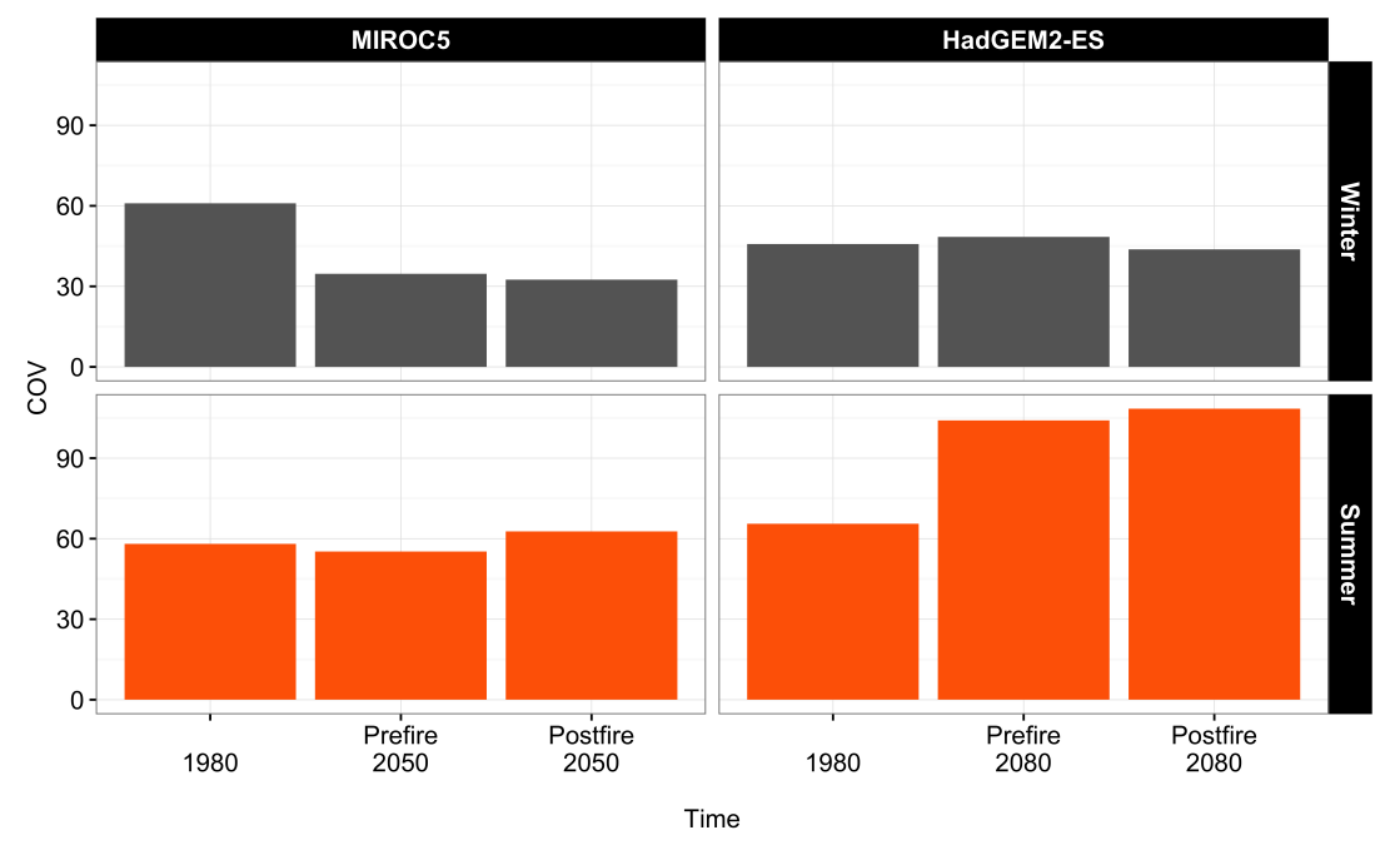

Figure 24: Coefficient of Variation of seasonal flows after forest cover reduction. 


\section{Discussion}

Model calibration may have been improved with a second stream gage with continuous historic flow available upstream on Meacham Creek, a tributary to the Umatilla River that provides a little over $50 \%$ of summer flows (CTUIR 2012). This would have required a second calibration for this drainage area and could be explored in future work. Consumptive use, which includes irrigation, municipal, and all other uses, such as domestic needs (Cooper 2002), was not calculated and deemed negligible because diversions at the USGS stream gage, Umatilla River West Reservation Boundary Near Pendleton, is minimal to total volume of streamflow. (Kate Ely, personal communication, April 23, 2013).

The temporal and spatial behavior of groundwater in a heterogeneous geologic structure of the CRBGs could not be delineated with PRMS alone and is outside the scope of this study. The CRBGs as a part of the CPRAS covers $70,811 \mathrm{~km}^{2}$ and warrants a regional approach in understanding groundwater behavior (Cherkauer, 2004). By choosing to use PRMS, an assumption was made that the hydrogeology in the study area is similar to an unconfined groundwater system (Cherkauer 2004). Another assumption was made in calculating BFI, where well withdrawal is negligible to total flows (Cherkauer 2004).

\subsubsection{Temperature and Precipitation}

A projected warming rate in the western U.S. is $0.1-0.6^{\circ} \mathrm{C} /$ decade (Dickerson-Lange \& Mitchell, 2014). In the URB, there is high uncertainty and 
variability across the GCMs as can be seen in the wide variation of temperature and precipitation change and increase in each time period in the $21^{\text {st }}$ century (Fig. 9). Mean temperature increases $3.3^{\circ} \mathrm{C}$ by the end of the century in RCP 8.5 , similar to $\mathrm{a}+3.2^{\circ} \mathrm{C}$ increase by the 2080 s predicted by Chang \& Jung (2010) in the Willamette River, OR. Dickerson-Lange and Mitchell (2014) predicted a 1.8 to $3.5^{\circ} \mathrm{C}$ mean increase in spring and summer temperatures by the 2050 s in one scenario in Northwestern Washington. Precipitation is variable in summer flows, and increases as much as $11.3 \%$ in RCP 8.5 by the end of the century in the URB (Fig. 9, Table 6), where a $15-21 \%$ increase is seen in northwestern WA in two models (Dickerson-Lange \& Mitchell, 2014). This is in agreement with Vynee et al. (2010), who observed approximately a $10 \%$ to $18 \%$ increase in precipitation by mid and end of the century in the URB. With increased temperatures and less snow to hold increased precipitation, the frequency and magnitude of floods is predicted to increase (Dickerson-Lange et al., 2014). It will become more important to understand temperature and precipitation trends, two primary factors in determining the timing and magnitude of streamflow in western rivers.

\subsubsection{Snow Water Equivalent and Precipitation}

April $1^{\text {st }}$ SWE is a function of winter accumulation and ablation. There is a clear pattern that SWE substantially decreases with each time period, indicating a hydrologic regime shift from a snow-rain dominant to rain-dominant basin. This is consistent with predictions in the Pacific Northwest (Stewart et al. 2005, Mote et al. 2005, Hamlet 2011; Jung \& Chang, 2011; Safeeq et al. 2013; Dickerson- 
Lange et al. 2014). Vynee et al. (2010) predicted SWE to decrease $>50 \%$ by the 2080 s in the URB. A considerable change in basin area-weighted SWE has been observed to affect mid-elevation areas in the rain and snow transition zone (Mastin, 2011). In post-fire conditions, there is a substantial decrease in SWE in the 2080s for both land cover conditions. This could be due to varying energybalances at the land and atmosphere interface, including radiative fluxes and changes in albedo, which can significantly influence melting snow rate and the intensity of reflection by snow cover. Albedo was observed to be higher after a forest fire and lower after afforestation (Oris et al., 2014). Warming trends and increased precipitation should be observed to see at what elevations or aspects, snowpack contributes to aquifer recharge and summer baseflow. Analysis of montane snowpacks that store winter precipitation and provide water for the rest of year is required for adaptation planning in dam releases and flood control (Molotch et al., 2004; Jepsen, 2012).

\subsubsection{Runoff Behavior}

Precipitation and temperature are the main drivers of the magnitude and timing of streamflow (Dickerson-Lange \& Mitchell, 2014). At the end of the $21^{\text {st }}$ century, before forest cover reduction, mean CT occurs earlier in the year by 4.7 weeks. There is more variability in mean CT after forest cover reduction, which may be a result of individual model behavior. Post-fire parameters including an $80 \%$ decrease in both summer and winter cover density, and a $40 \%$ increase in the solar radiation transmission coefficient (Table 2) may have more effect on 
peak discharge during individual precipitation events than $\mathrm{CT}$, a day in the water year half the runoff has occurred. Runoff trends even if subtle, can be detrimental to fish habitat and growing seasons of wheat and green peas in the URB, for instance.

Seasonal flows in comparison to baseline conditions are predicted to change with each successive time period, where winter flows show an increase as great as $98 \%$ and summer flows a decrease as low as $66 \%$ at the end of the century before forest cover reduction (Table 9). The same holds true after forest cover reduction, with a greater increase in winter flows by $150 \%$ in the 2050 s and $91 \%$ in the 2080s (Table 14). An increase in the ratio of winter rainfall to winter snowfall is observed here, where precipitation is not being held in the snowpack due to warming temperatures as seen across the western United States. In the region, Jung \& Chang (2011) observed negative runoff trends in the spring and summer, and positive trends in the fall and winter in the Willamette River Basin. Similarly, Dickerson-Lange (2014) observed increases in winter discharge from 34 to $60 \%$ by midcentury and decreases in summer flows from -20 to $-30 \%$ in Northwestern, WA. In the Deschutes Basin in central Oregon, winter flows are projected to increase 80 to $115 \%$ in the Cascade Range (Waibel et al., 2013).

\subsubsection{Potential Basin Recharge \& Base-flow}

Contrary to a substantial decrease in SWE/P, mean basin recharge is projected to remain within range of historic levels with slight declines throughout the $21^{\text {st }}$ century, with the exception of a sudden decrease in the 2080s for both 
scenarios before forest cover reduction. Basin recharge estimates range from 36$41 \mathrm{~cm} / \mathrm{yr}$, within range of previous studies of 2.0 to $36.0 \mathrm{~cm} / \mathrm{yr}$ (Spane \& Weber, 1995; Bauer \& Vaccaro, 1990; Brown 2009). After forest cover reduction, mean recharge increases and is greater than historic levels in the 2050s. This is based on individual model performance, otherwise a decrease would be expected due to a reduction of soil porosity and the formation of hydrophobic soils after a fire, reducing infiltration rates. Potential mean recharge for the CPRAS is estimated to be $11.6 \mathrm{~cm} / \mathrm{yr}$ (Burns et al. 2012). Similar to potential basin recharge, groundwater contributions to surface flow is projected to be sustained where the $\mathrm{BFI}$ remains within historic levels with slight declines in both RCP 4.5 and RCP 8.5 scenarios before forest cover reduction, and in the 2050s after forest cover reduction. With the exception of a $13 \%$ increase in groundwater contributions to surface flows in the 2080s as predicted by HadGEM2-ES after forest cover reduction, this may be due to the predicted substantial increase in precipitation and increased winter runoff in the 2080s. Again, predictions vary by GCM and the ensemble mean could be different.

The decline of groundwater levels in the URB has been addressed by The City of Pendleton, where the Aquifer Storage and Recovery program (ASR) lowered the city's dependence on groundwater from $62 \%$ to $3 \%$. Since then, groundwater declines were observed to be $340 \mathrm{~cm} / \mathrm{year}$ and down to $200 \mathrm{~cm} / \mathrm{yr}$ after ASR has been implemented in 2004 (Pendleton Public Works, Water Division, 2012). 


\subsubsection{Future Work}

A significant next step would be to characterize at different spatial and temporal scales, the behavior of ground- and surface-water interactions using a numerical groundwater model and further analyze the effects of fire on runoff with a landscape simulation model. A dynamic global vegetation model may help identify parameters that account for regrowth, fire type and intensity, to improve understanding of the effects of fire-burns on a watershed system. Soil water repellence for example, has been found to last anywhere from one to six years, where a shorter temporal scale may best capture watershed response to fire (Henderson \& Golding, 1983; Macdonald \& Huffman, 2004). PRMS files may be adapted to combine with MODFLOW, a numerical groundwater model, to input to GSFLOW, a coupled groundwater and surface-water flow model, to increase understanding of the spatial and temporal behavior of groundwater. In addition, spatial analysis at a finer scale of water budget variables according to aspect and elevation will only enhance localized efforts for management of ecosystem services. 


\section{Conclusions}

Increasing global mean temperature and changing precipitation are driving factors in runoff behavior. The uncertainty in the affects of climatic change and variability, and anthropogenic influences on a hydrologic regime makes it imperative to study their effects on natural resources. Using PRMS, a runoff model was calibrated for the upper URB, to characterize trends in runoff, snowpack, recharge, and other components of the water budget to understand water availability in changing climate and forest cover reduction. The effects of fire and climate shifts on runoff behavior, is largely understudied in the URB making this study unique.

A hydrologic regime shift is observed in the URB, from a snow-rain dominated to rain-dominated basin. Increased winter flows and decreased summer flows are predicted throughout the $21^{\text {st }}$ century. By the end of the century, a $1.6^{\circ} \mathrm{C}$ increase in RCP 4.5 and $3.3^{\circ} \mathrm{C}$ increase in RCP 8.5 in basin temperature is observed. With increasing temperatures, less precipitation is held in the snowpack and peak basin runoff occurs earlier in the year in both land cover conditions, with decreased summer flows throughout the $21^{\text {st }}$ century. This is amplified in winter flows in the RCP 8.5 scenario mid-century and onward. The ratio of SWE/P is shown to significantly decrease in both scenarios across the century before forest cover reduction. After forest cover reduction, similar trends in mean $\mathrm{CT}$, seasonal flows and SWE/P, are observed with a substantial decrease in SWE/P by the 2080s and increase in winter flows in the 2050s. 
Mean basin recharge is sustained throughout the 21 st century with slight declines in each subsequent time period before forest cover reduction, while after post-fire simulation, basin recharge increases. Similarly, groundwater contributions is predicted to remain constant with slight declines throughout the 21 st century before forest cover reduction, and a 13\% decline in RCP 8.5 after forest cover reduction. Due to the complexity of groundwater behavior in the CRBGs, basin recharge should be explored further with a numerical groundwater flow model.

This study provides further insight to secure freshwater resources for ecosystem function and cultural resources in the URB. It is a viable method in which to improve adaptive capacity, including flood control, dam releases, and instream flow restoration practices. Collaborative partnerships across the region with entities such as CTUIR, the Columbia Basin Ground Water Management Area, and U.S. Forest Service will only improve resource assessments and plan for extreme climatic events.

The methods used in this study are adaptable and replicable in western watershed basins where temperature and precipitation are the driving factors of runoff behavior, and snow water equivalent is a sensitive, strong indicator of a changing hydrologic regime. The ensemble mean change provides a consensus of trend, variability and range of GCM projections (Mote et al., 2011). In the face of climate uncertainty, watershed modeling proves to be a valuable tool in 
identifying runoff trends to assist in making informed water management decisions and can only strengthen climate preparedness. 


\section{Reference Section}

Abatzoglou, J. (2013). Development of gridded surface meteorological data for ecological applications and modelling. International Journal of Climatology, 33(1), 121-131.

Abatzoglou J.T. and Brown T.J. (2012). "A comparison of statistical downscaling methods suited for wildfire applications " International Journal of Climatology. doi: 10.1002/joc.2312.

Abatzoglou, J.T, Rupp, D., \& Mote, P. (2014). Understanding seasonal climate variability and change in the Pacific Northwest of the United States. Journal of Climate, 27. doi: 10.1175/JCLI-D-13-00218.1

Abatzoglou, J. T. (2011), Influence of the PNA on declining mountain snowpack in the Western United States. Int. J. Climatol., 31: 1135-1142.

doi:10.1002/joc.2137

Anonymous. (2010). CTUIR team to develop water rights strategy. Confederated Umatilla Journal, p. 31,41.

Bathurst, J. (1997). Contemporary hydrology: Towards holistic environmental science: By R.L. Wilby (Editor), John Wiley and Sons, Chichester, UK, 1997. Hardcover, XIII 354 pp, Price £34.95, ISBN 0-471-96636-3. Journal of Hydrology,201(1), 151-193.

Battin, J., Wiley, M., Ruckelshaus, M., Palmer, R., Korb, E., Bartz, K., \& Imaki, H. (2007). Projected Impacts of Climate Change on Salmon Habitat

Restoration.Proceedings of the National Academy of Sciences of the United States of America, 104(16), 6720-6725.

Bauer, H.H., and Vaccaro, J.J. (1987). Documentation of a Deep Percolation Model for estimating ground-water recharge: U.S. Geological Survey Ope-File Report 86-536.

Bauer, H.H., and Vaccaro, J.J. (1990). Estimates of groundwater recharge to the Columbia Plateau regional aquifer system, Washington, Oregon, and Idaho, for predevelopment and current land0use conditions: U.S. Geological Survey Water Resources Investigations Report 88-4108.

Bauer, H., \& Hansen, A.J. (2000). Hydrology of the Columbia Plateau Regional Aquifer System, Washington, Oregon, and Idaho (Water-resources investigations report ; 96-4106). Tacoma, Wash. : Denver, Colo.: U.S. Dept. of the Interior, U.S. Geological Survey ; U.S. Geological Survey, Information Services [distributor]. 
Board of Trustees, Confederated Tribes of the Umatilla Indian Reservation. (2010). "Comprehensive Plan, Confederated Tribes of the Umatilla Indian Reservation."

Brown, K., McIntosh, Jennifer, Baker, Victor, Lohse, Kathleen, \& Ferre, Ty. (2009). The Effects of past Climate Change and Recent Agricultural Irrigation Recharge on the Sources, Ages, and Quality of Groundwater in the Columbia River Basalt Aquifers, Columbia Basin, Central Washington, ProQuest Dissertations and Theses.

Burns, E., Groundwater Resources Program, \& Oregon. Water Resources Department, sponsoring body. (2012). Groundwater status and trends for the Columbia Plateau Regional Aquifer System, Washington, Oregon, and Idaho(Scientific investigations report ; 2012-5261). Reston, Virginia: U.S. Department of the Interior, U.S. Geological Survey.

Cerda, A. (1998). Post-fire Dyamics of Erosional Processes under Mediterranean Climatic Conditions. Zeitschrift feur Geomorphologie Neue Folge 42(3):373-398

Chalise, D.R. (2013). Evaluating Temporal and Spatial Scale Issues with Hydrologic Models in the Black Hills, South Dakota, Thesis. Rapid City, SD: South Dakota School of Mines and Technology. Retrieved from: http://Users/Hydrologist/Downloads/MS\%20Thesis\%20Main\%20Voume\%20(1). $\underline{\text { pdf }}$

Chang H.J., Jung I.W. (2010). "Spatial and temporal changes in runoff caused by climate change in a complex large river basin in Oregon". J. Hydrol. 388:186207.

Chang, H., Evans, B., \& Easterling, D. (2001). The effects of climate change on stream flow and nutrient loading. Journal Of The American Water Resources Association, 37(4), 973-985.

Chang, Heejun, \& Psaris, Mike. (2013). Local landscape predictors of maximum stream temperature and thermal sensitivity in the Columbia River Basin, USA. The Science of the Total Environment, 461 462, 587.

Cherkauer, D. (2004). Quantifying Ground Water Recharge at Multiple Scales Using PRMS and GIS. Ground Water, 42(1), 97-110.

Choi, W. (2008). Catchment-scale hydrological response to climate-land-use combined scenarios: A case study for the Kishwaukee River basin, Illinois. Physical Geography, 29(1), 79-99. 
Christensen, N., Wood, A., Voisin, N., Lettenmaier, D., \& Palmer, R. (2004). The effects of climate change on the hydrology and water resources of the Colorado River basin. Climatic Change, 62(1-3), 337-363.

Christiansen, D.E., Markstrom, S.L., Hay, L.E. (2011). "Impafcts of Climate Change on the Growing Season in the United States". Earth Interact., 15, 1-17.

Christensen, G., \& Pacific Northwest Research Station. (2007). Forest resources of the Umatilla National Forest (Resource bulletin PNW ; 253). Portland, OR: U.S. Dept. of Agriculture, Forest Service, Pacific Northwest Research Station.

Cooper, Richard M. (2002). Determining Surface Water Availability in Oregon, State of Oregon Water Resources Department, Open File Report SW 02-002.

Confederated Tribes of the Umatilla Indian Reservation. (2012). "Meacham Creek Flood Restoration and In-stream Enhancement Project Completion Report". Tetra Tech Inc. Publication, Portland, OR.

Confedrated Tribes of the Umatilla Indian Reservation. (2010). "Forest Management Plan: An Ecological Approach to Forest Management". Mason Bruce \& Gerard, Inc. Publication, Bothell, WA.

Confederated Tribes of the Umatilla Indian Reservation, (2007). "Groundwater Study of the Columbia River Basalt Aquifer Umatilla Indian Reservation, Umatilla County, Oregon." [Technical Report]

Daly, C., Halbleib, M., Smith, J., Gibson, W., Doggett, M., Taylor, G., . . . Pasteris, P. (2008). Physiographically sensitive mapping of climatological temperature and precipitation across the conterminous United States. International Journal of Climatology, 28(15), 2031-2064.

Davies-Smith, A., Bolke, E.L., and Collins, C.A. (1988). "Geohydrology and Digital Simulation of the Ground-Water Flow System in the Umatilla Plateau and Horse Heaven

DeBarry, P. (2004). Watersheds : Processes, assessment, and management. Hoboken, N.J.: Wiley.

Dickerson-Lange, S., \& Mitchell, R. (2014). Modeling the effects of climate change projections on streamflow in the Nooksack River basin, Northwest Washington. Hydrological Processes, 28(20), 5236-5250.

Doummar, J., Sauter, M., \& Geyer, T. (2012). Simulation of flow processes in a large scale karst system with an integrated catchment model (Mike She) - 
Identification of relevant parameters influencing spring discharge. Journal Of Hydrology, 426, 112-123.

Drost, B., Whiteman, K. J, \& Washington . Department of Ecology. (1986).

Surficial geology, structure, and thickness of selected geohydrologic units in the Columbia Plateau, Washington (Water-resources investigations report ; 844326). Tacoma, Wash.: The Survey.

Elsner, M., Cuo, L., Voisin, N., Deems, J., Hamlet, A., Vano, J., . . Lettenmaier, D. (2010). Implications of 21 st century climate change for the hydrology of Washington State. Climatic Change, 102(1-2), 225-260.

Ely, K. (2001). "Water Resources Status, A Study of the Water Resources Availability and Demand in the Umatilla River Basin, Oregon." Report for U.S. Bureau of Indian Affairs.

Ely, K. (2012, August 01). Groundwater and Surface Water Are they related? Confederated Umatilla Journal, p. 31.

Flanagan, C., Laituri, M. "Environmental Assessment, Local Cultural Knowledge and Water Resource Management: The Wind River Indian Reservation." Environmental Management 33.2 (2004): 262-270

Fletcher, R., Lazinka, B., Newston, J., Wahner, G., Harris, J., Mills, D., Reeder, C., Wiliams, C., Jensen, K., Mills, J., Thompson, V. (2006). "Umatilla Agricultural Water Quality Management Area Plan." [Report: The Umatilla Local Advisory Committee]

Fontaine, T. A., \& Jacomino, V. M. F. (1997). "Sensitivity Analysis of Simulated Contaminated Sediment Transport". J. of the American Water Res.

Assoc., 33 (2).

Fung, F., Lopez, A., New, M. (2011). "Modelling the Impact of Climate Change on Water Resources". Chichester, West Sussex, UK: Wiley-Blackwell.

Gannett, M.W., Lite, K.E., Jr., Morgan, D.S., Collins, C.A. (2001). "Ground-Water Hydrology of the Upper Deschutes Basin, Oregon" - US Geological Survey Water Resources Investigations Report 00-4162.

Gephart, R.E., Arnett, R.C., Baca, R.G., Leonhart, L.S., Spane, F.A. (1979). "Hydrologic Studies within the Columbia Plateau, Washington - an Integration of Current Knowledge: Richland, Washington, Rockwell Hanford Operations, RHOBWI-ST-5". 
Gresswell, R. (1999). Fire and Aquatic Ecosystems in Forested Biomes of North America. Transactions of the American Fisheries Society, 128(2), 193-221.

Golmohammadi, G., Prasher, S., Madani, A., \& Rudra, R. (2014). Evaluating Three Hydrological Distributed Watershed Models: MIKE-SHE, APEX, SWAT.Hydrology, 1(1), 20-39.

Goncu, S., \& Albek, E. (2010). Modeling Climate Change Effects on Streams and Reservoirs with HSPF. Water Resources Management, 24(4), 707-726.

Gupta, H., Kling, H., Yilmaz, K., \& Martinez, G. (2009). Decomposition of the mean squared error and NSE performance criteria; implications for improving hydrological modelling. Journal of Hydrology, 377(1), 80-91.

Hamlet, A., \& Lettenmaier, D. (2007). Effects of 20th century warming and climate variability on flood risk in the western U.S. Water Resources Research, 43(6), Water Resources Research, 2007 Jun 28, Vol.43(6).

Hamlet, A.F., Carrasco, P., Deems, J., Elsner, M.M., Kamstra, T., Lee, C., Mauger, G., Salathe, E.P., Tohver, I., Whitely Binder, L. (2010). "Final Project Report for the Columbia Basin Climate Change Scenarios Project." $<$ http://www.hydro.washington.edu/2860/erport/>.

Hamlet, A. F. (2010). Assessing water resources adaptive capacity to climate change impacts in the Pacific Northwest Region of North America. Hydrology and Earth System Sciences Discussions, 7(4), 4437-4471.

A. F. Hamlet. (2011). Assessing water resources adaptive capacity to climate change impacts in the Pacific Northwest Region of North America. Hydrology and Earth System Sciences, 15(5), 1427-1443.

Hansen, A.J., Vaccaro, J.J., and Bauer, H.H. (1994) "Ground-Water Flow Simulation of the Columbia Plateau Regional Aquifer System, Washington, Oregon, and Idaho" - U.S. Geological Survey Water-Resources Investigations Report 91-4187.

Hay, L.E., Umemoto, M. (2006). "Multiple-Objective Stepwise Calibration Using LUCA: U.S. Geological Survey Open-File Report - 2006-1323."

Hills Area", Oregon and Washington: US Geological Survey Water-Resources Investigations Report 87-4268

Hay, L.E., Markstrom, S., and Ward-Garrison, C. (2011) "Watershed-Scale Response to Climate Change through the Twenty-First Century for Selected Basins across the United States". Earth Interact., 15, 1-37. 
Healy, R. W., and Scanlon, B.R. (2010). "Estimating Groundwater Recharge". Cambridge: Cambridge University Press.

Henderson, G., \& Golding, D. (1983). The effect of slash burning on the water repellency of forest soils at Vancouver, British Columbia. Canadian Journal of Forest Research, 13(2), 353-355.

Homer, C.G., Dewitz, J.A., Yang, L., Jin, S., Danielson, P., Xian, G., Coulston, J., Herold, N.D., Wickham, J.D., and Megown, K. (2015). Completion of the 2011 National Land Cover Database for the conterminous United States-Representing a decade of land cover change information. Photogrammetric Engineering and Remote Sensing, v. 81, no. 5, p. 345-354

Hooper, P. (1982) The Columbia River Basalts. Science (New York, NY), 215(4539), 1463-8.

Hooper, P. R. (1982). "The Columbia River Basalts". Science. 215 (4539): 14631468.

Hughes, M. (2008). Channel Change of the Upper Umatilla River during and between Flood Periods: Variability and Ecological Implications, ProQuest Dissertations and Theses.

Hutchinson, K., Christiansen, Daniel E., \& Geological Survey, issuing body. (2013). Use of the Soil and Water Assessment Tool (SWAT) for simulating hydrology and water quality in the Cedar River Basin, lowa, 2000-10 (Scientific investigations report ; 2013-5002). Reston, Virginia: U.S. Department of the Interior, U.S. Geological Survey.

Hyndman, \& Koehler. (2006). Another look at measures of forecast accuracy. International Journal of Forecasting, 22(4), 679-688.

Indian Forest Management Assessment Team. (2013). An Assessment of Indian forests and forest management in the United States. Portland, OR, Intertribal Timber Council Publication.

Jepsen, S., Molotch, N., Williams, M., Rittger, K., \& Sickman, J. (2012). Interannual variability of snowmelt in the Sierra Nevada and Rocky Mountains, United States: Examples from two alpine watersheds. Water Resources Research, 48(2), N/a.

Jones, K.L., Poole, G.C., Quaempts, E.J., O'Daniel, E., Beechie, T. (2008).

"Umatilla River Vision." [Report]. Retrieved September, 2013: http://ctuir.org/DNRUmatillaRiverVision.pdf 
Jung, II-W., and Heejun, C. (2011). "Assessment of future runoff trends under multiple climate change scenarios in the Willamette River Basin, Oregon, USA". Hydrological Processes. 25 (2)

Jung, I., \& Chang, W. (2011b). Climate change impacts on spatial patterns in drought risk in the Willamette River Basin, Oregon, USA. Theoretical and Applied Climatology, 108(3), 355-371.

Kahle, S.C., Morgan, D.S., Welch, W.B., Ely, D.M., Hinkle, S.R., Vaccaro, J.J., and Orzol, L.L. (2011). Hydrogeologic framework and hydrologic budget components of the Columbia Plateau Regional Aquifer System, Washington, Oregon, and Idaho: U.S. Geological Survey Scientific Investigations Report 2011-5124, $66 \mathrm{p}$.

Konrad, C. (2014). Simulated water-management alternatives using the Modular Modeling System for the Methow River basin, Washington (U.S. Geological Survey open-file report ; 2004-1051). Reston, Virgninia: U.S. Department of the Interior, U.S. Geological Survey.

Kundzewicz, Z. W., L. J. Mata, N. W. Arnell, P. Doll, P. “ Kabat, B. Jimenez, K. A. Miller, T. Oki, Z. SÍn, and 'I. A. Shiklomanov. (2007). Freshwater resources and their management. In Climate change 2007: Impacts, adaptation and vulnerability. Contribution of Working Group II to the Fourth Assessment Report of the Intergovernmental Panel on Climate Change, ed. M. L. Parry, O. F. Canziani, J. P. Palutikof, P. J. van der Linden, and C. E. Hanson, 173-210. Cambridge, UK: Cambridge University Press.

Knowles, N., Dettinger, M.D., Cayan, D.R. (2006). Trends in snowfall versus rainfall in the western United States. J. Clim. 19(18), 4545-4559.

Lambrechts, Thomas, François, Sébastien, Lutts, Stanley, Muñoz-Carpena, Rafael, \& Bielders, Charles L. (2014). Impact of plant growth and morphology and of sediment concentration on sediment retention efficiency of vegetative filter strips: Flume experiments and VFSMOD modeling. Journal of Hydrology, 511, 800-810.

Leavesley, G.H., Lichty, R.W., Troutman, B.M., and Saindon, L.G. (1983). "Precipitation Runoff Modeling System: User's Manual -Water-Resources Investigations Report 83-4238: US Geological Survey".

Leavesley, G.H., Restrepo, P.J., Markstrom, S.L., Dixon, M., and Stannard, L.G. (1996). The Modular Modeling System (MMS): User's manual: U.S. Geological Survey Open-File Report 96-151, 142 
Liang, X., D. P. Lettenmaier, E. F. Wood, and S. J. Burges, 1994: A Simple hydrologically Based Model of Land Surface Water and Energy Fluxes for GSMs, J. Geophys. Res., 99(D7), 14,415-14,428.

Letey, J., Elsenbeer, H, \& Robichaud, P. (2001). Causes and consequences of fire-induced soil water repellency. Hydrological Processes, 15(15), 2867-2875.

Lindberg, J.W. (1989). "A Numerical Study of Cooling Joint Width and Secondary Mineral Infilling in Four Grande Ronde Basalt Flows of the Central Columbia Platea, Washington", in, Reidel, S.P., and Hooper, P.R., eds., "Volcanism and Tectonism in the Columbia River Flood-Basalt Province" - Geological Society of America Special Paper, 239.

Lite, K.E., Jr., and Grondin, G.H. (1988). "Hydrogeology of the Basalt Aquifers near Mosier, Oregon - A Ground Water Resources Assessment: Oregon Department of Water Resources Ground Water Report", No. 33.

MacDonald, L., \& Huffman, E. (2004). Post-fire soil water repellency; persistence and soil moisture thresholds. Soil Science Society of America Journal, 68(5), 1729-1734.

Markstrom, S.L., Regan, R.S., Hay, L.E., Viger, R.J., Webb, R.M.T., Payn, R.A., and LaFontaine, J.H. (2015). PRMS-IV, the precipitation-runoff modeling system, version 4: U.S. Geological Survey Techniques and Methods, book 6, chap. B7, 158 p., http://dx.doi.org/10.3133/tm6B7.

Manga, M. (1997). "A Model for Discharge in Spring-Dominated Streams and Implications for the Transmissivity and Recharge of Quaternary Volcanics in the Oregon Cascades." Water Resources Res. (33:8).

Manga, M. (1999). "On the Timescales Characterizing Groundwater Discharge at Springs." J. Hydrology (219:1-2).

Markstrom, S. L., Hay, L. E., Ward-Garrison, D. C., Risley, J. C., Battaglin, W. A., Bjerklie, D. M., ... \& Walker, J. F. (2012). Integrated watershed-scale response to climate change for selected basins across the United States (No. 2011-5077, pp. i-143). US Geological Survey.

Markstrom, S.L., Niswonger, R.G., Regan, R.S. , Prudic, D.E., and Barlow, D.E. (2008). "GSFLOW - Coupled Ground-Water and Surface-Water Flow Model Based on the Integration of the Precipitation-Runoff Modeling System (PRMS) and the Modular Ground-Water Flow Model (MODFLOW-2005)." US Geological Survey Techniques and Methods 6-D1. 
Martin, D. A. and Moody, J. A. (2001), Comparison of soil infiltration rates in burned and unburned mountainous watersheds. Hydrol. Process., 15: 28932903

Mastin, M.C., Chase, K.J., and Dudley, R.W. (2011). "Changes in Spring Snowpack for Selected Basins in the United States for Different Climate-Change Scenarios". Earth Interact., 15, 1-18.

Mitchell, K., Lohmann, D., Houser, P., Wood, E., Schaake, J., Robock, A., . . . Bailey, A. (2004). The multi-institution North American Land Data Assimilation System (NLDAS): Utilizing multiple GCIP products and partners in a continental distributed hydrological modeling system. Journal of Geophysical Research: Atmospheres, 109(D7), N/a.

Moriasi, D.N., Arnold, J.G., Van Liew, M.W., Binger, R.L., Harmel, R.D., Veith, T.L.(2007). Model evaluation guidelines for systematic quantification of accuracy in watershed simulations. Transactions of the ASABE 50(3): 885-900.

Mote, P., Parson, W., Hamlet, E., Keeton, A., Lettenmaier, A., Mantua, F., Snover, N. (2003). Preparing for Climatic Change: The Water, Salmon, and Forests of the Pacific Northwest. Climatic Change, 61(1), 45-88.

Mote, Philip W., Hamlet, Alan F., Clark, Martyn P., \& Lettenmajer, Dennis P. (2005). Declining mountain snowpack in western North America.(Author Abstract). Bulletin of the American Meteorological Society, 86(1), 6.

Mote, P., Brekke, L., Duffy, P., \& Maurer, E. (2011). Guidelines for constructing climate scenarios. Eos, Transactions American Geophysical Union, 92(31), 257258.

Molotch, Fassnacht, Bales, \& Helfrich. (2004). Estimating the distribution of snow water equivalent and snow extent beneath cloud cover in the Salt-Verde River basin, Arizona. Hydrological Processes, 18(9), 1595-1611.

Moody, J. A., and Martin, D. A., 2001, Post-fire, rainfall intensity - peak discharge relations for three mountainous watersheds in the western USA: Hydrological Processes, v. 15, no. 15, p. 2981-2993

Muñoz-Carpena, Rafael, Parsons, John E., \& Gilliam, J.Wendell. (1999). Modeling hydrology and sediment transport in vegetative filter strips. Journal of Hydrology, 214(1), 111-129.

Nash, \& Sutcliffe. (1970). River flow forecasting through conceptual models part I - A discussion of principles. Journal of Hydrology, 10(3), 282-290. 
Neary, D.G., Ffolliott, P.F.(2005). The water resource: its importance, characteristics, and general response to fire. "In: Neary, D.G., Ryan, K.C., DeBano, L.F. (eds) Wildland rire in ecosystems: effects of fire on soil and water. General technical report RMRS-GTR-42. USDA Forest Service:pp 95-106.

Neitsch, S.L., Arnold, J.G., Kiniry, J.R. and Williams, J.R. (2011) Soil and Water Assessment Tool Theoretical Documentatio Version 2009. Texas Water Resources Institute Technical Report No. 406.

Newcomb, R.C. (1959). "Some Preliminary Notes on Ground Water in the Columbia River Basalt”. Northwest Science (33:1).

Newcomb, R.C. (1969). "Effect of Tectonic Structure on the Occurrence of Ground Water in the Basalt of the Columbia River Group of The Dalles Area", Oregon and Washington: U.S. Geological Survey Professional Paper 383-C.

Oberlander, P.L., and Miller, D.W. (1981). "Hydrologic Studies in the Umatilla Structural Basin - an Integration of Current Knowledge: Oregon Department of Water Resources", Unpublished Preliminary Report.

Oregon Water Resources Department. (1988). Umatilla Basin Report: State of Oregon, Salem, OR, $245 \mathrm{p}$.

Oris, F., Asselin, H., Ali, A., Finsinger, W., \& Bergeron, Y. (2014). Effect of increased fire activity on global warming in the boreal forest. 23(3), 206.

Oki, T., \& Kanae, S. (2006). Global hydrological cycles and world water resources. Science (New York, N.Y.), 313(5790), 1068-72.

Packard F.A., Hansen, A.J., Jr., Bauer, H.H. (1996) "Hydrogeology and Simulation of Flow and the Effects of Development Alternatives on the Basalt Aquifers of the Horse Heaven Hills, South-central Washington: US Geological Survey Water-Resources Investigations Report 94-4068".

Park, D., \& Markus, M. (2014). Analysis of a changing hydrologic flood regime using the Variable Infiltration Capacity model. Journal Of Hydrology, 515, $267-$ 280.

Pendleton Public Works Water Division. (2010). "City of Pendleton Water Management Conservation Plan".

P. Krause, D. P. Boyle, \& F. Bäse. (2005). Comparison of different efficiency criteria for hydrological model assessment. Advances in Geosciences, Vol 5, Pp 89-97 (2005), 89-97. 
Praskievicz, S., \& Chang, H. (2011). Impacts of Climate Change and Urban Development on Water Resources in the Tualatin River Basin, Oregon. Annals Of The Association Of American Geographers, 101(2), 249-271.

Psaris, Mike and Chang, Heejun (2014) "Assessing the Impacts of Climate Change, Urbanization, and Filter Strips on Water Quality Using SWAT," International Journal of Geospatial and Environmental Research: Vol. 1: No. 2, Article 1.

Qi, S., Sun, G., Wang, Y., Mcnulty, S., \& Myers, J. (2009). Streamflow Response to Climate and Landuse Changes in a Coastal Watershed in North Caroloina. Transactions Of The Asabe, 52(3), 739-749.

Raines, T., Miranda, Roger M., Texas Natural Resource Conservation Commission, Nueces River Authority, \& Geological Survey. (2002). Simulation of flow and water quality of the Arroyo Colorado, Texas, 1989-99 (Water-resources investigations report ; 02-4110). Austin, Tex. : Denver, CO: U.S. Dept. of the Interior, U.S. Geological Survey ; Branch of Information Services [distributor].

Reidel, S. P., T. L. Tolan, P. R. Hooper, M. H. Beeson, K. R. Fecht, R. D. Bentley, and J. L. Anderson, 1989b, "The Grande Ronde Basalt, Columbia River Basalt Group: Stratigraphic Descriptions and Correlations in Washington, Oregon, and Idaho, " in Volcanism and Tectonism in the Columbia River FloodBasalt Province", Special Paper 239, Geological Society of America Special Paper 239, pp. 21-53.

Reidel, S., \& Hooper, Peter R. (1989). Volcanism and tectonism in the Columbia River flood-basalt province (Special papers (Geological Society of America) ; 239). Boulder, Colo.: Geological Society of America.

Risley, J., Stonewall, A., Haluska, T. L. Oregon Department of Transportation, \& Geological Survey. (2008). Estimating flow-duration and low-flow frequency statistics for unregulated streams in Oregon (Scientific investigations report ; 2008-5126). Reston, Va.: U.S. Dept. of the Interior, U.S. Geological Survey.

Robichaud, P. R. 2005. Measurement of post-fire hillslope erosion to evaluate and model rehabilitation treatment effectiveness and recovery. International Journal of Wildland Fire, v. 14, no. 4, p. 475-485. 10.1071/.

Rulli, Maria Cristina, Bozzi, Silvia, Spada, Matteo, Bocchiola, Daniele, \& Rosso, Renzo. (2006). Rainfall simulations on a fire disturbed mediterranean area. Journal of Hydrology, 327(3), 323-338. 
Rulli, Maria Cristina, L. Offeddu, \& M. Santini. (2013). Modeling post-fire water erosion mitigation strategies. Hydrology and Earth System Sciences, 17(6), 23232337.

Rupp, D., Abatzoglou, J., Hegewisch, K., \& Mote, P. (2013). Evaluation of CMIP5 20 th century climate simulations for the Pacific Northwest USA. Journal of Geophysical Research: Atmospheres, 118(19), 10,884-10,906.

Sabol, M.A., and Downey, S.E. (1997). "Supporting Document for Consideration of the Eastern Columbia Plateau Aquifer System as a Sole Source Aquifer - U.S. Environmental Protection Agency, 910/R-97-002".

Safeeq, M., Grant, G., Lewis, S., \& Tague, C. (2013). Coupling snowpack and groundwater dynamics to interpret historical streamflow trends in the western United States. Hydrological Processes, 27(5), 655-668.

Sceva, J.E. (1996). A Brief Description of the Groundwater Conditions in the Ordinance Area, Morrow and Umatilla Counties, Oregon: State of Oregon, Water Resources Department.

Silbernagel, G., Nichols, D., Platt, N. (2013). “Umatilla Basin Water Quality Summary Water Year 2013" - Umatilla Basin Watershed Council. [Report]

Silins, U., Bladon, K., Kelly, E., Esch, E., Spence, J., Stone, M., . . Tichkowsky, I. (2014). Five-year legacy of wildfire and salvage logging impacts on nutrient runoff and aquatic plant, invertebrate, and fish productivity. Ecohydrology, 7(6), 1508-1523.

Singh, V., \& Frevert, Donald K. (2006). Watershed models. Boca Raton: Taylor \& Francis.

Soto, B., \& Díaz-Fierros, F. (1998). Runoff and soil erosion from areas of burnt scrub: Comparison of experimental results with those predicted by the WEPP model. Catena, 31(4), 257-270.

Spane, F., \& Webber, W. (1995). Hydrochemistry and hydrogeologic conditions within the Hanford Site upper basalt confined aquifer system. PNNL-10817.

Springer, J., Ludwig, R., Kienzle, S. (2015). Impacts of forest fires and climate variability in the hydrology of an alpine medium sized catchment in the Canadian Rocky Mountains. Hydrology, 2, 23-47. doi: 10.390/hydrology2010023

State of Oregon, Water Resources Department. "Report: Oregon's Integrated Water Resources Strategy." (2012). 
Steuer, J., Hunt, R. J, Middleton, Wisconsin. Department of Natural Resources, \& Geological Survey. (2001). Use of a watershed-modeling approach to assess hydrologic effects of urbanization, North Fork Pheasant Branch basin near Middleton, Wisconsin (Water-resources investigations report ; 01-4113). Middleton, Wis. : Denver, CO: U.S. Dept. of the Interior, U.S. Geological Survey ; Branch of Information Services [distributor].

Stewart, I. T., D. R. Cayan, and M. D. Dettinger (2005), Changes toward earlier streamflow timing across western North America, J. Clim., 18(8),1136 - 1155.

Surfleet, Christopher G., Tullos, Desirèe, Chang, Heejun, \& Jung, II-Won. (2012). Selection of hydrologic modeling approaches for climate change assessment: A comparison of model scale and structures. Journal of Hydrology, 464-465, 233248.

Terranova, O., Antronico, L., Coscarelli, R., \& laquinta, P. (2009). Soil erosion risk scenarios in the Mediterranean environment using RUSLE and GIS: An application model for Calabria (southern Italy). Geomorphology, 112(3), 228-245.

Tohver, I., Hamlet, A., \& Lee, S. (2014). Impacts of 21st-Century Climate Change on Hydrologic Extremes in the Pacific Northwest Region of North America. JAWRA Journal of the American Water Resources Association, 50(6), 1461-1476.

Tolan, T., Lindsey, K., Porcello, J. (2009) "A Summary of Columbia River Basalt Group Physical Geology and its Influence on the Hydrogeology of the Columbia River Basalt Aquifer System: Columbia Basin Ground Water Management Area of Adams, Franklin, Grant, and Lincoln Counties." [Report: Columbia Basin Ground Water Management Area]

Tolan, T.L., and Lite, K. (2008). "Geology and Hydrogeology of the Columbia River Basalt Group: A Field Trip Guide to Selected Localities in the Columbia River Gorge, Oregon"- Prepared for the National Ground Water Association International Conference in Nonrenewable Ground Water Resources Field Trip, October 15, 2008.

Tolan, T., Reidel, S., Beeson, M., Anderson, J., Fecht, K., \& Swanson, D. (1987). Revisions to the areal extent and volume of the Columbia River Basalt Group (CRBG). Abstracts with Programs - Geological Society of America, 19(6), 458.

Tsosie, R. (2004). "Climate Change, Sustainability and Globalization: Charting the Future of Indigenous Environmental Self-Determination." Environmental \& Energy Law \& Policy Journal 4.2: 188-255 
Turner, D., Conklin, D., \& Bolte, J. (2015). Projected climate change impacts on forest land cover and land use over the Willamette River Basin, Oregon, USA. Climate Change, 133(1), 335.

USDOE, US Department of Energy, (1988). "Site Characterization Plan, Reference Repository Location, Handford Site, Washington - Consultation Draft: Washington D.C., Office of Civilian Radioactive Waste Management, DOE/RW0164, V 1-9."

U.S. Forest Service (2001). Umatilla and Meacham Ecosystem Analysis. USDA Forest Service Pacific Northwest Region Umatilla National Forest. Pendleton, OR.

Vaccaro, J.J., Jones, M.A., Ely, D.M., Keys, M.E., Olsen, T.D., Welch, W.B., and Cox, S.E. (2009). "Hydrogeologic framework of the Yakima River basin aquifer system, Washington: U.S. Geological Survey Scientific Investigations Report 2009-5152".

Vaccaro, J., Olsen, Theresa D, United States. Bureau of Reclamation, Confederated Tribes Bands of the Yakama Nation, Washington, \& Geological Survey. (2007). Estimates of ground-water recharge to the Yakima River basin aquifer system, Washington, for predevelopment and current land-use and landcover conditions (Scientific investigations report ; 2007-5007). Reston, Va.: U.S. Geological Survey.

Vaccaro, J.J., 1999, Summary of the Columbia Plateau Regional Aquifer-System Analysis, Washington, Oregon, and Idaho: U.S. Geological Survey Professional Paper 1413-A, 51 p. (Also available at http://pubs.er.usgs.gov/usgspubs/pp/pp1413A.)

Vaccaro, J., Geological Survey, \& National Regional Aquifer Systems Analysis Program. (1986). Plan of study for the regional aquifer-system analysis, Columbia Plateau, Washington, northern Oregon, and northwestern Idaho. U.S. Dept. of the Interior, Geological Survey ;--Open-File Services Section, Western Distribution Branch, U.S. Geological Survey, distributor.

Vano, J., Nijssen, B., \& Lettenmaier, D. (2015). Seasonal hydrologic responses to climate change in the Pacific Northwest. Water Resources Research, 51(4), 1959-1976.

Van Vuuren, D., Edmonds, J., Kainuma, M., Riahi, K., Thomson, A., Hibbard, K., Rose, S. (2011). The representative concentration pathways: An overview. Climatic Change, 109(1-2), 5-31. 
Versini, P., Velasco, M., Cabello, A., \& Sempere-Torres, D. (2013). Hydrological impact of forest fires and climate change in a Mediterranean basin. Natural Hazards, 66(2), 609-628.

Vieira, Fernández, Vega, \& Keizer. (2015). Does soil burn severity affect the post-fire runoff and interrill erosion response? A review based on meta-analysis of field rainfall simulation data. Journal of Hydrology, 523, 452-464.

Viger, R. J., Hay, L. E., Markstrom, S. L., Jones, J. W., \& Buell, G. R. (2011). Hydrologic effects of urbanization and climate change on the Flint River Basin, Georgia. Earth Interactions, 15(20), 1-25.

Vynee, Stacy, Reder, B., Hamilton, R., Doppelt, B., Dello, K., Sharp, D. (2010) "Projected Future Conditions in the Umatilla River Basin of Northeast Oregon." [Report:

Oregon Climate Change Research Institute, Climate Leadership Initiative Institute for a Sustainable Environment, University of Oregon].

Waibel, S.M. (2011). "Model analysis of the hydrologic response to climate change in the Upper Deschutes Basin, Oregon, Thesis". Portland, Or: Portland State University. Retrieved from: http://archives.pdx.edu/ds/psu/6941.

Waibel, M.S., Gannett, M.W., Chang, H., and Hulbe, C.L. (2013). "Spatial Variablity of the Response to Climate Change in Regional Groundwater Systems - Examples from Simulations in the Deschutes Basin, Oregon." J. of Hydrology (486).

Wallulis and Associates (1995). Draft of the Water System Master Plan for the City of Pendleton, Oregon.

Wozniak, K.C. (1995). "Hydrogeology, in, Hydrogeology, Groundwater Chemistry, and Land Uses in the Lower Umatilla Basin Groundwater Management Area, Northern Morrow and Umatilla Counties, Oregon." Report: [Final Review Draft: Salem, Oregon, Oregon Department of Environmental Quality] 
APPENDIX A: Summary of Statistical Analyses Comparing Key Climate Indices Before Forest Cover Reduction

\begin{tabular}{|c|c|c|c|c|c|c|c|}
\hline \multicolumn{8}{|c|}{ Calculated p-values in RCP 4.5} \\
\hline & $\begin{array}{c}\text { 1980s } \\
\text { vs. } \\
2020 s\end{array}$ & $\begin{array}{c}1980 s \\
\text { vs. } \\
2050 \text { s }\end{array}$ & $\begin{array}{c}1980 \mathrm{~s} \\
\text { vs. } \\
2080 \mathrm{~s}\end{array}$ & $\begin{array}{c}\text { 2020s } \\
\text { vs. } \\
2050 s\end{array}$ & $\begin{array}{c}2020 \text { s } \\
\text { vs. } \\
2080 \text { s }\end{array}$ & $\begin{array}{c}2050 s \\
\text { vs. } \\
2080 s\end{array}$ & Test \\
\hline $\begin{array}{l}\text { Basin } \\
\text { Runoff }\end{array}$ & -- & -- & -- & -- & -- & -- & $9.78 \mathrm{E}-01^{*}$ \\
\hline Mean CT & -- & -- & -- & -- & -- & -- & $2.52 \mathrm{E}-01^{*}$ \\
\hline $\begin{array}{l}\text { Winter } \\
\text { Flows }\end{array}$ & 0.00 & 0.00 & 0.00 & 0.00 & 0.00 & $\begin{array}{c}\text { 6.87E- } \\
01\end{array}$ & 2.20E-16* \\
\hline $\begin{array}{c}\text { Summer } \\
\text { Flows }\end{array}$ & 0.00 & 0.00 & 0.00 & $\begin{array}{c}3.38 \mathrm{E}- \\
03\end{array}$ & $\begin{array}{c}\text { 1.81E- } \\
05\end{array}$ & $\begin{array}{c}4.92 \mathrm{E}- \\
01\end{array}$ & $2.20 \mathrm{E}-16^{*}$ \\
\hline SWE/P & $\begin{array}{c}(254.12 \\
74.04)\end{array}$ & $\begin{array}{c}(400.62 \\
74.04)\end{array}$ & $\begin{array}{c}(511.09, \\
74.66)\end{array}$ & $\begin{array}{c}(146.50, \\
73.42)\end{array}$ & $\begin{array}{c}(256.97 \\
74.04)\end{array}$ & $\begin{array}{c}(110.48, \\
74.04)\end{array}$ & $2.20 \mathrm{E}-16^{\star *}$ \\
\hline $\begin{array}{c}\text { Basin } \\
\text { Recharge }\end{array}$ & $\begin{array}{l}\text { (50.00, } \\
74.041)\end{array}$ & $\begin{array}{l}\text { (59.97, } \\
74.04) \\
\end{array}$ & $\begin{array}{c}(134.44, \\
74.66) \\
\end{array}$ & $\begin{array}{l}\text { (9.97, } \\
\text { 73.41) } \\
\end{array}$ & $\begin{array}{l}\text { (84.43, } \\
74.04) \\
\end{array}$ & $\begin{array}{l}\text { (74.46, } \\
74.04) \\
\end{array}$ & $3.90 \mathrm{E}-05^{\star \star}$ \\
\hline \multicolumn{8}{|c|}{ Calculated p-values in RCP 8.5} \\
\hline $\begin{array}{l}\text { Basin } \\
\text { Runoff }\end{array}$ & -- & -- & -- & -- & -- & -- & $3.60 \mathrm{E}-01^{*}$ \\
\hline Mean CT & -- & -- & -- & -- & -- & -- & $9.78 \mathrm{E}-01^{*}$ \\
\hline $\begin{array}{l}\text { Winter } \\
\text { Flows }\end{array}$ & 0.00 & 0.00 & 0.00 & $\begin{array}{c}8.90 \mathrm{E}- \\
06\end{array}$ & 0.00 & $\begin{array}{c}\text { 2.11E- } \\
04\end{array}$ & $2.20 \mathrm{E}-16^{\star}$ \\
\hline $\begin{array}{l}\text { Summer } \\
\text { Flows }\end{array}$ & $\begin{array}{l}\text { (35.34, } \\
23.50)\end{array}$ & $\begin{array}{c}(55.01 \\
23.5)\end{array}$ & $\begin{array}{l}(80.17 \\
23.70)\end{array}$ & $\begin{array}{l}(19.67 \\
23.30)\end{array}$ & $\begin{array}{c}(44.83, \\
23.50)\end{array}$ & $\begin{array}{l}(25.17 \\
23.50)\end{array}$ & $2.20 \mathrm{E}-16^{\star *}$ \\
\hline SWE/P & $\begin{array}{c}(230.97 \\
74.04)\end{array}$ & $\begin{array}{c}(425.31 \\
74.04)\end{array}$ & $\begin{array}{c}(662.39 \\
74.66)\end{array}$ & $\begin{array}{c}(194.34, \\
73.41)\end{array}$ & $\begin{array}{c}(431.43, \\
74.04)\end{array}$ & $\begin{array}{c}(237.09 \\
74.04)\end{array}$ & $2.20 \mathrm{E}-16^{\star \star}$ \\
\hline $\begin{array}{c}\text { Basin } \\
\text { Recharge }\end{array}$ & $\begin{array}{l}\text { (60.91, } \\
74.041)\end{array}$ & $\begin{array}{l}(96.48, \\
74.04)\end{array}$ & $\begin{array}{c}(176.17, \\
74.66)\end{array}$ & $\begin{array}{c}(35.57 \\
73.41)\end{array}$ & $\begin{array}{c}(115.27, \\
74.04)\end{array}$ & $\begin{array}{c}(79.69 \\
74.04)\end{array}$ & 7.91E-09** \\
\hline
\end{tabular}

${ }^{*}$ ANOVA

${ }^{*}$ Kruskal-Wallis 
APPENDIX B: Summary of Statistical Analyses Comparing Key Climate Indices After Forest Cover Reduction

\begin{tabular}{|c|c|c|c|c|c|}
\hline \multicolumn{6}{|c|}{ Calculated p-values in the RCP 8.5 Scenario } \\
\hline Index & GCM Model & $\begin{array}{l}\text { Hist. vs. } \\
\text { Before } \\
\text { LCC }\end{array}$ & $\begin{array}{l}\text { Hist. vs. } \\
\text { After LCC }\end{array}$ & $\begin{array}{l}\text { Before LCC } \\
\text { vs. After } \\
\text { LCC }\end{array}$ & Test \\
\hline \multirow{2}{*}{ Mean CT } & MIROC5 & 0.00 & 0.00 & $3.66 \mathrm{E}-01$ & $2.20 \mathrm{E}-16^{*}$ \\
\hline & HadGEM2-ES & 0.00 & 0.00 & $5.29 \mathrm{E}-01$ & $8.15 \mathrm{E}-16^{*}$ \\
\hline \multirow[t]{2}{*}{ Winter Flows } & MIROC5 & 0.00 & 0.00 & $6.36 \mathrm{E}-01$ & $6.49 \mathrm{E}-12^{*}$ \\
\hline & HadGEM2-ES & 3.37E-04 & 3.71E-05 & $8.22 \mathrm{E}-01$ & $9.88 \mathrm{E}-06^{*}$ \\
\hline \multirow[t]{2}{*}{ Summer Flows } & MIROC5 & 0.00 & 0.00 & $9.99 \mathrm{E}-01$ & $2.04 \mathrm{E}-10^{*}$ \\
\hline & HadGEM2-ES & -- & -- & -- & $4.80 \mathrm{E}-01^{* *}$ \\
\hline \multirow[t]{2}{*}{$\begin{array}{l}\text { Basing } \\
\text { Recharge }\end{array}$} & MIROC5 & -- & -- & -- & $3.78 \mathrm{E}-01^{*}$ \\
\hline & HadGEM2-ES & 2.03E-03 & $3.26 \mathrm{E}-01$ & $1.01 \mathrm{E}-01$ & $2.95 \mathrm{E}-03^{*}$ \\
\hline \multirow[t]{2}{*}{ SWE/P } & MIROC5 & $\begin{array}{c}(35.49, \\
19.75)\end{array}$ & $\begin{array}{l}(41.13, \\
19.75)\end{array}$ & $(5.63,19.58)$ & 3.17E-10** \\
\hline & HadGEM2-ES & $\begin{array}{c}(42.52, \\
19.47)\end{array}$ & $\begin{array}{c}\text { (43.45, } \\
\text { 19.47) }\end{array}$ & $\begin{array}{l}0.93 \\
19.471)\end{array}$ & 3.39E-14** \\
\hline
\end{tabular}

${ }^{*}$ ANOVA

${ }^{* *}$ Kruskal-Wallis 
APPENDIX C: Comparison of Model Performance

\begin{tabular}{|l|r|r|r|r|r|r|}
\hline & \multicolumn{3}{|c|}{ Precipitation (cm) } & \multicolumn{3}{|c|}{ Temperature $\left(^{\circ} \mathbf{C}\right)$} \\
\hline GCM Model & $\mu$ Obs. & $\mu$ Exp. & $\begin{array}{l}\text { Obs- } \\
\text { Exp }\end{array}$ & $\mu$ Obs. & $\mu$ Exp. & $\begin{array}{l}\text { Obs- } \\
\text { Exp }\end{array}$ \\
\hline BCC-CSM1.1 & 1.80 & 1.78 & 0.01 & 60.94 & 58.35 & 2.59 \\
\hline CanESM2 & 1.80 & 1.78 & 0.01 & 60.99 & 58.35 & 2.64 \\
\hline CNRM-CM5 & 1.79 & 1.78 & 0.01 & 60.99 & 58.35 & 2.64 \\
\hline CSIRO-Mk3.6.0 & 1.80 & 1.78 & 0.01 & 60.11 & 58.35 & 1.76 \\
\hline GFDL-ESM2M & 1.79 & 1.78 & 0.01 & 60.62 & 58.35 & 2.27 \\
\hline HadGEM2-ES & 1.79 & 1.78 & 0.01 & 60.64 & 58.35 & 2.29 \\
\hline INM-CM4 & 1.80 & 1.78 & 0.01 & 60.98 & 58.35 & 2.63 \\
\hline MIROC5 & 1.80 & 1.78 & 0.02 & 59.81 & 58.35 & 1.46 \\
\hline MRI-CGCM3 & 1.80 & 1.78 & 0.01 & 60.71 & 58.35 & 2.35 \\
\hline NorESM1-M & 1.79 & 1.78 & 0.01 & 60.60 & 58.35 & 2.25 \\
\hline
\end{tabular}

